\title{
Coordination of Anions by Noncovalently Bonded $\sigma$-Hole Ligands
}

\author{
Steve Scheiner*1, Mariusz Michalczyk, ${ }^{2}$ and Wiktor Zierkiewicz, ${ }^{* 2}$ \\ ${ }^{1}$ Department of Chemistry and Biochemistry, Utah State University Logan, Utah 84322-0300, \\ United States \\ ${ }^{2}$ Faculty of Chemistry, Wrocław University of Science and Technology, Wybrzeże Wyspiańskiego \\ 27, 50-370 Wrocław, Poland \\ *Correspondence to: steve.scheiner@usu.edu; wiktor.zierkiewicz@pwr.edu.pl
}

\begin{abstract}
Research on $\sigma$-hole interactions that include halogen, chalcogen, pnicogen, and tetrel bonding has been accelerating in recent years. These cousins of the $\mathrm{H}$-bond have many similar properties, including geometric preferences and energetics. Most of the work to date has focused on neutral complexes, with less known about these bonds to anions. This review summarizes the current state of knowledge about the complexes of anions with ligands that engage in these sorts of noncovalent bonds. Of particular interest are comparisons with $\mathrm{H}$-bonds, and how the geometry of the fully coordinated complex varies as the number of surrounding ligands increases. A specific application of these ideas is explored in which these noncovalent bonds can be used to selectively bind certain anions in a multidentate arrangement, where a symbiotic interplay of experimental and computational methods has provided some useful insights.
\end{abstract}

keywords: halogen bond; chalcogen bond; pnicogen bond; tetrel bond; H-bond 


\section{INTRODUCTION}

II. ANIONS BOUND BY H-BONDS

III. GENERAL FEATURES OF NONCOVALENT BONDS

IV. NONCOVALENT INTERACTIONS WITH A SINGLE LIGAND

V. MULTIPLE LIGANDS

1. Background

2. Detailed Systematic Calculations

3. Clustering around Diatomic Anions

$\mathrm{n}=2$

$\mathrm{n}=3$

$\mathrm{n}=4$

VI. MULTIPLY COORDINATED ANION RECEPTORS

1. Experimental Developments

2. Computational Exploration

VII. PROSPECTS 


\section{INTRODUCTION}

The purpose of this review is an exploration of the current state of knowledge concerning the way in which anions are coordinated by various numbers of different ligands. The focus lies with ligands which bind to the anion with the aid of noncovalent bonds. In particular, these noncovalent bonds are close cousins of H-bonds (HBs), but the bridging proton is replaced by atoms from the right side of the periodic table. Depending upon the specific column from which this substitute bridging atom is drawn, these bonds are commonly known as halogen, chalcogen, pnicogen, and tetrel bonds. (The abbreviations that will be used for these noncovalent bonds are respectively $\mathrm{XB}, \mathrm{YB}, \mathrm{ZB}$, and $\mathrm{TB}$.)

Because of their close similarity to HBs, this review begins with a very brief summary of a vast literature of anions within a surrounding atmosphere of one or more $\mathrm{H}$-bonding ligands, which will set up the background by which to understand the other, and perhaps more interesting, noncovalent bonding ligands. This outline is followed by a quick overview of the general features of these noncovalent cousins of HBs, in particular the nature and strength of their bonding, and the fundamental features that lead to certain preferred geometries. The review then turns to a discussion of what has been learned to this point about the interactions of an anion to a single ligand, on which rests an understanding of the interactions with multiple ligands. In fact, work dealing with a situation wherein an anion is surrounded by more than one ligand of this type remains in its early stages, and the next section summarizes what is presently known on this score. This section is organized into two parts: The first deals with a monatomic anion, and the second section concerns itself with various diatomic or larger anions.

Following the preceding discussion of the fundamentals of the coordination of anions by these noncovalently bonding ligands, the review turns to a specific related problem as an instructional exercise. As understanding of halogen and related bonds has developed, so too has the interest in applying this idea to a practical purpose, the design a new class of anion receptors. The goal is the development of a new set of molecules that bind an anion by a number of noncovalent bonds, in a sort of cage structure. It is hoped that the incorporation of the fundamental ideas about these bonds will enable receptors to be constructed that not only bind the anion strongly, but also selectively, picking one anion in particular out of a soup containing many. Work on this problem has been double-pronged, with computations coming together with experimental approaches, and the two guiding one another.

\section{ANIONS BOUND BY H-BONDS}

Because of the basic similarities between HBs and the spectrum of related noncovalent bonds, it might be helpful to begin with a very brief outline of the most important aspects of the coordination of anions by H-bonding ligands. This summary can provide a point of contact with the later discussion of $\mathrm{XB}, \mathrm{YB}, \mathrm{ZB}$, and $\mathrm{TB}$ coordination. The overview focuses on work that has appeared in the literature over the last five years [1-28]. A good deal of the work has involved complexes of monoatomic anions (i.e. $\mathrm{F}^{-}, \mathrm{Cl}^{-}$) with a single ligand, stabilized by one or more HBs $[2,6,10,13,15,16,23,25,26]$. The binding energies for each of these anions, comprising the halides and $\mathrm{Au}^{-}$, combined with a series of proton donating ligands, are 
summarized in the upper portion of Table 1. (In some indicated cases, the quantity reported is the interaction energy, which differs from the binding energy by the internal deformation energies associated with the morphing of the geometry of each monomer from its optimized structure to that adopted within the complex. This quantity is alternately referred to as reorganization energy.) These quantities extend over a wide range from a few $\mathrm{kcal} / \mathrm{mol}$ (e.g. 2.9 $\mathrm{kcal} / \mathrm{mol}$ for the complex of the Au anion with methane [6]) up to $70.0 \mathrm{kcal} / \mathrm{mol}$ in the doubly $\mathrm{H}$ bonded chloride with squaramide [23] or even $200 \mathrm{kcal} / \mathrm{mol}$ as for the $\left[\mathrm{Co}\left(\mathrm{NH}_{3}\right)_{5} \mathrm{NO}_{2}\right] \mathrm{Cl}^{+}$ complex (where the $\mathrm{Cl}^{-}$is bonded through three $\mathrm{HBs}$ to the cationic ligand [2]). In general, the binding energies are reduced as the anion grows in size, although there are certainly exceptions. There are also substantial data for $\mathrm{H}$-bonding of polyatomic anions (i.e. $\mathrm{NO}_{3}{ }^{-}, \mathrm{OH}^{-}, \mathrm{CH}_{3} \mathrm{COO}^{-}$, $\left.\mathrm{HPO}_{4}{ }^{2-}\right)[2,5,6,11,16,17,20,22,28]$. The binding energies are typically in the range between about 10 and $30 \mathrm{kcal} / \mathrm{mol}$, as reported in the lower section of Table 1.

The binding of an anion to more than one ligand presents interesting questions of preferred geometry, as well as energetics. The case of a pair of ligands is probably the most studied [3, 12, $14,19,21,27]$. One might expect that those two ligands ought to lie directly opposite one another on either side of the anion but this supposition is not borne out by calculations. For example, halide anions with two $\mathrm{H}_{2}$ ligands[12] are slightly bent as when $\mathrm{F}^{-}$is surrounded by two water ligands $[3,19]$. Even greater deviation from linearity (about 109') was found when $\mathrm{Cl}^{-}$is surrounded by $\mathrm{HF}$ or $\mathrm{HCl}$ ligands [27], also the case in the $\mathrm{F}^{-} \ldots(\mathrm{HF})_{2}$ complex [14]. Note that three HF molecules take up positions on an equilateral triangle, and four occupy vertices of a tetrahedron. The situation becomes a bit more complicated when two ligands surround a polyatomic anion. As one example, the complex of carbonate anion plus two water molecules takes up a geometry wherein each water engages in two O $\cdots \mathrm{H}$ HBs [3]. A set of complexes between polyatomic anions like $\mathrm{OH}^{-}, \mathrm{NH}_{2}^{-}, \mathrm{NO}_{2}^{-}, \mathrm{CN}^{-}, \mathrm{ClO}^{-}$plus two $\mathrm{H}_{2}$ ligands has been investigated by Della and Suresh [12]. They calculated that the total interaction energy is about twice that calculated for one ligand complex, i.e. little cooperativity, and that the binding energy follows the order $\mathrm{OH}^{-}>\mathrm{NH}_{2}^{-}>\mathrm{ClO}^{-}>\mathrm{NO}_{2}^{-}>\mathrm{CN}^{-}$. The literature also contains evidence of clustering of the noble metal anion $\mathrm{Au}_{2}^{-}$with two water or methanol molecules [21], for which the binding energies with water $(-24.44 \mathrm{kcal} / \mathrm{mol})$ were larger than with methanol $(-19.42$ $\mathrm{kcal} / \mathrm{mol})$.

Anionic complexes with more than two ligands $(n=3$ or $n=4)$ have also been considered [1, $3,9,12,14,19]$. For $n=3$, monoatomic anions tend to form trigonal planar or pyramidal clusters, which changes to tetrahedral upon addition of a fourth ligand [3, 12, 14, 19, 27]. Not unexpectedly, increasing the number of ligands raises the total binding energy. Negative cooperativity, decreasing the average binding energy with larger number of ligands was observed by Kucherov et al. [14]. A larger number of ligands $(n=5$ and $n=6)$ yields trigonal bipyramidal and octahedral arrangement, respectively $[12,14]$ (see Fig. 1). A trigonal pyramid geometry was obtained when all ligands interact with one and the same atom [1,12] of a polyatomic anion. When the ligands are bounded to more than one atom, for instance $\mathrm{CO}_{3}{ }^{2-}$ or $\mathrm{NO}_{2}{ }^{-}$the cluster takes on another shape $[1,3,12]$. It has been found that for four $\mathrm{H}_{2}$ ligands the $\mathrm{OH}^{-}, \mathrm{NH}_{2}^{-}, \mathrm{ClO}^{-}$ anions form a square pyramid [12].

\section{GENERAL FEATURES OF NONCOVALENT BONDS}

One begins with a few fundamental issues concerning these sorts of bonds that have a great deal of impact on their clustering around anions or any other nucleophile. The angular 
preferences can be largely understood on the basis of electrostatics. A nucleophile is likely to be attracted, at least to a first approximation, by a region of positive electrostatic potential on the partner molecule. The location of this region can be understood by consideration of two principles. In the first place, the atom of interest, whether halogen, chalcogen, pnicogen, or tetrel, will be engaged in a covalent bond with an electron-withdrawing substituent. The molecules in Fig. 2 take $\mathrm{F}$ as this substituent. The $\sigma(\mathrm{F}-\mathrm{A})$ orbital of this covalent bond will draw some of A's electron density toward it, leaving a depletion along the extension of the F-A axis. This reduction of density amounts to what is commonly termed a $\sigma$-hole. In this same location, there exists the antibonding $\sigma^{*}(\mathrm{~F}-\mathrm{A})$ orbital which is empty of electrons. Importantly, this empty orbital can serve as a natural place into which the approaching nucleophile can transfer some of its electron density, an important component in the strength of the interaction, which imparts to it what may be called partial covalent character. This $\sigma^{*}$ orbital is indicated by the light blue regions in Fig. 2, each directly opposite the F-A bond.

The second factor is associated with the lone pairs on each A atom. There are no such lone pairs on the T atom, as in Fig. 2a, so the most positive region of the MEP, indicated by the blue region, is coincident with the $\sigma^{*}$ orbital. The pnicogen atom, on the other hand, contains a single lone pair, represented by the red lobe in Fig. 2b. The attendant negative potential associated with this density pushes the positive region of the MEP down away from itself, as is evident in the figure. Consequently, a nucleophile attracted to this region is located a certain angle away from the F-P axis, and a ZB would be expected to have a $\theta(\mathrm{F}-\mathrm{Z} \cdot \mathrm{Nuc})$ angle less than $180^{\circ}$. The displacement of the nucleophile from the $\sigma^{*}$ orbital will reduce the interorbital overlap with the nucleophile, and has a weakening effect on the ZB. The two lone pairs of a chalcogen atom, as in Fig. 2c, have a similar, and even stronger, effect of pushing the positive MEP down away from the F-Y axis. In fact, in this particular FSH molecule, the most positive MEP is associated with the $\mathrm{H}$ atom so a $\mathrm{SH}^{\cdots} \mathrm{Nuc} \mathrm{HB}$ can be expected, as an alternative to a potential chalcogen bond. In the case of three lone pairs on the $\mathrm{X}$ atom, their symmetry places the positive MEP back up along the F-X axis, collinear with the $\sigma^{*}$ orbital, which explains the linearity of XBs. As in the case of TBs, this collinearity maximizes the interorbital overlap with the nucleophile, helping to strengthen the XB.

As for the strength of these noncovalent bonds, they are sensitive to the intensity of the $\sigma$ hole as a principal factor. Such a hole is dependent upon the ability of the substituent, F in Fig. 2 , to draw density toward itself. So these bonds are strengthened as the substituent becomes more electron-withdrawing. The number of electron-withdrawing substituents is an issue as well, as more of them will further enhance the intensity of the $\sigma$-hole, even if they do not lie directly opposite this hole. Second, as one goes down a column of the periodic table, the A atom becomes more electropositive which will enhance the intensity of the positive region. A second issue is the increasing polarizability, which will allow more density to be drawn away from the $\sigma$-hole region, again making it more positive. It is for these reasons that atoms from the first row of the periodic table, i.e. F, O, N, and C, are reluctant participants in these sorts of bonds. They do form these bonds, but they are generally quite weak. And of course, the strength of the bond 
will be highly dependent on the basicity of the nucleophile, which both interacts with the positive MEP of the Lewis acid and donates charge to its $\sigma^{*}$ orbital. Charge on either subunit amplifies the interaction whether an anionic nucleophile, as discussed below, or a positive charge on the Lewis acid [29-31].

It would be a mistake to equate the strength of any of these bonds with only the intensity of the $\sigma$-hole. There are other factors which add in, most notably charge transfer and dispersion, which can make comparable contributions, and which do not necessarily obey the same trends. As for magnitudes, these bonds run a wide gamut, from only 1 or $2 \mathrm{kcal} / \mathrm{mol}$, up to $100 \mathrm{kcal} / \mathrm{mol}$ or more. There does not seem to be any rule that has yet been elucidated that places one sort of bond, say a XB, as uniformly stronger than any of the others. But it is emphasized at the outset that these bonds are quite comparable in strength to the venerable $\mathrm{H}$-bond, and can be quite a bit stronger.

\section{NONCOVALENT INTERACTIONS WITH A SINGLE LIGAND}

As a prelude to considering the clustering of ligands around an anion, it would be worthwhile to first review what has been learned over the last few years concerning the interactions of anions with a single molecule. There is a great deal of evidence to support the supposition that an anion will engage in a considerably stronger noncovalent bond than will an equivalent neutral molecule. This idea is already widely accepted for HBs, so there is no reason to believe it will not be equally true for other related bonds. For example, $\mathrm{Br}^{-}$and $\mathrm{CN}^{-}$were the targets of binding by a series of bromocarbons [32] via a XB. In a forerunner of succeeding calculations, the binding was attributed only in part to formal Coulombic attraction, supplemented by very substantial contributions from charge transfer and other interorbital interactions. The $\mathrm{Br}-$ containing molecules were rather diverse, including alkanes, alkenes, and alkynes as well as aromatic systems, with and without F-substitution. Interaction energies varied from as small as 1 $\mathrm{kcal} / \mathrm{mol}$ for $\mathrm{CH}_{3} \mathrm{Br}$ up to $14 \mathrm{kcal} / \mathrm{mol}$ for its $\mathrm{CF}_{3} \mathrm{Br}$ perfluorosubstituted analogues. Binding to the $\mathrm{C}$ atom of $\mathrm{CN}^{-}$was somewhat stronger than to the $\mathrm{Br}^{-}$. In common with $\mathrm{H}$-bond donors, the binding strength varied along the $\mathrm{sp}^{3}<\mathrm{sp}^{2}<\mathrm{sp}$ sequence.

Del Bene et al [33] diversified the sample by examination of both the halogen and tetrel bonds that the halides can form with a family of simple substituted methanes, and compared their data to HBs. They found HBs the strongest, followed by TB and then by XB as the weakest. However, most of these bonds were fairly strong in any case. The tetrel bond between $\mathrm{H}_{3} \mathrm{FC}$ and $\mathrm{F}^{-}$amounted to some $13 \mathrm{kcal} / \mathrm{mol}$, and the $\mathrm{H}_{3} \mathrm{ClC} \cdots \mathrm{Cl}^{-}$analogue was only slightly weaker at 11 $\mathrm{kcal} / \mathrm{mol}$. Rotating the molecule around leads to a $\mathrm{XB}$, but the binding energy of this interaction for $\mathrm{H}_{3} \mathrm{CCl} \cdots \mathrm{Cl}^{-}$is considerably weaker, and in fact slightly repulsive. In contrast the $\mathrm{HB}$ energy for $\mathrm{F}_{3} \mathrm{CH} \cdots \mathrm{F}^{-}$is $27 \mathrm{kcal} / \mathrm{mol}$. Along similar lines, halides were paired with a series of dihalomethanes $\mathrm{H}_{2} \mathrm{XC}-\mathrm{X}$ and studied by single-crystal X-ray diffraction, followed by DFT calculations [34]. The computed binding energies confirmed $\mathrm{Br}$ to be a stronger $\mathrm{XB}$ donor than $\mathrm{Cl}$ by a factor of roughly 2, whereas $\mathrm{Cl}^{-}$engages in slightly stronger $\mathrm{XBs}$ than does $\mathrm{Br}^{-}$. Fig. 3 
confirms the ability of calculations on the right to reasonably mimic experimental geometries on the left.

The general case of anion binding, viz. $\mathrm{Cl}^{-}$and $\mathrm{Br}^{-}$, via halogen, chalcogen, or pnicogen bonding was evaluated in 2013 [35] with an eye toward identification of the most accurate computational method. The results pointed toward M06-2X as an excellent DFT choice, particularly for the anions involved in halogen and chalcogen bonds. The two smaller halides were placed within chalcogen bonding situations [36], and again $\mathrm{F}^{-}$bound more strongly than its larger $\mathrm{Cl}^{-}$cousin, reaching up to $55 \mathrm{kcal} / \mathrm{mol}$ when bound to $\mathrm{S}(\mathrm{CN})_{2}$. The strong chalcogen bonding to halides and other anions was confirmed by experimental measurements [37] which placed binding enthalpies in the $20 \mathrm{kcal} / \mathrm{mol}$ range. Also with respect to chalcogen bonds, a set of pyrylium cations and thio-, seleno- and telluro- analogues were paired [38] with $\mathrm{Cl}^{-}$as well as the larger anions $\mathrm{NO}_{3}{ }^{-}$and $\mathrm{BF}_{4}^{-}$. These ion-pair complexes, some of which with $\mathrm{Cl}^{-}$are pictured in Fig. 4, had particularly large interaction energies, exceeding $100 \mathrm{kcal} / \mathrm{mol} \mathrm{CN}^{-}$and $\mathrm{YCN}^{-}$ ( $\mathrm{Y}=\mathrm{O}, \mathrm{S}, \mathrm{Se}, \mathrm{Te}$ ) anions engaged in complexes with 1,2,5-chalcogenadiazoles [39] and were studied experimentally and computationally. Interaction energies in the $37-52 \mathrm{kcal} / \mathrm{mol}$ were obtained [40]. A wide range of anions from monatomic halides, to diatomic $\mathrm{CN}^{-}, \mathrm{OH}^{-}$, and $\mathrm{SH}^{-}$ and triatomics like $\mathrm{N}_{3}{ }^{-}, \mathrm{SCN}^{-}$all interact with $\mathrm{KrO}_{3}, \mathrm{XeO}_{3}$, and $\mathrm{XeOF}_{2}$ [41] with interaction energies as large as $15 \mathrm{kcal} / \mathrm{mol}$. Anions such as the halides have also been studied when interacting with a radical such as $\mathrm{PO}_{2}$ [42]. The interactions can occur through either a $\sigma$ or $\pi$ hole on the central $\mathrm{P}$ atom, the former being a bit stronger.

Tetrel bonds have attracted a great deal of attention in recent years, including such bonds to anions. $\mathrm{CF}_{4}$ interacts with $\mathrm{F}^{-}$via a tetrel bond with a binding energy of $6.5 \mathrm{kcal} / \mathrm{mol} ; \mathrm{FCH}_{3}$ is even stronger at $14 \mathrm{kcal} / \mathrm{mol}$. These quantities are considerably larger than for the corresponding halogen bonds. Tetrel bonds can also form by $\mathrm{H}_{3} \mathrm{FT}$ with $\mathrm{N}_{3}{ }^{-}, \mathrm{OCN}^{-}$and $\mathrm{SCN}^{-}$anions [43]. Again, these tetrel bonds can be rather strong, varying between 8 and $50 \mathrm{kcal} / \mathrm{mol}$. This sort of tetrel bond, in this case to the carboxylate anionic group of an aspartate residue, can have important biological implications [44]. Tetrel bonds to anions were studied extensively for halides, as well as $\mathrm{CN}^{-}, \mathrm{N}_{3}{ }^{-}$, and $\mathrm{SCN}^{-}$. The interaction energies span a large range, from 1.7 to $84 \mathrm{kcal} / \mathrm{mol}$ in in $(\mathrm{CN}) \mathrm{F}_{3} \mathrm{Si}^{*} \cdot \mathrm{F}^{-}[45]$. Later expansion of the system considered [46] led to a higher upper limit of $96 \mathrm{kcal} / \mathrm{mol}$, as tetrel atoms tested included the entire $\mathrm{Si}, \mathrm{Ge}, \mathrm{Sn}$ set. Anions of various sorts were among the set of nucleophiles that engaged in tetrel bonds [47], for which the interaction energies were computed at a high level. As is typically the case, the monatomic halides tend to form the strongest such bonds. Although atoms of the first row of the periodic table are reluctant to engage in noncovalent bonds, even the $\mathrm{C}$ of the methyl group participates when coupled with an anion [48]. These tetrel bonding interactions, including those to anions, have recently reviewed by Frontera et al $[49,50]$, particularly with respect to the heavier tetrel atoms $\mathrm{Sn}$ and $\mathrm{Pb}$.

Whereas most calculations involve in vacuo situations, interactions within solvent or biological macromolecules are of great importance. Solvent was found [51] to considerably weaken interaction energies with halides, and to elongate intermolecular distances. Although 
binding strengths of the halides in the gas phase diminish with anionic size, they are much more similar in solution. In a potentially useful finding, calculated free energies of formation of the complexes correlate well with halogen-bonding association constants determined experimentally.

In terms of larger Lewis acids, with multiple atoms that might attract an anion that compete with one another, halides [51] were found able to interact at various sites on a substituted striazine, engaging in both XBs and HBs. The authors noted different behavior between $\mathrm{F}^{-}$and its larger halide cousins. In this same vein, Zhang et al [52] found that an approaching halide can avoid the $\sigma$-hole of the $\mathrm{Cl}$ atom of a molecule like $\mathrm{CHCl}-\mathrm{CHOCH}_{3}$, approaching instead from an angle of some $124-150^{\circ}$ from the $\mathrm{C}=\mathrm{Cl}$ double bond. Another unique geometry is associated with the $-\mathrm{NO}_{2}$ group which attracts a nucleophile like a halide from above the $\mathrm{NO}_{2}$ plane [53] toward what is termed a $\pi$-hole. But an anion such as $\mathrm{NO}_{3}{ }^{-}, \mathrm{Cl}^{-}$or even neutral $\mathrm{CO}$ approaches [54] in such a way as to form more than a single intermolecular contact, as seen in Fig. 5. Anions can be attracted not only to HB or XB groups, but to the $\pi$-systems of aromatic rings as well $[55,56]$, and aerogen bonds to atoms like Xe are another possibility [57, 58].

Whereas inspection of the molecular electrostatic potential (MEP) surrounding a Lewis acid usually provides strong guidance as to just where an anion is likely to attach itself, this is not always the case. When paired with tetracyanopyrazine, complexes with halide anions [59] do not bind where the MEP is most positive. The authors believe these deviations are caused by larger-than-expected donor-acceptor interactions between frontier molecular orbitals. A combined experimental/computational effort [60] noted other weaknesses in the idea of applying a simple electrostatic model to provide correlation with a more comprehensive data set in which both XB donor and acceptor abilities are varied.

Of course, pairing an anion with a cation will result in especially large interaction energies, as when quinuclidine-like cation derivatives interact with any of a set of simple anions [61]. The full range of binding energies of various anions to single ligands are compiled in Tables 2 - 6 . As is the case with HBs, these noncovalent bonds also are at their strongest for the highly concentrated charge within the fluoride anion. There is also of course sensitivity to the specific Lewis acid, and in particular if this ligand carries a charge.

\section{MULTIPLE LIGANDS}

\section{$\underline{1 . \text { Background }}$}

Although the bulk of calculations have been concerned with an anion bound to a single Lewis acid molecule, there are results available that are relevant to the coordination of an anion by multiple binding sites.

The number of ligands was increased to 2 when $\mathrm{Br}^{-}$and $\mathrm{I}^{-}$were each allowed to interact with first one and then two of either $\mathrm{CH}_{3} \mathrm{X}$ or $\mathrm{CF}_{3} \mathrm{X}$ molecules [62]. The total interaction energy increased upon adding the second ligand, but by less than occurred upon a single ligand. The

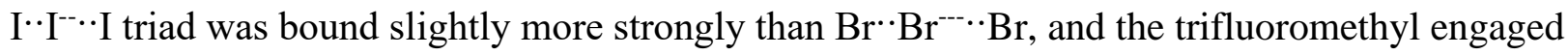
in much stronger halogen bonds than simply $\mathrm{CH}_{3}$. The most strongly bound triad, with an 


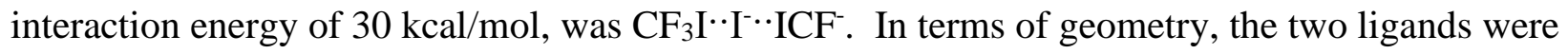
not spaced $180^{\circ}$ apart, but rather manifested $\theta\left(\mathrm{X}^{\cdot} \cdot \mathrm{X} \cdot \mathrm{X}\right)$ angles of only $97^{\circ}$ to $103^{\circ}$.

A crystal structure was the inspiration for an analysis of the interactions between a halide $\left(\mathrm{Cl}^{-}\right.$ and $\mathrm{Br}^{-}$) and a variety of arylbromines [63]. The authors found that the $\mathrm{CBr}^{\cdot} \cdot \mathrm{X}^{-} \mathrm{XBs}$ are of strength comparable to $\mathrm{NH}^{\cdot} \mathrm{X}^{-} \mathrm{H}$-bonds. Another crystal structure shows a possible arrangement of halogen bonding $\mathrm{I}$ atoms around a $\mathrm{SCN}^{-}$anion [64]. Fig. 6 displays an aspect of this geometry, with two XBs to the $\mathrm{N}$ atom and three more to $\mathrm{S}$.

Bryce's group also pursued the idea of a halide centered between a pair of aromatic XB donors [65] as indicated in Fig. 7, focusing on certain spectroscopic aspects, from both experimental solid-state and computational perspectives. The $\theta\left(\mathrm{I} \cdot{ }^{\cdot} \mathrm{X}-{ }^{-} \mathrm{I}\right)$ angle in the crystals under study were again far from linear for the most part, spanning a wide range from $80^{\circ}$ to $176^{\circ}$. The calculations indicated that the lone pair orbitals on the anion govern the magnitude and orientation of the quadrupolar tensor as the geometry about the anion is systematically altered. The authors also observed a correlation between $\eta \mathrm{Q}$ and the $\theta\left(\mathrm{I} \cdot{ }^{\cdot} \mathrm{X}-{ }^{-} \cdot \mathrm{I}\right)$ angle. The XB distance was correlated to both ${ }^{13} \mathrm{C}$ NMR and chemical shifts.

A structural analysis of $\left(\mathrm{Bu}_{4} \mathrm{~N}\right)_{2}\left[\mathrm{Zn}(\mathrm{NCS})_{4}\right] \cdot 3 \mathrm{CBr}_{4}$ crystals [66] uncovered an arrangement whereby each thiocyanate anion is tied to the $\mathrm{Zn}$ as well as to $3 \mathrm{CBr}_{4}$ molecules, as exhibited in Fig. 8a. To clarify certain aspects of the various interactions, DFT calculations were carried out on two and three-point models, shown in Figs 8b and 8c, where the central $\mathrm{Zn}(\mathrm{NCS})_{4}$ unit is attached to respectively two or three $\mathrm{Br}$ atoms of a neighboring $\mathrm{CBr}_{4}$ molecule. They found that the total interaction energy did not increase by adding the third contact. Indeed, even a single $\mathrm{XB}$ contact was just as effective in an energetic sense. This result was attributed to the larger $\mathrm{XB}$ angle deviations required for the greater number of contacts.

The set of halides, including also $\mathrm{NO}_{3}{ }^{-}$and $\mathrm{SO}_{4}{ }^{-2}$, were surrounded by 2-4 pnicogen-bonding

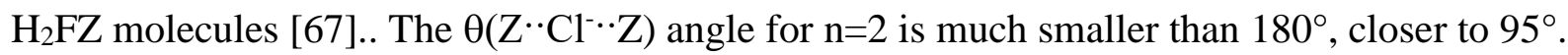
The interaction energies fell in the sequence $\mathrm{SO}_{4}^{-2}>\mathrm{F}^{-}>\mathrm{Cl}^{-}>\mathrm{NO}_{3}>\mathrm{Br}^{-}>\mathrm{I}^{-}$. The geometries for $n=3$ and 4 are roughly trigonal pyramid and tetrahedral, respectively. The structures of the larger complexes for the other anions were not provided with any precision.

\section{Detailed Systematic Calculations}

There have been some recent quantum calculations that address the optimal geometries and energetics of a larger number of ligands clustering around an anion in a systematic manner. This work [27] has focused first on the simple $\mathrm{Cl}^{-}$anion. This halide was surrounded by a set of ligands, of the sort that can engage in $\mathrm{HBs}$ as well as $\mathrm{XB}, \mathrm{YB}, \mathrm{ZB}$ and $\mathrm{TB}$ interactions so as to generate a thorough data set that can foster comparisons of these types of bonds with one another. The number of ligands spanned a range from 2 to 4 so that it is possible to monitor how each new addition to the cluster modifies its geometry and other characteristics.

Beginning with the case of two solvating molecules $(n=2)$, both HBs and YBs are associated with nonlinear geometries [27]. The two $\mathrm{HCl}$ molecules are located about $109^{\circ}$ from one another when surrounding chloride, as illustrated in Fig. 9a. The switch of H-bonding $\mathrm{HCl}$ to Y-bonding 
FSeMe yields a similar structure (Fig. 9b). Fig 9c shows that the change of FSeMe to a linear $\mathrm{Se}=\mathrm{C}=\mathrm{Se}$ ligand increases the angle to $132^{\circ}$. This angle widening is accompanied by longer $\mathrm{R}(\mathrm{Cl} \cdots \mathrm{Se})$ distances due to the weaker basicity of SeCSe as compared to FSeMe.

As $\mathrm{n}$ increases to 3, and a third $\mathrm{HCl}$ ligand is added, the angles remain tetrahedral, and the $\mathrm{H}$ bond lengths are stretched a bit when compared to $n=2$, as may be seen in Fig. 9d. The symmetry is relaxed in the SeCSe YB trimer in Fig. 9e. While two of the $\theta(\mathrm{SeClSe})$ angles are as small as $77^{\circ}$, the third angle widens to $126^{\circ}$. The sum of these three angles is $280^{\circ}$, characteristic of a more pyramidal geometry. That is, the three SeCSe ligands lie closer together than is the case for the three $\mathrm{HCl}$ molecules, where the angle sum is $329^{\circ}$. This distinction may be thought of in terms of the beginnings of clustering between ligands, even for $\mathrm{n}$ as small as 3 .

As the number of ligands increases to 4 , differences between $\mathrm{HB}$ and $\mathrm{XB}$ or YB clustering become more manifest. The four $\mathrm{HCl}$ molecules maintain their tetrahedral separation, as seen in 10a. The total interaction of this tetracoordinated complex is $66.0 \mathrm{kcal} / \mathrm{mol}$. Changes begin to occur from tetrahedral geometry as $\mathrm{HBs}$ are replaced by XBs. Fig $10 \mathrm{~b}$ illustrates that four $\mathrm{BrF}$ molecules provide a roughly tetrahedral ligand grouping, even if two of the $\theta(\mathrm{BrClBr})$ angles are enlarged to $115^{\circ}$. The interaction energy of thetetracoordinated $\mathrm{Cl}^{-}(\mathrm{BrF})_{4}$ complex is 92.6 $\mathrm{kcal} / \mathrm{mol}$, which would be considered as strongly bound. The energy of this system rises very little even if the structure is forced to be purely tetrahedral. Transition to XB ligands ClF leads to a bit more deviation from tetrahedral geometry, as displayed in Fig 10c. The six $\theta(\mathrm{ClClCl})$ angles range from a minimum of $98^{\circ}$ up to $118^{\circ}$. But even with this greater deviation, there is little energy required to force strict tetrahedral angles. More drastic structural changes occur for $\mathrm{ClC} \equiv \mathrm{N}$ ligands, which Fig 10d shows to be a sort of trigonal pyramid. Those angles which include the $\mathrm{ClCN}$ at the apex of this pyramid are all acute. But again, the energy is relatively insensitive to distortion, as a purely tetrahedral geometry lies only $0.4 \mathrm{kcal} / \mathrm{mol}$ higher. Whereas the tetracoordinated HB systems are tetrahedral, clear deviations from this idealized geometry are noted for XB complexes, even if these structures are only slightly more stable than pure tetrahedral.

Greater deviations are associated with YB ligands. Fig. 10e with four $\mathrm{SF}_{2}$ ligands is typical. Perhaps the best characterization of these structures are distorted trigonal pyramids. The three $\mathrm{S}$ atoms in the base of the pyramid are separated from the apical $\mathrm{S}$ atom by less than $100^{\circ}$. The distortion extends to the spacing of the three base $\mathrm{S}$ atoms which are far from evenly spaced. The various $\theta(\mathrm{SClS})$ angles are as small as 55 and as large as $167^{\circ}$. The substitution of $\mathrm{S}$ by its heavier Se congener changes the situation by very little. The three $\theta(\mathrm{SeClSe})$ angles involving the apical Se remain small, in the $72-102^{\circ}$ range, and those involving only the three base Se atoms cover the $73^{\circ}-161^{\circ}$ interval. A further iteration changes one $\mathrm{F}$ atom of $\mathrm{SeF} 2$ to $\mathrm{CH} 3$, which leads to a $81^{\circ}-105^{\circ}$ range for angles including the apex, and a $87^{\circ}-122^{\circ}$ range for base atoms.

Inspection of these figures suggests that the ligands tend to cluster around the chloride in such a way as to leave one hemisphere nearly vacant. This issue was examined by consideration of linear SeCSe ligands since they do not contain substituents that might attract other such 
solvent molecules. But even here, there is some clustering in evidence. Fig $10 \mathrm{f}$ manifests a geometry that could be described as an open umbrella. The molecule that occupies the handle of this umbrella lies some $74^{\circ}$ from those along the three spokes. But there is a great deal of variability within the spokes themselves, with $\theta(\mathrm{SeClSe})$ angles between $75^{\circ}$ and $140^{\circ}$. The total interaction energy is only $47 \mathrm{kcal} / \mathrm{mol}$ for this complex of chloride surrounded by four SeCSe molecules, much less than the $90 \mathrm{kcal} / \mathrm{mol}$ for the $\mathrm{SeF}_{2}$ complexes which also engage in $\mathrm{YBs}$.

The next sort of bonding considered involves the pnicogen family. When four $\mathrm{PF}_{3}$ ligands surround the anion, Fig 11a shows that the open hemisphere above the $\mathrm{Cl}^{-}$remains in place. The larger As atom places the $\mathrm{AsF}_{3}$ molecules into another version of the umbrella, as documented in Fig $11 \mathrm{~b}$. Two of the spoke molecules lie close together, with $\theta(\mathrm{AsClAs})=90^{\circ}$ but the three angles involving the handle are in the $84^{\circ}-89^{\circ}$ range. In contrast, the arrangement of the $\mathrm{PF} 3$ molecules might better be described as a see-saw, with the $\theta(\mathrm{PClP})$ angle between the two opposite $\mathrm{P}$ atoms equal to $169^{\circ}$; all other angles are less than $96^{\circ}$. Fig $11 \mathrm{c}$ shows that the placement of $\mathrm{AsCF}$ molecules leaves the open hemisphere again, aided by very small $\theta(\mathrm{AsClAs})$ handle-spoke angles less than $80^{\circ}$. In terms of interaction energies, the $\mathrm{ZB}$ systems are somewhat less strongly bound than their YB correlates.

A first glance at the open hemisphere might lead to the idea that the ligands tend to cluster together so as to maximize any stabilizing interactions between themselves. This notion was tested in the context of AIM and NBO which both indicated that absence of interligand noncovalent bonds in the $\mathrm{HB}$ and $\mathrm{XB}$ complexes. The $\mathrm{YB}$ and $\mathrm{ZB}$ structures, which differ from $\mathrm{HB}$ and $\mathrm{YB}$ in that there is clustering into a single hemisphere, do exhibit such interligand noncovalent bond. As an example, the complex containing four $\mathrm{SF}_{2}$ molecules manifests a pair of $\mathrm{S} \cdots \mathrm{S}$ YBs, and another between the chloride and a F atom. The total interaction energy involving linear SeCSe molecules is reinforced by four Se $\cdots$ Se YBs. The ZB complexes exhibit similar patterns. In fact, one sees As...As ZBs when linear AsCF ligands are considered, supplemented by a As $\cdots \mathrm{C}$ tetrel bond.

As a central conclusion, whether $\mathrm{HB}$ or $\mathrm{XB}$, four ligands tend toward the vertices of a tetrahedron. On the other hand, when the molecules are capable of interacting with one another, e.g. $\mathrm{HOH}$, which can engage simultaneously in $\mathrm{HBs}$ with each other, this geometrical preference changes. In the case of YB or ZB ligands, the four molecules tend toward a single hemisphere above the central anion, leaving the other hemisphere largely vacant. This arrangement can be traced to intersolvent attractive forces, which are present even in the case of linear solvent molecules like $\mathrm{Se}=\mathrm{C}=\mathrm{Se}$ and $\mathrm{As} \equiv \mathrm{CF}$.

\section{Clustering around Diatomic Anions}

The addition of a second atom to the central anion adds a higher level of complexity. Calculations were carried out for $\mathrm{CN}^{-}, \mathrm{NO}^{-}$, and $\mathrm{OH}^{-}$, surrounded by a set of coordinating molecules again capable of forming $\mathrm{HB}, \mathrm{XB}, \mathrm{YB}$, or TB interactions. The first two anions place an atom adjacent to $\mathrm{N}$ which are similarly on either side of it in the periodic table, so are either 
less or more electronegative than $\mathrm{N}$. $\mathrm{OH}^{-}$offers the possibility of acting as proton donor in a $\mathrm{H}_{-}$ bond, as well as providing an electron donor atom.

$\underline{\mathrm{n}=2}$

The optimized geometries of each of the three anions with a pair of $\mathrm{H}$-bonding ligands $\mathrm{HCl}$ are depicted in the upper panels of Fig. 12. These molecules situate themselves so as to form one $\mathrm{HB}$ with each of the two atoms of $\mathrm{CN}^{-}$. The surprising feature is that the $\mathrm{CN}^{-}$anion has a sufficiently strongly basic nature as to remove the $\mathrm{H}$ from one $\mathrm{HCl}$ molecule, leaving a $\mathrm{ClH}$... NCH.. $\mathrm{Cl}^{-}$configuration. The two $\mathrm{HCl}$ molecules both participate in $\mathrm{HBs}$ with the $\mathrm{N}$ atom of $\mathrm{NO}^{-}$, and in this case both of the protons are extracted from the $\mathrm{HCl}$ molecules, leading to the $\mathrm{Cl}^{-} . . \mathrm{ONH}_{2}{ }^{+} . . \mathrm{Cl}^{-}$system, with two anions surrounding a cation. The structures of $\mathrm{OH}^{-}$are very much like $\mathrm{NO}^{-}$, with both the protons dissociated from the $\mathrm{HCl}$ molecules.

The next panels of Fig. 12 illustrate how each anion engages in a complex with a pair of halogen bonding $\mathrm{FBr}$ molecules. As in the $\mathrm{HB}$ cases, these ligands approach the $\mathrm{CN}^{-}$from either end, and both attack the $\mathrm{N}$ atom of $\mathrm{NO}^{-}$and the $\mathrm{O}$ of $\mathrm{OH}^{-}$. The $\mathrm{Br}$ atom lies nearly midway between the $\mathrm{C}$ and the $\mathrm{F}$, so might be better characterized as Br-shared. Similar sharing occurs in most of the other complexes as well. In all cases, the XB complexes are more strongly bound than are their H-bonding parallels.

The most stable geometries of each anion with the $\mathrm{YB} \mathrm{SeF} 2$ are illustrated in the next panels of Fig. 12. The general geometric patterns remain in terms of positioning of the two ligands: one on either end of $\mathrm{CN}^{-}$, and both located so as to interact with the $\mathrm{N}$ of $\mathrm{NO}^{-}$and the $\mathrm{O}_{\text {of }} \mathrm{OH}^{-}$. On the other hand, there are certain large-scale deformations of some of the monomers. When bound to $\mathrm{OH}^{-}$, for example, one of the $\mathrm{SeF}_{2}$ molecules distorts from a bent to a very nearly linear structure. This distortion comes with a cost. The particular distortion of this $\mathrm{SF}_{2}$ molecule from its optimized structure to that adopted in this configuration requires $68.5 \mathrm{kcal} / \mathrm{mol}$, so there is clearly some important benefit afforded by this deformation in terms of the interaction. The binding energies of these chalcogen-bonded configurations are smaller than their $\mathrm{XB}$ counterparts but follow the same $\mathrm{CN}^{-}<\mathrm{OH}^{-}<\mathrm{NO}^{-}$pattern.

The binding energies suffer another drop when chalcogen atoms are replaced by pnicogens, while changing the order to $\mathrm{CN}^{-}<\mathrm{NO}^{-}<\mathrm{OH}^{-}$. The geometric dispositions in Fig. 12 remain largely unchanged from the other types of ligands and these $\mathrm{ZF}_{3}$ ligands do not manifest any inter-ligand interactions. These same geometrical arrangements persist for TB ligands in the next panels of Fig. 12, but with some new wrinkles. Structures appear in which there are one or more $\mathrm{F}$ atoms shared between the two ligands, representing an extreme form of inter-ligand interaction. In the structure pairing $\mathrm{OH}^{-}$with $\mathrm{GeF}_{4}$, the $\mathrm{OH}^{-}$anion serves as a proton donor in a $\mathrm{H}$-bond with an $\mathrm{F}$ atom of one of the $\mathrm{GeF}_{4}$ ligands. The binding energies of these $\mathrm{TB}$ complexes deviate from the drops seen on progressing from halogen to chalcogen to pnicogen; the tetrel values grow to rough equivalence with the XB systems. One also observes a sharp increase in $\mathrm{OH}^{-}$binding energies to the point where it is the most strongly bound of all three anions. Indeed, the tetrel bonded $\mathrm{OH}^{-}$complexes exceed even the $\mathrm{H}$-bonded systems. One factor in the latter 
strength is the formation of T-F $\cdots$ T tetrel bonds between ligands, a phenomenon which does not occur of the other sorts of ligands.

Triel-bonded $(\mathrm{TrB})$ complexes characterized by $\mathrm{GaF}_{3}$ are even stronger. Part of their magnitude can be attributed to the electron-deficient nature of the Tr atoms As was the case for $\mathrm{H}$ and T-bonding, $\mathrm{OH}^{-}$and $\mathrm{CN}^{-}$represent the most strongly and weakly bound anions, respectively. These triel ligands generally maintain the basic disposition of the other ligands. These $\mathrm{TrF}_{3}$ units are far enough apart that there are no interactions between ligands.

$\underline{\mathrm{n}=3}$

As may be seen in the top panels of Fig. 13, one of the three $\mathrm{HCl}$ molecules again transfers its proton to the $\mathrm{CN}^{-} \mathrm{C}$ atom, and the other two $\mathrm{HCl}$ molecules congregate around the $\mathrm{N}$. And while both $\mathrm{HCl}$ molecules lost their proton to the $\mathrm{N}$ atom of $\mathrm{NO}^{-}$for $\mathrm{n}=2$, there is only one such full transfer when a third $\mathrm{HCl}$ is added, the other proton being roughly equally shared between the $\mathrm{N}$ and $\mathrm{Cl}$ atoms. Note also that the third $\mathrm{HCl}$ engages with another $\mathrm{HCl}$ rather than the central anion. With respect to $\mathrm{OH}^{-}$, one $\mathrm{HCl}$ molecule donates its proton to the $\mathrm{O}$ atom. The addition of the third ligand adds an increment to each binding energy, relative to $n=2$, but this increment varies with anion and $\mathrm{HX}$. As in the dicoordinated systems, $\mathrm{OH}^{-}$is most tightly bound and $\mathrm{CN}^{-}$the least. $\mathrm{HCl}$ is more tightly bound than $\mathrm{HF}$ to $\mathrm{NO}^{-}$, but there is little distinction between them for $\mathrm{CN}^{-}$and $\mathrm{OH}^{-}$.

As observed for $n=2$, there are again elements of halogen transfer for $n=3$. The overall geometries in Fig. 13, though, can be considered as a fairly simple addition of the third ligand. This ligand adds to the $\mathrm{N}$ atom of $\mathrm{CN}^{-}$and to the $\mathrm{O}$ atoms of $\mathrm{NO}^{-}$and $\mathrm{OH}^{-}$. The third chalcogenbonding ligand adds in much the same way as was noted for the $\mathrm{XB}$ units. When there are three $\mathrm{YF}_{2}$ molecules present, the deformation of one of them to a quasi-linear shape becomes standard for all three anions, whereas it only occurred for $\mathrm{OH}^{-}$when $\mathrm{n}=2$. With the addition of a third $\mathrm{YF}_{2}$ molecule, a new element creeps into the factors contributing to the geometries. For example, the upper left Se atom in Fig. 13 lies $3.079 \AA$ from the $\mathrm{N}_{\text {of }} \mathrm{CN}^{-}$, but also approaches to within 3.73 $\AA$ of another $\mathrm{SeF}_{2}$, engaging in a $\mathrm{Se} \cdot \mathrm{F}$ chalcogen bond. In fact, one or more of these inter-ligand interactions are present for all of the structures with three $\mathrm{YF}_{2}$ molecules, including $\mathrm{NO}^{-}$and $\mathrm{OH}^{-}$ . It is probably because of the addition of this new inter-ligand stabilizing interaction, that most of the binding energies for $\mathrm{YF}_{2}$ are larger than their XF parallels. The same sort of inter-ligand interactions appears in the $\mathrm{ZB}$ systems as well. As was noted above for $n=2$, the pnicogen ligands bind more weakly to each of the anions than do the chalcogens for $n=3$ as well.

The transition from $\mathrm{ZB}$ to $\mathrm{TB}$ had dramatically raised the binding energies for $\mathrm{n}=2$, and that same pattern occurs for $n=3$. While the crowded nature of the $T$ atoms precludes their approach by any but the central anion, there are numerous inter-ligand interactions involving $\mathrm{F}$ atoms, even to the point of sharing $\mathrm{F}$ atoms between a pair of tetrel atoms. Despite its formal negative charge $\mathrm{OH}^{-}$is able to act as proton donor in a $\mathrm{OH} . . \mathrm{F}$ HB. The binding energies of $\mathrm{NO}^{-}$and $\mathrm{OH}^{-}$ rise considerably upon adding a third ligand, due in part to these augmenting effects. The addition of the third ligand increases the binding energy of $\mathrm{CN}^{-}$by a smaller amount since it adds 
only a weak interaction with the $\pi$-system of the anion, and several weak inter-ligand $\mathrm{F} \cdot \mathrm{F}$ interaction.

Quite large increments of 47-57 kcal/mol occur in the TrB systems upon adding a third ligand. These large increases are due in part to a host of inter-ligand bonds involving their $\mathrm{F}$ atoms, that were absent until the third molecule was added. AIM analysis suggests that these ligand-ligand interactions are of comparable strength to those involving the central anion. The binding energies now approach and exceed $200 \mathrm{kcal} / \mathrm{mol}$, largest for $\mathrm{OH}^{-}$.

$\underline{\mathrm{n}=4}$

$\mathrm{HCl}$ adds to the prior $\mathrm{CN}^{-}$complex with three $\mathrm{HCl}$ molecules by simply adding another $\mathrm{HB}$ to the $\mathrm{N}$, as depicted in Fig. 14. The fourth $\mathrm{HCl}$ molecule results in double proton transfers to both $\mathrm{NO}^{-}$and $\mathrm{OH}^{-}$, leading to a central $\mathrm{H}_{2} \mathrm{NO}^{+}$and $\mathrm{H}_{3} \mathrm{O}^{+}$, respectively, along with a pair of $\mathrm{Cl}^{-}$ anions. The latter are stabilized by formation of two $\mathrm{HBs}$ each. The fourth FBr interacts via a combination of a $\mathrm{OH} \cdot{ }^{*} \mathrm{Br} \mathrm{HB}$ and a $\mathrm{Br} \cdot \cdot \mathrm{Br} \mathrm{XB}$ to another $\mathrm{BrF}$. These last ligands add an increment in the range of $6-10 \mathrm{kcal} / \mathrm{mol}$ to the $\mathrm{n}=3$ binding energies, but a larger increment of 13 $\mathrm{kcal} / \mathrm{mol}$ for the fourth $\mathrm{FBr}$ which engages in the aforementioned pair of noncovalent bonds.

Rather than fitting itself in to interact with $\mathrm{CN}^{-}$directly, the fourth $\mathrm{SeF}_{2}$ molecule instead presents each system with a ring configuration, with several $\mathrm{Se} \cdot$ Se chalcogen bonds augmenting the two direct interactions with the central anion, as well as several Se $\cdot$ F chalcogen bonds. The pnicogen atoms also form an interconnected ring around the central anion, but one in which the anion occupies more of a central location, and in which the ligands are connected to one another via $\mathrm{As}{ }^{*} \mathrm{~F}$ pnicogen bonds. Both the $\mathrm{C}$ and $\mathrm{N}$ atoms of $\mathrm{CN}^{-}$engage in $\mathrm{ZBs}$, and the $\mathrm{N}$ of $\mathrm{NO}^{-}$ forms two $\mathrm{ZBs}$. In addition to the $\mathrm{OH} \cdot \mathrm{Z} \mathrm{HB}$ of $\mathrm{OH}^{-}$with one ligand, the $\mathrm{O}$ engages in three pnicogen bonds.

The central $\mathrm{CN}^{-}$anion engages in two tetrel bonds with $\mathrm{GeF}_{4}$. The third and fourth $\mathrm{GeF}_{4}$ associate via noncovalent bonds to the first two ligands; a similar arrangement occurs with $\mathrm{NO}^{-}$. The $\mathrm{H}$ of $\mathrm{OH}^{-}$forms a $\mathrm{OH} . . \mathrm{F} \mathrm{HB}$ with the fourth ligand, as the $\mathrm{O}$ atom is engaged in a pair of tetrel bonds. One sees a higher degree of F-sharing between Ge atoms. The F-sharing becomes even more predominant in the $\mathrm{GaF}_{3}$ ligands, whose arrangements are surprisingly similar to the ZB ligands, except that the ligand-ligand associations become more prominent here in that there are two ligands with little connection to the central anion.

In terms of binding energies, the $\mathrm{HB}, \mathrm{ZB}, \mathrm{TB}$, and $\mathrm{TrB}$ ligands follow the $\mathrm{OH}^{-}>\mathrm{NO}^{-}>\mathrm{CN}^{-}$ pattern, whereas the $\mathrm{NO}^{-}$exceeds $\mathrm{OH}^{-}$for $\mathrm{XB}$ and $\mathrm{YB}$. The strongest interactions occur for the TrB ligands with binding energies reaching $300 \mathrm{kcal} / \mathrm{mol}$ for $\mathrm{n}=4$. Tetrel and chalcogen bonds are next in magnitude; the remaining types of ligands do not fit a simple and consistent pattern.

\section{MULTIPLY COORDINATED ANION RECEPTORS}

A particularly fascinating offshoot concerning the coordination of anions lies in the efforts over recent years to design and construct receptors for anions. The central goal is to make these receptors strong, so that they might pull the anions out of a solution in which they might exist in 
low concentration. Another objective is selectivity, in that an optimal receptor can bind one anion much more strongly than others, even those closely related to it. Whereas biological evolution has developed some very specific and selective anion binding agents, modern technology lags behind. Many receptors make use of general electrostatic interactions, and sometimes of H-bonds [68-74]. The thiourea molecule, for example, is a widely used [75-79] anion binder, taking advantage of its $\mathrm{H}$-bonding capability. The guanidinium cation and its derivatives $[80,81]$ have also found use in this regard.

However, the anion receptors that have been developed to date still suffer from certain disadvantages. Their selectivity lags behind what is needed, or they are unable to detect the presence of a particular anion below a given concentration threshold. In fact, at this point in time, the biggest need is the development of highly selective receptors that can function in an aqueous, rather than organic or biological environment. As mentioned in a recent review [82], "examples of receptors that are neutral or of low charge and operate in organic-aqueous mixtures are uncommon, and those that function in $100 \%$ water are rarer still”.

The central idea guiding the search for such receptors relies on the formation of several binding interactions to the anion simultaneously, so as to amplify the strength of each one in the final complex. Some early modest success had been achieved by relying on HB interactions, in that the receptor contained several HB proton donor groups. But along with the emergence of $\mathrm{XB}$ and related noncovalent bonding, came the notion that perhaps one might use these interactions to replace the HBs. Systems were thus designed that contained bipodal and even tripodal and higher order receptors, containing $\mathrm{C}-\mathrm{X}$ or $\mathrm{N}-\mathrm{X}$ bonds, each of which could interact strongly with a given anion.

\section{Experimental Developments}

An early effort by the Taylor group [83] constructed a tripodal receptor, such that I atoms on aromatic groups formed XBs with an anion. The computed geometry of this receptor is shown in Fig. 15a, binding a chloride anion. While its binding strength was only modest when compared to synthetic receptors at the time, it was nonetheless the highest-affinity receptor of this type developed to that point by several orders of magnitude. This idea was expanded upon in the same year [84] to consider tridentate receptors involving more than just I-XBs and even $\mathrm{CH} \cdots \mathrm{X}^{-}$ HBs. A combination of both XBs and HBs proved effective as well [85]. In some preliminary calculations involving halides and iodobenzene, Sarwar et al [86] found the binding of anions decreased in the order $\mathrm{Cl}^{-}>\mathrm{Br}^{-}>\mathrm{I}^{-}$. They then placed two substituted perfluorosubstituted phenyl groups on a single molecule and measured its binding to halides. They found the longer four-carbon spacer better accommodated the $\mathrm{Cl}^{-}$anion, and that enlarging the system to a tridentate receptor further improved the binding.

Beer's group considered a bidentate bromoimidazoliophane receptor [87] to capture $\mathrm{Br}$ anions in aqueous solution via halogen bonding. Another effort [88] attempted to improve upon the interaction by activating the $\mathrm{C}-\mathrm{X}$ bond via strong XBs. This same group has used a picketfence scaffold on which to place iodinated triazole rings that can engage with an anion [89] as well as a rotaxane framework $[90,91]$. Introduction of metal atoms into the receptor (Fig. 15b) 
led to strong anion recognition [92], a result that was mirrored soon thereafter [93] with $\mathrm{Ru}(\mathrm{II})$ metal atoms amidst halogen bonding iodotriazole units and $\alpha$-cyclodextrin structured anion receptors to capture perrhenate [94] as illustrated in Fig. 15c.

The Beer group upped the ante in 2016 [95] by synthesizing an anion receptor with four stations within a rotaxane framework. A later work considered neutral iodotriazole foldamers which could serve as tetradentate halogen bonding anion receptors [96]. Two views of the complex with $\mathrm{I}^{-}$are displayed in Fig. 15d. Another tetradentate receptor was tested [97] two years later which utilized an interlocked host framework, as exhibited in Fig. 16a. This class of receptors, part of a foldamer molecular film, selectively binds perrhenate, iodide and thiocyanate anions in water.

Without needing charge on the receptor to attract an anion, neutral XB rotaxanes containing 2,3 , and 4 iodotriazole groups integrated into the rotaxane macrocycle were found to be excellent anion binding agents [98]. The authors were able to adjust the strength and selectivity of binding by modifying the number and position of XB iodotriazole groups. The best halide receptors were those with the largest number of XB groups. Another sort of tetrapodal receptor [99] utilizes four 2-I-imidazolium binders, all attached to a central phenyl ring, to bind halides in both organic and aqueous media

Halogen bonding receptors have also been applied [100] to the discrimination of stereoisomers of a dicarboxylate anion. A pair of halogen-bearing triazolium entities surrounded a pyrrole spacer [101] in a receptor applied to oxoanion binding, as in Fig. 16b.

Another active group in this arena is that of Huber who used isothermal calorimetric titration to determine the strong effect of entropy [102] in the binding of halides to bidentate XB receptors. A pair of I-substituted imidazolium units engaged a halide in a bipodal fashion [103], as illustrated in Fig. 16c, for which some catalytic activity was observed. This group later verified [104] via isothermal titration calorimetry, NMR, and calculations that halogen bonding does in fact occur when 2-haloimidazolium salts are mixed with anions. They also constructed $\mathrm{XB}$ receptors [105] where the I atom was incorporated directly into a central ring, as depicted in Fig. 16d.

There have also been efforts to carry out the sensing and recognition of anions using XBs embedded within catenane skeletal structures [106], and modified imidazoliums within other macromolecular geometries [107], as in Fig. 17a. An interesting study [108] compared binding of larger anions like $\mathrm{PF}_{6}{ }^{-}, \mathrm{H}_{2} \mathrm{PO}_{4}^{-}$, and $\mathrm{SO}_{4}{ }^{-2}$ by a set of bipodal $\mathrm{XB}$ receptors by use of NMR.

The influence of the specific halogen atom, the electron-withdrawing group, and the group linking together the two legs of the receptor were assessed [109] by NMR and isothermal titration calorimetry and the results suggested smaller halides are preferred over larger ones but that sulfate is bound more strongly than halides. An example of the sulfate bound to one of these receptors is illustrated in Fig. 17b.

The superiority of XB over $\mathrm{HB}$ anion receptors was shown again [110] in terms of stronger, water resistant halide binding. The number of XB groups participating in the binding of a halide can be raised by changing the structure. The Berryman group [111] showed an iodide anion can 
be encapsulated by a triple helicate via several XBs. The receptors were expanded into supramolecular polymer type structures [112] which bind anions of several charges, $\mathrm{SO}_{4}{ }^{-2}$, $\mathrm{H}_{2} \mathrm{PO}_{4}{ }^{-}$and $\mathrm{HP}_{2} \mathrm{O}_{7}^{-3}$, by a combination of XBs and HBs. Another study examined the effect of the charge on the receptor [113] and found XB molecules based on either a bis(iodotriazolium)benzene or a bis(iodotriazolyl)-pyridinium showed little effect of this charge, whether +1 or +2 .

A variation on this theme was developed [114] by Riel et al in which the two binding groups of the bidentate receptor were separated by a fairly long spacer group containing both a phenyl ring and two $\mathrm{C} \equiv \mathrm{C}$ spacers on either side. A similar pattern of this same large spacer group was found an effective anion binder [115]. In this case the central species was a pyridinium, flanked by a pair of iodobenzene groups.

Another interesting structural motif is that of a cyclopeptide, containing halogen-substituted triazole units, as pictured in Fig. 17c where it is binding a chloride anion [116]. In addition to the three XBs, there are also three HBs involved in the cage structure.

The conversation expanded a bit in 2015 [117] when the Taylor group went beyond XBs, successfully incorporating chalcogen bonding into the receptor. The $\mathrm{Y}$ atom was situated on a 5-membered ring, bonded on both sides by $\mathrm{N}$ atoms. This same idea was expanded upon [118] a year later in the form of a bipodal Te-related YB receptor, visualized in Fig. 17d. The idea of replacing XBs by YBs in anion recognition received a boost in 2016 [119] when S-containing dithieno-thiophene molecules of the type illustrated in Fig. 18a were shown to bind halides. This YB concept was further refined soon thereafter [120] in a receptor where anions were bound to rotaxanes via YBs, as illustrated in Fig. 18b. A year later, another group bound a series of anions including $\mathrm{CN}^{-}$and $\mathrm{YCN}^{-}$(Y=one of several chalcogen atoms) by 1,2,5-chalcogenadiazoles [39], and the Beer group [121] measured the thermodynamics of anions bound to other chalcogenbinding receptors, and one that incorporated Te in particular. In another study, this same group [122] compared binding of both chiral XB and YB receptors and found different anion selectivities for dicarboxylate isomers. A very recent work [123] has supported the idea of using YB receptors, especially in aqueous phase. Calorimetric measurements showed these receptors to display strong and selective binding for large weakly hydrated anions such as $\mathrm{I}^{-}$and $\mathrm{ReO}_{4}{ }^{-}$.

In addition to anion-binding receptors based on XBs and YBs, there is also evidence that tetrel bonds can be added to this arsenal. The idea that a Sn atom in particular could participate in anion binding via tetrel bonds was advanced by the Jurkschat group [124]. They linked a $\mathrm{Ph}_{2} \mathrm{FSnCH}_{2} \mathrm{SnFPh}-\mathrm{CH}_{2}$ moiety to $19-$ crown- 6 and found rapid transport of $\mathrm{KF}$. The structure in Fig. 18c holds the $\mathrm{F}^{-}$via a pair of $\mathrm{Sn}^{\cdots} \mathrm{F}$ tetrel bonds, and the $\mathrm{K}^{+}$is bound in the crown segment. This group has recently reviewed developments in using organotin complexes as anion receptors [125]. The variety of shapes in which these receptors come, and the versatility of the coordination around the anions is exhibited in a number of these structures in Fig. 19.

In addition to the $\mathrm{XB}, \mathrm{YB}$, and $\mathrm{TB}$ receptors, a very recent work has extended this theme to pnicogen bonds as well [126]. Lee et al find that both $\mathrm{Te}$ and $\mathrm{Sb}$, as YB and $\mathrm{ZB}$ agents, 
respectively, are three orders of magnitude more effective transmembrane anion transporters as the XB I atom.

The forgoing represents just an outline of some of the work that has been carried out in the last decade concerning the development of multipodal anion receptors based on these noncovalent bonds. Much more detail and a fuller development can be gleaned from several recent reviews [127-131].

\section{Computational Exploration}

The experimental data presents a problem bursting at the seams with possibilities. While the bulk of the prior work had concentrated on halogen bonds in a wide variety of frameworks, geometries, bonding situations, charges, and so forth, workers are shifting the focus of their attention to chalcogen, pnicogen, and tetrel bonds which may offer additional dials by which to tune the binding and selectivity in unprecedented ways. In an attempt to provide guidance in these efforts, and to develop a set of principles of rational synthesis of new receptors, a number of quantum chemical studies have been carried out.

Some examples of how quantum calculations have been able to contribute to this conversation may illustrate this point. Bis-triazole-pyridine (BTP) has been shown to be an effective halide chelator, through two or perhaps three $\mathrm{H}$-bonds. The two $\mathrm{H}$ atoms on each of the two triazole rings can be replaced by halogen atoms, as indicated by the $\mathrm{X}$ atoms in Fig. 20, which would replace two of the $\mathrm{CH}^{\cdot} \mathrm{Y}^{-} \mathrm{HBs}$ by a pair of $\mathrm{CX} \cdot \mathrm{Y}^{-} \mathrm{XBs}$, where $\mathrm{Y}$ represents the halide that is being chelated [132]. There are several perturbations one can make to this model system. In the first place, the coordinating halide can be any of $\mathrm{F}^{-}, \mathrm{Cl}^{-}, \mathrm{Br}^{-}$, or $\mathrm{I}^{-}$. Secondly the $\mathrm{X}$ atoms on the receptor can represent any of the halogen bonding atoms $\mathrm{Cl}, \mathrm{Br}$, or I. And the total charge on the receptor can be any of $0,+1$ or +2 , by adding $-\mathrm{CH}_{3}{ }^{+}$groups to the locations indicated in Fig. 20. The calculations described below were carried out in a polarizable continuum of water so as to mimic aqueous solution conditions

The coordination of the halide by this receptor is illustrated in Fig. 21; in these examples, the total charge is +1 , the halide is $\mathrm{F}^{-}$, and the $\mathrm{X}$ atoms that coordinate with it are both $\mathrm{H}$ and $\mathrm{I}$. Note that the halide fits nicely into the coordination provided by the receptor. The binding energies of the entire set of systems are displayed in Table 7 where several trends are immediately clear. The $\mathrm{F}^{-}$binds most strongly, followed in diminishing order by larger halides: $\mathrm{F}^{-}>\mathrm{Cl}^{-}>\mathrm{Br}^{-}>\mathrm{I}^{-}$. Replacement of the two $\mathrm{H}$ atoms of the receptor by $\mathrm{Cl}$ weaken the interaction, while $\mathrm{Br}$ and $\mathrm{I}$ strengthen it in that order, i.e. the $\mathrm{Br}$ and I XBs are superior to HBs. And finally, the interaction is strengthened as the positive charge of the receptor rises, not surprising in view of the simple Coulombic law.

In terms of how the energetics translate into binding, Table 8 indicates the ability of each of the halogen bonding atoms to outdo $\mathrm{H}$. In other words, the equilibrium ratio of binding of the indicated halide by $\mathrm{X}$ vs $\mathrm{H}$ shows the obvious superiority of $\mathrm{I}$ over $\mathrm{H}$, with ratios varying between 660 and $2 \times 10^{7}$. $\mathrm{Br}$ is only slightly superior to $\mathrm{H}$, whereas $\mathrm{Cl}$ is inferior, with ratios typically well below unity. Another way to look at this issue is via selectivity for one halide over 
another. As mentioned above $\mathrm{F}^{-}$binds most strongly of all the other halides. When placed into the perspective of the equilibrium ration of this anion over the other halides, the selectivity for $\mathrm{F}^{-}$ is quite high. As illustrated in Table 9, this selectivity is somewhat akin to the preferences expressed in Table 8. That is $\mathrm{X}=\mathrm{Cl}$ is only mildly selective, $\mathrm{H}$ more so, $\mathrm{Br}$ better, but $\mathrm{I}$ is best of all. Its equilibrium ratio of $\mathrm{F}^{-}$over the other halides is at least 1,000 and as large as $2 \times 10^{6}$. So the replacement of HBs on the receptor by XBs, particularly X=I not only binds halides much more strongly, but also adds to the selectivity of one halide over another.

As another perturbation, one can consider substituents placed upon these same triazole rings. As shown in Fig. 22, the $\mathrm{Z}$ substituents were placed [133] adjacent to the $\mathrm{X}$ atoms that coordinate directly with the halides. As can be seen in Fig. 23, the binding energy rises as the $\mathrm{Z}$ substituent become more electron withdrawing, from $\mathrm{NH}_{2}$ to $\mathrm{NO}_{2}$ on either extreme. This pattern persists whether the halide is $\mathrm{F}^{-}$(green), $\mathrm{Cl}^{-}$(olive), $\mathrm{Br}^{-}$(red), or I- (purple), and whether the coordinating atoms are $\mathrm{H}$ (broken curves) or I(solid). Note also that the superior binding of Ibonds over HBs persists. But the calculations to suggest that one can add to the ability of I XBs to bind strongly and selectively by adding electron-withdrawing substituents to the triazole rings. While Fig. 22(I) refers to the neutral receptor, the patterns in the dicationic receptor [Fig. 22(II)] are very much the same.

Still another variation can be considered in terms of the spacer in the receptor. That is, the phenyl ring in Fig. 22 can be replaced by any of a number of other sorts of groups, each of which would induce certain geometric and inductive perturbations on the coordination of the halide. Along with the original phenyl ring shown in Fig. 24a, other spacers tested [134] include the thiophene in Fig. 24b, a carbazole as in Fig. 24c, and dimethylnaphthalene illustrated in Fig. 24d. In the same vein, the triazole groups considered earlier can be substituted by imidazole groups, which are reflected in the structures of Fig. 24. While those pictured place I atoms on the imidazolium groups, $\mathrm{H}$ and $\mathrm{Br}$ were also placed into the mix. And as before, the entire panoply of halides $\mathrm{F}^{-}, \mathrm{Cl}^{-}, \mathrm{Br}^{-}$, and $\mathrm{I}^{-}$were taken as coordinated bound anions. Regardless of the spacer chosen, the order of binding remained $\mathrm{F}^{-}>\mathrm{Cl}^{-}>\mathrm{Br}^{-}>\mathrm{I}^{-}$, and the $\mathrm{I}$ atom was much more effective in binding the halide, with an enhancement of binding as large as 13 orders of magnitude. Imidazolium was found to be more effective than triazolium. Benzene and dimethylnaphthalene represent the best spacers, followed by thiophene and carbazole.

The coordination around the halides does not have to be limited to halogen bonds. As an extension of this idea, YBs, ZBs, and TBs were added to the mix [135]. The receptors take as their starting point a dithieno thiophene framework in which two $\mathrm{S}$ atoms can engage in a pair of YBs with a nucleophile, as pictured in Fig. 25a. To that is added zero, one, or two $\mathrm{O}$ atoms the thiophene $\mathrm{S}$ which is not directly involved in the interaction with the halides, as displayed in Figs $25 \mathrm{~b}$ and $25 \mathrm{c}$, respectively. Although perhaps remote, it was thought that such additions might affect the coordination of a halide. The two $S$ atoms which engage in chalcogen bonds with the halide, are replaced by $\mathrm{P}$ and As atoms to compare chalcogen with pnicogen bonding, as indicated in Figs 26b and 26c, respectively. The replacement by Ge, shown in Fig. 26d permits study of TBs with the receptor. As in the earlier cases, $\mathrm{F}^{-}$is bound most strongly, followed by 
$\mathrm{Cl}^{-}>\mathrm{Br}^{-}>\mathrm{I}$. Replacing $\mathrm{S}$ by the ZBs of $\mathrm{P}$ enhances the binding, as does changing to the larger As. Another increment accompanies the switch to the TBs arising from Ge. Despite the distance of the thiophene $\mathrm{S}$ atom from the binding site, the binding energy enlarges along with each additional $\mathrm{O}$ atom added to it. The final binding energy can be quite large, as much as 63 $\mathrm{kcal} / \mathrm{mol}$ for the $\mathrm{Ge}^{\cdot} \mathrm{F}^{-}$interaction. One sees again a strong selectivity for fluoride over the other halides, which can be as large as 27 orders of magnitude. The data suggest that the switch from halogen to the other noncovalent bonds, particularly tetrel, offer unique opportunities for binding strength and selectivity. There were related calculations several years later [136] that verified these ideas, and found interaction energies are much reduced in a simulated solution environment.

Given the newfound effectiveness of tetrel bonds to bind halides, some further ideas were tested [137] regarding how to construct an optimal receptor. Beginning with a monopodal imidazolium, its $\mathrm{CH}$ was replaced first by I and then by tetrel groups $\mathrm{SnH}_{3}$ and $\mathrm{SiF}_{3}$. The three $\mathrm{F}$ atoms on the latter group made it the strongest halide binder. The simple addition of a phenyl ring had little effect. On the other hand, placing two such modified imidazolium rings in a bipodal arrangement enhanced the binding, but did not double it. On one hand, replacement of the $\mathrm{H}$ atom on the imidazolium groups with the halogen-bonding I has an inconsistent effect, the binding with either halide is significantly enhanced by tetrel-bonding $\mathrm{SnH}_{3}$, and $\mathrm{SiF}_{3}$ even more so. The tetrel-bonding receptors are the most selective for $\mathrm{F}$ - over $\mathrm{Cl}$ - with an equilibrium ratio on the order of $10^{14}$ for $\mathrm{SnH}_{3}$ and $10^{28}$ for $\mathrm{SiF}_{3}$. When combined with their strong halide binding, $\mathrm{SiF}_{3}-\mathrm{ImF}_{3}-\mathrm{Bz}-\mathrm{ImF}_{3}-\mathrm{SiF}_{3}{ }^{+2}$ bipodal receptors represent an optimal choice in terms of both binding strength and selectivity.

Taking this information as a starting point several more dicationic receptors were constructed [138] based on a pair of imidazolium units, connected via a benzene spacer. The $\mathrm{CH}$ groups on each imidazolium was replaced by $\mathrm{Br}, \mathrm{Se}, \mathrm{As}$, and $\mathrm{Ge}$ so as to model $\mathrm{XBs}$, YBs, ZBs and TBs, respectively. The coordination of chloride by each of these prototype receptors is illustrated in Fig. 27. Regardless of the binding group considered, $\mathrm{F}^{-}$is bound much more strongly than are $\mathrm{Cl}^{-}$and $\mathrm{Br}^{-}$, but the binding energy is not very sensitive to the nature of the binding atom for $\mathrm{Cl}^{-}$ and $\mathrm{Br}^{-}$, even if $\mathrm{H}$. On the other hand, one notes a great deal of differentiation with respect to $\mathrm{F}^{-}$, where the order varies as $\mathrm{TB}>\mathrm{H} \sim \mathrm{ZB}>\mathrm{XB}>\mathrm{YB}$. The replacement of each of these binding atoms by their analogues in the next row of the periodic table raises the fluoride binding energy by $22-56 \%$. The strongest $\mathrm{F}^{-}$binding agents take advantage of the TBs of Sn, whereas it is Ihalogen bonds that are preferred for the two larger halides. After incorporation of thermal and entropic effects, the $\mathrm{XB}, \mathrm{YB}$, and $\mathrm{ZB}$ receptors do not represent much of an improvement over $\mathrm{HBs}$ with regard to this selectivity for $\mathrm{F}^{-}$, even I which binds quite strongly. In stark contrast, the Ge and $\mathrm{Sn}$ TB derivatives manifest by far the greatest selectivity for $\mathrm{F}^{-}$over $\mathrm{Cl}^{-}$and $\mathrm{Br}^{-}$, as much as $10^{13}$, an enhancement of six orders of magnitude when compared to the H-bonding receptor.

Ortolan et al [139] considered the electron-deficient cavity of heterocalixarenes and a full range of anions: $\mathrm{Cl}^{-}, \mathrm{Br}^{-}, \mathrm{I}^{-}, \mathrm{BF}_{4}^{-}, \mathrm{CH}_{3} \mathrm{CO}_{2}{ }^{-}, \mathrm{H}_{2} \mathrm{PO}_{4}^{-}, \mathrm{HSO}_{4}^{-}, \mathrm{NCS}^{-}, \mathrm{NO}_{3}^{-}, \mathrm{PF}_{6}^{-}$, and $\mathrm{SO}_{4}^{-2}$. They found the anions bound to multiple sites, and the particular form of bonding ranged among 
anion- $\pi$, lone pair- $\pi$, HB, as well as $\sigma$-hole. Some of these bound complexes are displayed in Fig. 28.

\section{PROSPECTS}

Past work has opened new vistas in terms of halogen, chalcogen, pnicogen, and tetrel bonds which have placed them firmly in the chemist's arsenal of important intermolecular interactions. It is now clear that they are competitive in strength with their better known H-bond cousin, and new applications of these noncovalent bonds appear in the literature on what seems like a daily basis. Although these interactions with anions are presently less thoroughly studied than their neutral analogues, that situation is changing quickly. It seems certain that new results and insights will lead to a rapidly developing understanding of the clusters that are formed by these ligands around anions of all sorts. It ought to be fairly soon when rules will be established as to the structure that can be expected when a given number of ligands surrounds monoatomic and larger anions. Principles will be forthcoming as to the competition between one sort of ligand and another, with ligands of any given charge and atomic configuration. In summary, in short order we will have as solid an understanding of the coordination of an anion by these $\sigma$-hole ligands as is currently the case for H-bonded systems.

The work reviewed here has concentrated on the geometry of the clusters, and the strength of binding, as well as its fundamental nature in terms of basic principles of noncovalent bonding. But there are a plethora of areas where the conclusions will have practical applications. One of these areas, which was explored in some depth above involves poly-coordinating anion receptors. It is hoped that the ideas discussed here will guide experimentalists in the construction of new and more effective receptors. Just as some H-bonding receptors have demonstrated selectivity for certain sizes and shapes of anions, e.g. tetrahedral oxyanions, one might expect analogous selectivity rules to emanate from receptors utilizing the noncovalent bonds discussed here. But the list of applications is far more broad. Clearly, the preferred arrangement of molecules around a given anion will have profound implications on crystal structures. Due to the preponderance of anions in biological systems, e.g. the phosphate anions that surround a DNA molecule or the carboxylate of the Asp residue, the principles involved in anion coordination are important in understanding such fundamental biological processes as DNA expression and enzyme catalysis. Indeed, in the simpler chemical reactions that involve anions at one stage or another, understanding of their coordination will inform a full exploration of the entire reaction.

\section{Acknowledgements}

This work was financed in part by a statutory activity subsidy from the Polish Ministry of Science and Higher Education for the Faculty of Chemistry of Wroclaw University of Science and Technology. 


\section{REFERENCES}

[1] T.L. Huyen, L.V. Duong, M.T. Nguyen, M.C. Lin, Int J Chem Kinet, 51 (2019) 610-617.

[2] J.T. Muya, B.R. Meher, S.C. Sahoo, H. Chung, Int J Quantum Chem, 119 (2019) e25929.

[3] I.D. Saenz-Tavera, V.M. Rosas-Garcia, Phys Chem Chem Phys, 21 (2019) 5744-5758.

[4] A. Karton, M. Brunner, M.J. Howard, G.G. Warr, R. Atkin, Acs Sustain Chem Eng, 6 (2018)

4115-4121.

[5] A.N. Isaev, Comput Theor Chem, 1117 (2017) 141-149.

[6] F. Groenewald, H.G. Raubenheimer, J. Dillen, C. Esterhuysen, Dalton T, 46 (2017) 4960-

4967.

[7] T. Tian, X.L. Hu, P. Guan, X.Q. Ding, J Mol Liq, 225 (2017) 224-230.

[8] C. Trujillo, V. Previtali, I. Rozas, Theor Chem Acc, 135 (2016) 260.

[9] G. Pohl, L. Mones, L. Turi, Journal of Chemical Physics, 145 (2016) 164313.

[10] J.E. Del Bene, I. Alkorta, J. Elguero, Chem Phys Lett, 655 (2016) 115-119.

[11] X. Liu, J.X. Zhang, L. Yang, R. Sun, Journal of Physical Chemistry A, 120 (2016) 37403746.

[12] T.D. Della, C.H. Suresh, Phys Chem Chem Phys, 18 (2016) 14588-14602.

[13] S.A.C. McDowell, Phys Chem Chem Phys, 20 (2018) 18420-18428.

[14] S.Y. Kucherov, S.F. Bureiko, G.S. Denisov, J Mol Struct, 1105 (2016) 246-255.

[15] S.J. Grabowski, J.M. Ugalde, D.M. Andrada, G. Frenking, Chem-Eur J, 22 (2016) 11317-

11328.

[16] B. Nepal, S. Scheiner, Chem-Eur J, 21 (2015) 1474-1481.

[17] I. Mata, E. Molins, I. Alkorta, E. Espinosa, Journal of Physical Chemistry A, 119 (2015)

183-194.

[18] Y.S. Chen, F. Wang, J Mol Model, 21 (2015) 38.

[19] T. Udagawa, T. Ishimoto, M. Tachikawa, Chem Phys, 441 (2014) 101-108.

[20] J.Y. Xi, X. Xu, Phys Chem Chem Phys, 18 (2016) 6913-6924.

[21] X. Wu, K. Tan, Z.C. Tang, X. Lu, Phys Chem Chem Phys, 16 (2014) 4771-4777.

[22] S. Jahangiri, L.M. Cai, G.H. Peslherbe, J Comput Chem, 35 (2014) 1707-1715.

[23] A. Jeppesen, B.E. Nielsen, D. Larsen, O.M. Akselsen, T.I. Solling, T. Brock-Nannestad, M.

Pittelkow, Org Biomol Chem, 15 (2017) 2784-2790.

[24] M. Marin-Luna, I. Alkorta, J. Elguero, O. Mo, M. Yanez, Molecules, 20 (2015) 9961-9976.

[25] Y.S. Chen, L.F. Yao, J Mol Model, 20 (2014) 2076.

[26] A. Bauza, D. Quinonero, P.M. Deya, A. Frontera, Journal of Physical Chemistry A, 117

(2013) 2651-2655.

[27] S. Scheiner, M. Michalczyk, W. Zierkiewicz, Chem Phys, 524 (2019) 55-62.

[28] S. Scheiner, M. Michalczyk, R. Wysokiński, W. Zierkiewicz, Chemical Physics (submitted), (2019).

[29] U. Adhikari, S. Scheiner, J. Phys. Chem. A, 118 (2014) 3183-3192.

[30] S. Scheiner, J. Phys. Chem. A, 119 (2015) 9189-9199.

[31] M. Liu, Q. Li, S. Scheiner, Phys. Chem. Chem. Phys., 19 (2017) 5550-5559.

[32] Y.-H. Wang, Y.-X. Lu, J.-W. Zou, Q.-S. Yu, Int. J. Quantum Chem., 108 (2008) 90-99.

[33] J.E. Del Bene, I. Alkorta, J. Elguero, Chem. Phys. Lett., 655-656 (2016) 115-119.

[34] D.M. Ivanov, M.A. Kinzhalov, A.S. Novikov, I.V. Ananyev, A.A. Romanova, V.P.

Boyarskiy, M. Haukka, V.Y. Kukushkin, Cryst. Growth Des., 17 (2017) 1353-1362.

[35] A. Bauzá, I. Alkorta, A. Frontera, J. Elguero, J. Chem. Theory Comput., 9 (2013) 52015210 . 
[36] E. Alikhani, F. Fuster, B. Madebene, S.J. Grabowski, Phys. Chem. Chem. Phys., 16 (2014) 2430-2442.

[37] N.A. Semenov, A.V. Lonchakov, N.A. Pushkarevsky, E.A. Suturina, V.V. Korolev, E. Lork, V.G. Vasiliev, S.N. Konchenko, J. Beckmann, N.P. Gritsan, A.V. Zibarev, Organometallics, 33 (2014) 4302-4314.

[38] D. Quiñonero, Molecules, 20 (2015) 11632.

[39] N.A. Semenov, D.E. Gorbunov, M.V. Shakhova, G.E. Salnikov, I.Y. Bagryanskaya, V.V. Korolev, J. Beckmann, N.P. Gritsan, A.V. Zibarev, Chem. Eur. J., 24 (2018) 12983-12991. [40] R. Kumar, D.K. Maity, Int. J. Quantum Chem., 119 (2019) e25855.

[41] M.D. Esrafili, F. Mohammadian-Sabet, Chem. Phys. Lett., 667 (2017) 337-344.

[42] A. Bauzá, A. Frontera, Chemphyschem, 18 (2017) 2191-2196.

[43] M. Liu, Q. Li, J. Cheng, W. Li, H.-B. Li, J. Chem. Phys., 145 (2016) 224310.

[44] X. García-Llinás, A. Bauzá, S.K. Seth, A. Frontera, J. Phys. Chem. A, 121 (2017) 53715376.

[45] M.D. Esrafili, S. Asadollahi, P. Mousavian, Chem. Phys. Lett., 691 (2018) 394-400.

[46] M. Esrafili, P. Mousavian, Molecules, 23 (2018) 2642.

[47] J.L. Casals-Sainz, A.C. Castro, E. Francisco, Á.M. Pendás, Molecules, 24 (2019) 2204.

[48] E. Bartashevich, Y. Matveychuk, V. Tsirelson, Molecules, 24 (2019) 1083.

[49] A. Bauzá, S.K. Seth, A. Frontera, Coord. Chem. Rev., 384 (2019) 107-125.

[50] A. Franconetti, A. Frontera, Chem. Eur. J., 25 (2019) 6007-6013.

[51] Y. Lu, H. Li, X. Zhu, W. Zhu, H. Liu, J. Phys. Chem. A, 115 (2011) 4467-4475.

[52] Y. Zhang, N. Ma, W. Wang, Chem. Phys. Lett., 532 (2012) 27-30.

[53] A. Bauzá, R. Ramis, A. Frontera, J. Phys. Chem. A, 118 (2014) 2827-2834.

[54] B. Galmés, D. Martínez, M.F. Infante-Carrió, A. Franconetti, A. Frontera, ChemPhysChem., 20 (2019) 1135-1144.

[55] M.D. Esrafili, S. Qasemsolb, Struct. Chem., 28 (2017) 1255-1264.

[56] M.D. Esrafili, P. Mousavian, Mol. Phys., 116 (2018) 388-398.

[57] A. Frontera, A. Bauza, Phys. Chem. Chem. Phys., 19 (2017) 30063-30068.

[58] A. Bauzá, A. Frontera, Angewandte Chemie International Edition, 54 (2015) 7340-7343.

[59] O. Grounds, M. Zeller, S.V. Rosokha, New J. Chem., 42 (2018) 10572-10583.

[60] M.G. Sarwar, B. Dragisic, L.J. Salsberg, C. Gouliaras, M.S. Taylor, J. Am. Chem. Soc., 132 (2010) 1646-1653.

[61] M. Domagała, A. Lutyńska, M. Palusiak, J. Phys. Chem. A, 122 (2018) 5484-5492.

[62] Q.-C. Shi, Y.-X. Lu, J.-C. Fan, J.-W. Zou, Y.-H. Wang, J. Mol. Struct. Theochem, 853

(2008) 39-44.

[63] F.F. Awwadi, R.D. Willett, B. Twamley, J. Mol. Struct., 918 (2009) 116-122.

[64] P. Cauliez, V. Polo, T. Roisnel, R. Llusar, M. Fourmigué, CrystEngComm, 12 (2010) 558566.

[65] J. Viger-Gravel, S. Leclerc, I. Korobkov, D.L. Bryce, J. Am. Chem. Soc., 136 (2014) 69296942.

[66] S.V. Rosokha, C.L. Stern, M.K. Vinakos, CrystEngComm, 18 (2016) 488-495.

[67] Y. Chen, L. Yao, X. Lin, Comput. Theor. Chem., 1036 (2014) 44-50.

[68] Y.Z. Liu, K. Yuan, L. Liu, Z. Yuan, Y.C. Zhu, Journal of Physical Chemistry A, 121 (2017) 892-900.

[69] M. Zurro, S. Asmus, J. Bamberger, S. Beckendorf, O.G. Mancheno, Chem-Eur J, 22 (2016) 3785-3793. 
[70] M. Toure, L. Charles, C. Chendo, S. Viel, O. Chuzel, J.L. Parrain, Chem-Eur J, 22 (2016) 8937-8942.

[71] V. Amendola, G. Bergamaschi, M. Boiocchi, L. Legnani, E. Lo Presti, A. Miljkovic, E. Monzani, F. Pancotti, Chem Commun, 52 (2016) 10910-10913.

[72] P.A. Gale, R. Quesada, Coordin Chem Rev, 250 (2006) 3219-3244.

[73] H. Ihm, S. Yun, H.G. Kim, J.K. Kim, K.S. Kim, Organic Letters, 4 (2002) 2897-2900.

[74] K. Sato, S. Arai, T. Yamagishi, Tetrahedron Lett, 40 (1999) 5219-5222.

[75] L. Nie, Z. Li, J. Han, X. Zhang, R. Yang, W.-X. Liu, F.-Y. Wu, J.-W. Xie, Y.-F. Zhao, Y.B. Jiang, J. Org. Chem., 69 (2004) 6449-6454.

[76] J.W. Steed, Chem. Soc. Rev., 39 (2010) 3686-3699.

[77] A.-F. Li, J.-H. Wang, F. Wang, Y.-B. Jiang, Chem. Soc. Rev., 39 (2010) 3729-3745.

[78] Z. Zhang, P.R. Schreiner, Chem. Soc. Rev., 38 (2009) 1187-1198.

[79] A. Nehra, S. Bandaru, D.S. Yarramala, C.P. Rao, Chem. Eur. J., 22 (2016) 8903-8914.

[80] E.A. Kataev, C. Müller, G.V. Kolesnikov, V.N. Khrustalev, Eur. J. Org. Chem., 2014

(2014) 2747-2753.

[81] H.Y. Kuchelmeister, C. Schmuck, Chem. Eur. J., 17 (2011) 5311-5318.

[82] M.J. Langton, C.J. Serpell, P.D. Beer, Angew. Chem. Int. Ed., 55 (2016) 1974-1987.

[83] M.G. Sarwar, B. Dragisic, S. Sagoo, M.S. Taylor, Angew. Chem. Int. Ed., 49 (2010) 16741677.

[84] E. Dimitrijevic, O. Kvak, M.S. Taylor, Chem. Commun., 466 (2010) 9025-9027.

[85] M.G. Chudzinski, C.A. McClary, M.S. Taylor, J. Am. Chem. Soc., 133 (2011) 1055910567.

[86] M.G. Sarwar, B. Dragisic, E. Dimitrijevic, M.S. Taylor, Chem. Eur. J., 19 (2013) 20502058.

[87] A. Caballero, N.G. White, P.D. Beer, Angew. Chem., Int. Ed. Engl., 50 (2011) 1845-1848.

[88] S.M. Walter, F. Kniep, E. Herdtweck, S.M. Huber, Angew. Chem. Int. Ed., 50 (2011) 71877191.

[89] L.C. Gilday, N.G. White, P.D. Beer, Dalton Trans., 42 (2013) 15766-15773.

[90] A. Caballero, L. Swan, F. Zapata, P.D. Beer, Angew. Chem. Int. Ed., 53 (2014) 1185411858.

[91] J.M. Mercurio, R.C. Knighton, J. Cookson, P.D. Beer, Chem. Eur. J., 20 (2014) 1174011749.

[92] T.K. Mole, W.E. Arter, I. Marques, V. Félix, P.D. Beer, J. Organomet. Chem., 792 (2015) 206-210.

[93] B. Chowdhury, S. Sinha, P. Ghosh, Chem. Eur. J., 22 (2016) 18051-18059.

[94] S.P. Cornes, M.R. Sambrook, P.D. Beer, Chem. Commun., 53 (2017) 3866-3869.

[95] T.A. Barendt, A. Docker, I. Marques, V. Félix, P.D. Beer, Angew. Chem. Int. Ed., 55

(2016) 11069-11076.

[96] A. Borissov, J.Y.C. Lim, A. Brown, K.E. Christensen, A.L. Thompson, M.D. Smith, P.D.

Beer, Chem. Commun., 53 (2017) 2483-2486.

[97] H.A. Klein, P.D. Beer, Chem. Eur. J., 25 (2019) 3125-3130.

[98] J.Y.C. Lim, T. Bunchuay, P.D. Beer, Chem. Eur. J., 23 (2017) 4700-4707.

[99] S. Chakraborty, S. Maji, R. Ghosh, R. Jana, A. Datta, P. Ghosh, Chem. Commun., 55 (2019) 1506-1509.

[100] J.Y.C. Lim, I. Marques, V. Félix, P.D. Beer, Angew. Chem. Int. Ed., 57 (2018) 584-588. [101] J.Y.C. Lim, P.D. Beer, New J. Chem., 42 (2018) 10472-10475. 
[102] S.M. Walter, F. Kniep, L. Rout, F.P. Schmidtchen, E. Herdtweck, S.M. Huber, J. Am. Chem. Soc., 134 (2012) 8507-8512.

[103] S.H. Jungbauer, S.M. Huber, J. Am. Chem. Soc., 137 (2015) 12110-12120.

[104] N. Schulz, P. Sokkar, E. Engelage, S. Schindler, M. Erdelyi, E. Sanchez-Garcia, S.M. Huber, Chem. Eur. J., 24 (2018) 3464-3473.

[105] F. Heinen, E. Engelage, A. Dreger, R. Weiss, S.M. Huber, Angew. Chem. Int. Ed., 57 (2018) 3830-3833.

[106] A. Caballero, F. Zapata, N.G. White, P.J. Costa, V. Félix, P.D. Beer, Angew. Chem. Int. Ed., 51 (2012) 1876-1880.

[107] F. Zapata, A. Caballero, N.G. White, T.D.W. Claridge, P.J. Costa, V. Félix, P.D. Beer, J. Am. Chem. Soc., 134 (2012) 11533-11541.

[108] P. Sabater, F. Zapata, A. Caballero, N. de la Visitación, I. Alkorta, J. Elguero, P. Molina, J. Org. Chem., 81 (2016) 7448-7458.

[109] R. Tepper, B. Schulze, M. Jäger, C. Friebe, D.H. Scharf, H. Görls, U.S. Schubert, J. Org. Chem., 80 (2015) 3139-3150.

[110] N.B. Wageling, G.F. Neuhaus, A.M. Rose, D.A. Decato, O.B. Berryman, Supra. Chem., 28 (2016) 665-672.

[111] C.J. Massena, N.B. Wageling, D.A. Decato, E. Martin Rodriguez, A.M. Rose, O.B.

Berryman, Angew. Chem. Int. Ed., 55 (2016) 12398-12402.

[112] F. Zapata, L. González, A. Caballero, A. Bastida, D. Bautista, P. Molina, J. Am. Chem. Soc., 140 (2018) 2041-2045.

[113] A. Dreger, E. Engelage, B. Mallick, P.D. Beer, S.M. Huber, Chem. Commun., 54 (2018) 4013-4016.

[114] A.M.S. Riel, D.A. Decato, J. Sun, C.J. Massena, M.J. Jessop, O.B. Berryman, Chem. Sci., 9 (2018) 5828-5836.

[115] J.A. Lohrman, C.-L. Deng, T.A. Shear, L.N. Zakharov, M.M. Haley, D.W. Johnson, Chem. Commun., 55 (2019) 1919-1922.

[116] D. Mungalpara, S. Stegmuller, S. Kubik, Chem. Commun., 53 (2017) 5095-5098.

[117] G.E. Garrett, G.L. Gibson, R.N. Straus, D.S. Seferos, M.S. Taylor, J. Am. Chem. Soc., 137 (2015) 4126-4133.

[118] G.E. Garrett, E.I. Carrera, D.S. Seferos, M.S. Taylor, Chem. Commun., 52 (2016) 98819884.

[119] S. Benz, M. Macchione, Q. Verolet, J. Mareda, N. Sakai, S. Matile, J. Am. Chem. Soc., 138 (2016) 9093-9096.

[120] J.Y.C. Lim, I. Marques, A.L. Thompson, K.E. Christensen, V. Félix, P.D. Beer, J. Am. Chem. Soc., 139 (2017) 3122-3133.

[121] J.Y.C. Lim, J.Y. Liew, P.D. Beer, Chem. Eur. J., 24 (2018) 14560-14566.

[122] J.Y.C. Lim, I. Marques, V. Félix, P.D. Beer, Chem. Commun., 54 (2018) 10851-10854.

[123] A. Borissov, I. Marques, J.Y.C. Lim, V. Félix, M.D. Smith, P.D. Beer, J. Am. Chem. Soc., 141 (2019) 4119-4129.

[124] A.C. Tagne Kuate, M.M. Naseer, K. Jurkschat, Chem. Commun., 53 (2017) 2013-2015.

[125] M.M. Naseer, K. Jurkschat, Chem. Commun., 53 (2017) 8122-8135.

[126] L.M. Lee, M. Tsemperouli, A.I. Poblador-Bahamonde, S. Benz, N. Sakai, K. Sugihara, S. Matile, J. Am. Chem. Soc., 141 (2019) 810-814.

[127] M.J. Langton, C.J. Serpell, P.D. Beer, Angew. Chem. Int. Ed., 55 (2016) 1974-1987.

[128] H. Wang, W. Wang, W.J. Jin, Chem. Rev., 116 (2016) 5072-5104. 
[129] A. Brown, P.D. Beer, Chem. Commun., 52 (2016) 8645-8658.

[130] P. Molina, F. Zapata, A. Caballero, Chem. Rev., 117 (2017) 9907-9972.

[131] J.Y.C. Lim, P.D. Beer, Chem-Us, 4 (2018) 731-783.

[132] B. Nepal, S. Scheiner, Chem. Eur. J., 21 (2015) 13330-13335.

[133] B. Nepal, S. Scheiner, J. Phys. Chem. A, 119 (2015) 13064-13073.

[134] B. Nepal, S. Scheiner, ChemPhysChem., 17 (2016) 836-844.

[135] S. Scheiner, Chem. Eur. J., 22 (2016) 18850-18858.

[136] G. Sánchez-Sanz, C. Trujillo, J. Phys. Chem. A, 122 (2018) 1369-1377.

[137] S. Scheiner, J. Phys. Chem. A, 121 (2017) 3606-3615.

[138] S. Scheiner, Faraday Disc., 203 (2017) 213-226.

[139] A.O. Ortolan, G.F. Caramori, F. Matthias Bickelhaupt, R.L.T. Parreira, A. Munoz-Castro, T. Kar, Phys. Chem. Chem. Phys., 19 (2017) 24696-24705.

[140] H.A. Samimi, M.D. Esrafili, F. Mohammadian-Sabet, H. Haddadi, Mol Phys, 113 (2015) 1442-1450.

[141] N.A. Pushkarevsky, E.A. Chulanova, L.A. Shundrin, A.I. Smolentsev, G.E. Salnikov, E.A. Pritchina, A.M. Genaev, I.G. Irtegova, I.Y. Bagryanskaya, S.N. Konchenko, N.P. Gritsan, J. Beckmann, A.V. Zibarev, Chem-Eur J, 25 (2019) 806-816.

[142] S. Scheiner, Molecules, 24 (2019) 227.

[143] S. Scheiner, Molecules, 23 (2018) 1147.

[144] A. Bauza, R. Ramis, A. Frontera, Comput Theor Chem, 1038 (2014) 67-70.

[145] C. Trujillo, G. Sanchez-Sanz, I. Alkorta, J. Elguero, Chemphyschem, 15 (2014) 34933501 .

[146] D. Setiawan, D. Cremer, Chem Phys Lett, 662 (2016) 182-187.

[147] R. Nunes, P.J. Costa, Chem-Asian J, 12 (2017) 586-594.

[148] S. Ruiz-Botella, P. Vidossich, G. Ujaque, E. Peris, P.D. Beer, Rsc Adv, 7 (2017) 1125311258.

[149] A. Bauza, A. Frontera, Phys Chem Chem Phys, 19 (2017) 12936-12941.

[150] B.B. Cao, S.Y. Liu, D.M. Du, Z.M. Xue, H. Fu, H.T. Sun, J Mol Graph Model, 64 (2016) 51-59.

[151] Y.S. Chen, Journal of Physical Chemistry A, 117 (2013) 8081-8090. 
Table 1 Calculated binding energies between anion and a single ligand in H-bonded clusters.

\begin{tabular}{|c|c|c|c|c|}
\hline anion & ligand & $\begin{array}{c}-\mathrm{E}_{\mathrm{b}}, \\
\mathrm{kcal} / \mathrm{mol}\end{array}$ & level of theory & reference \\
\hline \multicolumn{5}{|c|}{ monoatomic anion } \\
\hline $\mathrm{F}^{-}$ & $\mathrm{HF}$ & $181.7^{\mathrm{b}}$ & $\begin{array}{c}\text { CCSD }(\mathrm{T}) / \mathrm{aug} \text {-cc- } \\
\text { pVTZ }\end{array}$ & 142 \\
\hline $\mathrm{F}^{-}$ & $\left(\mathrm{CH}_{3}\right)_{2} \mathrm{Se}$ & $79.5^{\mathrm{a}}$ & MP2/6-311++G(d,p) & 47 \\
\hline $\mathrm{F}^{-}$ & $\left(\mathrm{CH}_{3}\right)_{2} \mathrm{~S}$ & $74.3^{\mathrm{a}}$ & MP2/6-311++G(d,p) & 47 \\
\hline $\mathrm{F}^{-}$ & $\left(\mathrm{CH}_{3}\right)_{2} \mathrm{O}$ & $58.6^{\mathrm{a}}$ & MP2/6-311++G(d,p) & 47 \\
\hline $\mathrm{F}^{-}$ & $\mathrm{CFH}_{3}$ & 55.7 & MP2/aug'-cc-pVTZ & 141 \\
\hline $\mathrm{F}^{-}$ & $\mathrm{CF}_{4}$ & 26.8 & MP2/aug'-cc-pVTZ & 141 \\
\hline $\mathrm{F}^{-}$ & $\mathrm{CF}_{3} \mathrm{H}$ & 26.15 & MP2/aug-cc-pVDZ & 49 \\
\hline $\mathrm{Cl}^{-}$ & {$\left[\mathrm{Co}\left(\mathrm{NH}_{3}\right)_{5} \mathrm{NO}_{2}\right]^{2+}$} & $199.33^{\mathrm{a}}$ & MP2/6-31+G(d,p) & 39 \\
\hline $\mathrm{Cl}^{-}$ & $\mathrm{HCl}$ & $125.7^{\mathrm{b}}$ & $\begin{array}{c}\text { CCSD(T)/aug-cc- } \\
\text { pVTZ }\end{array}$ & 142 \\
\hline $\mathrm{Cl}^{-}$ & squaramide & $70^{\mathrm{a}}$ & B3LYP/MidiX & 44 \\
\hline $\mathrm{Cl}^{-}$ & croconamide & $68^{\mathrm{a}}$ & B3LYP/MidiX & 44 \\
\hline $\mathrm{Cl}^{-}$ & thiourea & $64^{\mathrm{a}}$ & B3LYP/MidiX & 44 \\
\hline $\mathrm{Cl}^{-}$ & $\mathrm{CClH}_{3}$ & 45.2 & MP2/aug'-cc-pVTZ & 141 \\
\hline $\mathrm{Cl}^{-}$ & $\mathrm{HF}$ & $23.1^{\mathrm{a}}$ & MP2/aug-cc-pVTZ & 10 \\
\hline $\mathrm{Cl}^{-}$ & $\mathrm{CClF}_{3}$ & 17.6 & MP2/aug'-cc-pVTZ & 141 \\
\hline $\mathrm{Cl}^{-}$ & $\mathrm{CF}_{3} \mathrm{H}$ & 15.16 & MP2/aug-cc-pVDZ & 49 \\
\hline $\mathrm{Cl}^{-}$ & triazine & 9.70 & MP2/aug-cc-pVTZ & 43 \\
\hline $\mathrm{Br}^{-}$ & $\mathrm{HBr}$ & $109.9^{b}$ & $\begin{array}{c}\text { CCSD(T)/aug-cc- } \\
\text { pVTZ }\end{array}$ & 142 \\
\hline $\mathrm{Br}^{-}$ & squaramide & $59^{\mathrm{a}}$ & B3LYP/MidiX & 44 \\
\hline $\mathrm{Br}^{-}$ & croconamide & $57^{\mathrm{a}}$ & B3LYP/MidiX & 44 \\
\hline $\mathrm{Br}^{-}$ & thiourea & $54^{\mathrm{a}}$ & B3LYP/MidiX & 44 \\
\hline $\mathrm{Br}^{-}$ & $\mathrm{HF}$ & $18.7^{\mathrm{a}}$ & MP2/aug-cc-pVTZ & 10 \\
\hline $\mathrm{Br}^{-}$ & $\mathrm{CF}_{3} \mathrm{H}$ & 13.19 & MP2/aug-cc-pVDZ & 49 \\
\hline $\mathrm{Br}^{-}$ & triazine & 8.22 & MP2/aug-cc-pVTZ & 43 \\
\hline $\mathrm{I}^{-}$ & $\mathrm{HI}$ & $92.1^{b}$ & $\begin{array}{c}\text { CCSD(T)/aug-cc- } \\
\text { pVTZ }\end{array}$ & 142 \\
\hline $\mathrm{I}^{-}$ & squaramide & $42^{\mathrm{a}}$ & B3LYP/MidiX & 44 \\
\hline $\mathrm{I}^{-}$ & croconamide & $39^{\mathrm{a}}$ & B3LYP/MidiX & 44 \\
\hline $\mathrm{I}^{-}$ & thiourea & $38^{\mathrm{a}}$ & B3LYP/MidiX & 44 \\
\hline $\mathrm{I}^{-}$ & triazine & 6.55 & MP2/aug-cc-pVTZ & 43 \\
\hline $\mathrm{Au}^{-}$ & $\mathrm{HF}$ & $23.4^{\mathrm{a}}$ & MP2/aug-cc-pVTZ & 37 \\
\hline $\mathrm{Au}^{-}$ & $\mathrm{HCN}$ & $21.6^{\mathrm{a}}$ & MP2/aug-cc-pVTZ & 37 \\
\hline
\end{tabular}




\begin{tabular}{|c|c|c|c|c|}
\hline $\mathrm{Au}^{-}$ & $\mathrm{H}_{2} \mathrm{O}$ & $15.1^{\mathrm{a}}$ & MP2/aug-cc-pVTZ & 37 \\
\hline $\mathrm{Au}^{-}$ & $\mathrm{HCCH}$ & $10.3^{\mathrm{a}}$ & MP2/aug-cc-pVTZ & 37 \\
\hline $\mathrm{Au}^{-}$ & $\mathrm{NH}_{3}$ & $8.9^{\mathrm{a}}$ & MP2/aug-cc-pVTZ & 37 \\
\hline $\mathrm{Au}^{-}$ & $\mathrm{CH}_{4}$ & $2.9^{\mathrm{a}}$ & MP2/aug-cc-pVTZ & 37 \\
\hline \multicolumn{5}{|c|}{ polyatomic anion } \\
\hline $\mathrm{NO}_{3}{ }^{-}$ & {$\left[\mathrm{Co}\left(\mathrm{NH}_{3}\right)_{5} \mathrm{NO}_{2}\right]^{2+}$} & $193.25^{\mathrm{a}}$ & MP2/6-31+G(d,p) & 39 \\
\hline $\mathrm{NO}_{3}{ }^{-}$ & tetraoxacalix[2]arene[2]triazine & 30.48 & MP2/aug-cc-pVDZ & 45 \\
\hline $\mathrm{NO}_{3}{ }^{-}$ & $\mathrm{CF}_{3} \mathrm{H}$ & 14.48 & MP2/aug-cc-pVDZ & 49 \\
\hline $\mathrm{NO}_{3}{ }^{-}$ & $\mathrm{H}_{2} \mathrm{O}$ & 13.2 & MP2/aug-cc-pVTZ & 138 \\
\hline $\mathrm{PO}_{4}^{3-}$ & $\mathrm{CF}_{3} \mathrm{H}$ & 44.55 & MP2/aug-cc-pVDZ & 49 \\
\hline $\mathrm{HPO}_{4}^{2-}$ & $\mathrm{H}_{2} \mathrm{O}$ & 28.2 & MP2/aug-cc-pVTZ & 138 \\
\hline $\mathrm{HPO}_{4}{ }^{2-}$ & $\mathrm{CF}_{3} \mathrm{H}$ & 27.55 & MP2/aug-cc-pVDZ & 49 \\
\hline $\mathrm{SO}_{4}{ }^{2-}$ & $\mathrm{CF}_{3} \mathrm{H}$ & 26.70 & MP2/aug-cc-pVDZ & 49 \\
\hline $\mathrm{SO}_{4}{ }^{2-}$ & $\mathrm{H}_{2} \mathrm{O}$ & 26.3 & MP2/aug-cc-pVTZ & 138 \\
\hline $\mathrm{CH}_{3} \mathrm{COO}^{-}$ & $\mathrm{CF}_{3} \mathrm{H}$ & 16.66 & MP2/aug-cc-pVDZ & 49 \\
\hline $\mathrm{CH}_{3} \mathrm{COO}^{-}$ & $\mathrm{H}_{2} \mathrm{O}$ & 16.5 & MP2/aug-cc-pVTZ & 138 \\
\hline $\mathrm{SCN}^{-}$ & tetraoxacalix[2]riazine & 25.19 & MP2/aug-cc-pVDZ & 45 \\
\hline $\mathrm{SCN}^{-}$ & $\mathrm{H}_{2} \mathrm{O}$ & 11.3 & MP2/aug-cc-pVTZ & 138 \\
\hline $\mathrm{H}_{3} \mathrm{C}^{-}$ & $\mathrm{F}_{3} \mathrm{CH}$ & 12.46 & MP2/aug-cc-pVTZ & 140 \\
\hline $\mathrm{H}_{3} \mathrm{C}^{-}$ & $\mathrm{HNH}_{2}$ & 10.50 & MP2/aug-cc-pVTZ & 140 \\
\hline $\mathrm{H}_{3} \mathrm{C}^{-}$ & $\mathrm{H}_{2} \mathrm{NH}$ & 6.57 & MP2/aug-cc-pVTZ & 140 \\
\hline $\mathrm{H}_{3} \mathrm{C}^{-}$ & $\mathrm{H}_{3} \mathrm{CH}$ & 1.50 & MP2/aug-cc-pVTZ & 140 \\
\hline $\mathrm{CO}_{3}^{2-}$ & $\mathrm{H}_{2} \mathrm{O}$ & 34.2 & MP2/aug-cc-pVTZ & 138 \\
\hline $\mathrm{BF}_{4}^{-}$ & tetraoxacalix[2]arene[2]triazine & 22.31 & MP2/aug-cc-pVDZ & 45 \\
\hline $\mathrm{OH}^{-}$ & $\mathrm{H}_{2} \mathrm{O}$ & 20.45 & MP2/aug-cc-pVTZ & 140 \\
\hline $\mathrm{HCC}^{-}$ & $\mathrm{H}_{2} \mathrm{O}$ & 17.50 & MP2/aug-cc-pVTZ & 140 \\
\hline $\mathrm{F}_{3} \mathrm{C}^{-}$ & $\mathrm{H}_{2} \mathrm{O}$ & 16.78 & MP2/aug-cc-pVTZ & 140 \\
\hline $\mathrm{PF}_{6}{ }^{-}$ & tetraoxacalix[2]arene[2]triazine & 16.33 & MP2/aug-cc-pVDZ & 45 \\
\hline $\mathrm{HCOO}^{-}$ & $\mathrm{CF}_{3} \mathrm{H}$ & 16.26 & MP2/aug-cc-pVDZ & 49 \\
\hline $\mathrm{CN}^{-}$ & $\mathrm{CF}_{3} \mathrm{H}$ & 14.89 & MP2/aug-cc-pVDZ & 49 \\
\hline $\mathrm{H}_{2} \mathrm{PO}_{4}^{-}$ & $\mathrm{CF}_{3} \mathrm{H}$ & 13.76 & MP2/aug-cc-pVDZ & 49 \\
\hline $\mathrm{HSO}_{4}{ }^{-}$ & $\mathrm{CF}_{3} \mathrm{H}$ & 12.31 & MP2/aug-cc-pVDZ & 49 \\
\hline $\mathrm{H}_{2} \mathrm{FC}^{-}$ & $\mathrm{HNH}_{2}$ & 10.63 & MP2/aug-cc-pVTZ & 140 \\
\hline $\mathrm{ClO}_{4}^{-}$ & $\mathrm{H}_{2} \mathrm{O}$ & 10.2 & MP2/aug-cc-pVTZ & 138 \\
\hline $\mathrm{HF}_{2} \mathrm{C}^{-}$ & $\mathrm{HNH}_{2}$ & 10.10 & MP2/aug-cc-pVTZ & 140 \\
\hline $\mathrm{F}_{3} \mathrm{C}^{-}$ & $\mathrm{HNH}_{2}$ & 8.26 & MP2/aug-cc-pVTZ & 140 \\
\hline
\end{tabular}

a interaction energy

${ }^{\mathrm{b}}$ bond dissociation energies 
Table 2 Calculated binding energies between monoatomic anion and a single ligand in tetrel bonded clusters.

\begin{tabular}{|c|c|c|c|c|}
\hline anion & ligand & $-\mathrm{E}_{\mathrm{bin}}, \mathrm{kcal} / \mathrm{mol}$ & level of theory & reference \\
\hline $\mathrm{F}^{-}$ & $\mathrm{SiF}_{3}-\mathrm{ImF}_{3}-\mathrm{Bz}-\mathrm{ImF}_{3}-\mathrm{SiF}_{3}{ }^{2+}$ & 251.50 & M06-2X/aug-cc-pVDZ & 137 \\
\hline $\mathrm{F}^{-}$ & $\mathrm{SiF}_{3}-\mathrm{ImF}_{-\mathrm{Bz}}-\mathrm{ImF}_{-} \mathrm{SiF}_{3}{ }^{2+}$ & 242.79 & M06-2X/aug-cc-pVDZ & 137 \\
\hline $\mathrm{F}^{-}$ & $\mathrm{SiF}_{3}-\mathrm{Im}-\mathrm{Bz}-\mathrm{Im}-\mathrm{SiF}_{3}{ }^{2+}$ & 231.65 & M06-2X/aug-cc-pVDZ & 137 \\
\hline $\mathrm{F}^{-}$ & $\mathrm{SnH}_{3}-\mathrm{ImF}_{3}-\mathrm{Bz}-\mathrm{ImF}_{3}-\mathrm{SnH}_{3}{ }^{2+}$ & 223.88 & M06-2X/aug-cc-pVDZ & 137 \\
\hline $\mathrm{F}^{-}$ & $\mathrm{H}-\mathrm{ImF}_{3}-\mathrm{Bz}-\mathrm{ImF}_{3}-\mathrm{H}^{2+}$ & 221.16 & M06-2X/aug-cc-pVDZ & 137 \\
\hline $\mathrm{F}^{-}$ & $\mathrm{SnH}_{3}-\mathrm{ImF}-\mathrm{Bz}-\mathrm{ImF}-\mathrm{SnH}_{3}{ }^{2+}$ & 216.83 & M06-2X/aug-cc-pVDZ & 137 \\
\hline $\mathrm{F}^{-}$ & H-ImF-Bz-ImF-H ${ }^{2+}$ & 212.86 & M06-2X/aug-cc-pVDZ & 137 \\
\hline $\mathrm{F}^{-}$ & I-ImF $3-B z-I_{3} F_{3}-I^{2+}$ & 209.58 & M06-2X/aug-cc-pVDZ & 137 \\
\hline $\mathrm{F}^{-}$ & $\mathrm{SnH}_{3}-\mathrm{Im}-\mathrm{Bz}-\mathrm{Im}-\mathrm{SnH}_{3}{ }^{2+}$ & 206.14 & M06-2X/aug-cc-pVDZ & 137 \\
\hline $\mathrm{F}^{-}$ & I-ImF-Bz-ImF-I ${ }^{2+}$ & 202.44 & M06-2X/aug-cc-pVDZ & 137 \\
\hline $\mathrm{F}^{-}$ & H-Im-Bz-Im-H ${ }^{2+}$ & 196.57 & M06-2X/aug-cc-pVDZ & 137 \\
\hline $\mathrm{F}^{-}$ & I-Im-Bz-Im-I ${ }^{2+}$ & 191.17 & M06-2X/aug-cc-pVDZ & 137 \\
\hline $\mathrm{F}^{-}$ & $\mathrm{Im}-\mathrm{SiF}_{3}^{+}$ & 175.13 & M06-2X/aug-cc-pVDZ & 137 \\
\hline $\mathrm{F}^{-}$ & $\mathrm{Im}_{-} \mathrm{SnH}_{3}^{+}$ & 142.06 & M06-2X/aug-cc-pVDZ & 137 \\
\hline $\mathrm{F}^{-}$ & $\mathrm{Im}-\mathrm{H}^{+}$ & 130.09 & M06-2X/aug-cc-pVDZ & 137 \\
\hline $\mathrm{F}^{-}$ & $\mathrm{Im}^{\mathrm{Im}} \mathrm{I}^{+}$ & 126.01 & M06-2X/aug-cc-pVDZ & 137 \\
\hline $\mathrm{F}^{-}$ & $\mathrm{SnF}_{3} \mathrm{CN}$ & $96.30^{\mathrm{b}}$ & MP2/aug-cc-pVDZ & 46 \\
\hline $\mathrm{F}^{-}$ & $\mathrm{SnF}_{4}$ & $93.58^{\mathrm{b}}$ & MP2/aug-cc-pVDZ & 46 \\
\hline $\mathrm{F}^{-}$ & $\mathrm{GeF}_{3} \mathrm{CN}$ & $84.92^{\mathrm{b}}$ & MP2/aug-cc-pVDZ & 46 \\
\hline $\mathrm{F}^{-}$ & $\mathrm{SiF}_{3} \mathrm{CN}$ & $84.37^{\mathrm{b}}$ & MP2/aug-cc-pVDZ & 46 \\
\hline $\mathrm{F}^{-}$ & $\mathrm{SiF}_{3} \mathrm{CN}$ & $84.37^{\mathrm{b}}$ & MP2/aug-cc-pVTZ & 45 \\
\hline $\mathrm{F}^{-}$ & $\mathrm{GeF}_{4}$ & $79.17^{\mathrm{b}}$ & MP2/aug-cc-pVDZ & 46 \\
\hline $\mathrm{F}^{-}$ & $\mathrm{SiF}_{4}$ & $70.11^{\mathrm{b}}$ & MP2/aug-cc-pVDZ & 46 \\
\hline $\mathrm{F}^{-}$ & $\mathrm{SiF}_{4}$ & $70.11^{\mathrm{b}}$ & MP2/aug-cc-pVTZ & 45 \\
\hline $\mathrm{F}^{-}$ & Ge-receptor & 63.35 & M06-2X/aug-cc-pVDZ & 135 \\
\hline $\mathrm{F}^{-}$ & $\mathrm{SiH}_{4}$ & 60.17 & CCSD/aug-cc-pVTZ & 47 \\
\hline $\mathrm{F}^{-}$ & $\mathrm{GeH}_{4}$ & 40.17 & CCSD/aug-cc-pVTZ & 47 \\
\hline $\mathrm{F}^{-}$ & Sn-receptor & 30.11 & M06-2X/aug-cc-pVDZ & 138 \\
\hline $\mathrm{F}^{-}$ & Ge-receptor & 24.73 & M06-2X/aug-cc-pVDZ & 138 \\
\hline $\mathrm{F}^{-}$ & $\mathrm{CFH}_{3}$ & 13 & MP2/aug'-cc-pVTZ & 10 \\
\hline$\overline{\mathrm{F}^{-}}$ & $\mathrm{CF}_{3} \mathrm{CN}$ & $8.73^{\mathrm{b}}$ & MP2/aug-cc-pVTZ & 45 \\
\hline $\mathrm{F}^{-}$ & $\mathrm{CF}_{4}$ & 6 & MP2/aug'-cc-pVTZ & 10 \\
\hline $\mathrm{F}^{-}$ & $\mathrm{CF}_{4}$ & $5.84^{\mathrm{b}}$ & MP2/aug-cc-pVTZ & 45 \\
\hline $\mathrm{F}^{-}$ & $\mathrm{CH}_{4}$ & 3.42 & CCSD/aug-cc-pVTZ & 47 \\
\hline $\mathrm{Cl}^{-}$ & $\mathrm{SiF}_{3}-\mathrm{ImF}_{3}-\mathrm{Bz}-\mathrm{ImF}_{3}-\mathrm{SiF}_{3}{ }^{2+}$ & 127.57 & M06-2X/aug-cc-pVDZ & 137 \\
\hline $\mathrm{Cl}^{-}$ & $\mathrm{SiF}_{3}-\mathrm{ImF}-\mathrm{Bz}-\mathrm{ImF} \mathrm{SiF}_{3}{ }^{2+}$ & 124.88 & M06-2X/aug-cc-pVDZ & 137 \\
\hline $\mathrm{Cl}^{-}$ & $\mathrm{SnH}_{3}-\mathrm{ImF}_{3}-\mathrm{Bz}_{2}-\mathrm{ImF}_{3}-\mathrm{SnH}_{3}{ }^{2+}$ & 116.07 & M06-2X/aug-cc-pVDZ & 137 \\
\hline
\end{tabular}




\begin{tabular}{|c|c|c|c|c|}
\hline $\mathrm{Cl}^{-}$ & $\mathrm{I}-\mathrm{ImF}_{3}-\mathrm{Bz}-\mathrm{ImF}_{3}-\mathrm{I}^{2+}$ & 111.17 & M06-2X/aug-cc-pVDZ & 137 \\
\hline $\mathrm{Cl}^{-}$ & $\mathrm{H}-\mathrm{ImF}_{3}-\mathrm{Bz}-\mathrm{ImF}_{3}-\mathrm{H}^{2+}$ & 110.77 & M06-2X/aug-cc-pVDZ & 137 \\
\hline $\mathrm{Cl}^{-}$ & $\mathrm{SnH}_{3}-\mathrm{ImF}-\mathrm{Bz}-\mathrm{ImF}-\mathrm{SnH}_{3}{ }^{2+}$ & 109.33 & M06-2X/aug-cc-pVDZ & 137 \\
\hline $\mathrm{Cl}^{-}$ & $\mathrm{SiF}_{3}-\mathrm{Im}-\mathrm{Bz}-\mathrm{Im}-\mathrm{SiF}_{3}{ }^{2+}$ & 106.62 & M06-2X/aug-cc-pVDZ & 137 \\
\hline $\mathrm{Cl}^{-}$ & H-ImF-Bz-ImF-H ${ }^{2+}$ & 104.90 & M06-2X/aug-cc-pVDZ & 137 \\
\hline $\mathrm{Cl}^{-}$ & $\mathrm{I}^{-I m F-B z-I m F-I^{2+}}$ & 104.19 & M06-2X/aug-cc-pVDZ & 137 \\
\hline $\mathrm{Cl}^{-}$ & $\mathrm{SnH}_{3}-\mathrm{Im}-\mathrm{Bz}-\mathrm{Im}-\mathrm{SnH}_{3}{ }^{2+}$ & 99.08 & M06-2X/aug-cc-pVDZ & 137 \\
\hline $\mathrm{Cl}^{-}$ & H-Im-Bz-Im-H ${ }^{2+}$ & 97.89 & M06-2X/aug-cc-pVDZ & 137 \\
\hline $\mathrm{Cl}^{-}$ & I-Im-Bz-Im-I ${ }^{2+}$ & 93.45 & M06-2X/aug-cc-pVDZ & 137 \\
\hline $\mathrm{Cl}^{-}$ & TMHYZC $^{\mathrm{a}}$ & 82.67 & M06-2X/aug-cc-pVDZ & 48 \\
\hline $\mathrm{Cl}^{-}$ & VAPREJ $^{\mathrm{a}}$ & 81.80 & M06-2X/aug-cc-pVDZ & 48 \\
\hline $\mathrm{Cl}^{-}$ & GETQIF $^{\mathrm{a}}$ & 81.07 & M06-2X/aug-cc-pVDZ & 48 \\
\hline $\mathrm{Cl}^{-}$ & calix[4]pyrrol & 71.7 & BP86-D3/def2-TZVP & 144 \\
\hline $\mathrm{Cl}^{-}$ & LONGEB $^{\mathrm{a}}$ & 71.05 & M06-2X/aug-cc-pVDZ & 48 \\
\hline $\mathrm{Cl}^{-}$ & octamethyl calix[4]pyrrol derivative & 66.7 & BP86-D3/def2-TZVP & 144 \\
\hline $\mathrm{Cl}^{-}$ & tetramethyl calix[4]pyrrol derivative & 64.6 & BP86-D3/def2-TZVP & 144 \\
\hline $\mathrm{Cl}^{-}$ & $\mathrm{SnF}_{3} \mathrm{CN}$ & $64.11^{\mathrm{b}}$ & MP2/aug-cc-pVDZ & 46 \\
\hline $\mathrm{Cl}^{-}$ & $\mathrm{SnF}_{4}$ & $61.84^{\mathrm{b}}$ & MP2/aug-cc-pVDZ & 46 \\
\hline $\mathrm{Cl}^{-}$ & ortho & 56.45 & M06-2X/aug-cc-pVDZ & 142 \\
\hline $\mathrm{Cl}^{-}$ & ortho di $\mathrm{C} \equiv \mathrm{C}$ & 56.41 & M06-2X/aug-cc-pVDZ & 142 \\
\hline $\mathrm{Cl}^{-}$ & ortho $\mathrm{C} \equiv \mathrm{C}$ & 54.46 & M06-2X/aug-cc-pVDZ & 142 \\
\hline $\mathrm{Cl}^{-}$ & 1,3-cyclohex & 52.47 & M06-2X/aug-cc-pVDZ & 142 \\
\hline $\mathrm{Cl}^{-}$ & ZENJAD $^{\mathrm{a}}$ & 52.28 & M06-2X/aug-cc-pVDZ & 48 \\
\hline $\mathrm{Cl}^{-}$ & $\mathrm{Im}-\mathrm{SiF}_{3}^{+}$ & 52.13 & M06-2X/aug-cc-pVDZ & 137 \\
\hline $\mathrm{Cl}^{-}$ & octocycle & 48.14 & M06-2X/aug-cc-pVDZ & 142 \\
\hline $\mathrm{Cl}^{-}$ & 1,4-cyclohex & 48.09 & M06-2X/aug-cc-pVDZ & 142 \\
\hline $\mathrm{Cl}^{-}$ & $\mathrm{GeF}_{3} \mathrm{CN}$ & $46.32^{\mathrm{b}}$ & MP2/aug-cc-pVDZ & 46 \\
\hline $\mathrm{Cl}^{-}$ & meta & 45.03 & M06-2X/aug-cc-pVDZ & 142 \\
\hline $\mathrm{Cl}^{-}$ & para & 43.37 & M06-2X/aug-cc-pVDZ & 142 \\
\hline $\mathrm{Cl}^{-}$ & $\mathrm{GeF}_{4}$ & $41.26^{\mathrm{b}}$ & MP2/aug-cc-pVDZ & 46 \\
\hline $\mathrm{Cl}^{-}$ & meta-Me & 40.72 & M06-2X/aug-cc-pVDZ & 142 \\
\hline $\mathrm{Cl}^{-}$ & meta $\mathrm{C} \equiv \mathrm{C}$ & 40.28 & M06-2X/aug-cc-pVDZ & 142 \\
\hline $\mathrm{Cl}^{-}$ & $\mathrm{mono}^{\mathrm{c}}$ & 39.06 & M06-2X/aug-cc-pVDZ & 142 \\
\hline $\mathrm{Cl}^{-}$ & $\mathrm{Im}_{-\mathrm{SnH}_{3}}{ }^{+}$ & 38.08 & M06-2X/aug-cc-pVDZ & 137 \\
\hline $\mathrm{Cl}^{-}$ & $\mathrm{SiF}_{3} \mathrm{CN}$ & $37.29^{\mathrm{b}}$ & MP2/aug-cc-pVDZ & 46 \\
\hline $\mathrm{Cl}^{-}$ & $\mathrm{SiF}_{3} \mathrm{CN}$ & $37.29^{\mathrm{b}}$ & MP2/aug-cc-pVTZ & 45 \\
\hline $\mathrm{Cl}^{-}$ & Ge-receptor & 35.20 & M06-2X/aug-cc-pVDZ & 135 \\
\hline $\mathrm{Cl}^{-}$ & $\mathrm{PbMe}_{3} \mathrm{CN}$ & 32.4 & PBE0-D3/def2-TZVPD & 50 \\
\hline $\mathrm{Cl}^{-}$ & $\mathrm{Im}_{\mathrm{I}} \mathrm{I}^{+}$ & 28.38 & M06-2X/aug-cc-pVDZ & 137 \\
\hline $\mathrm{Cl}^{-}$ & $\mathrm{PbMe}_{3} \mathrm{~F}$ & 28.3 & PBE0-D3/def2-TZVPD & 50 \\
\hline
\end{tabular}




\begin{tabular}{|c|c|c|c|c|}
\hline $\mathrm{Cl}^{-}$ & $\mathrm{SnMe}_{3} \mathrm{~F}$ & $26.9^{\mathrm{b}}$ & PBE0-D3/def2-TZVPD & 50 \\
\hline $\mathrm{Cl}^{-}$ & $\mathrm{PbMe}_{3} \mathrm{CF}_{3}$ & 25.9 & PBE0-D3/def2-TZVPD & 50 \\
\hline $\mathrm{Cl}^{-}$ & $\mathrm{Im}^{\mathrm{Im}} \mathrm{H}^{+}$ & 25.08 & M06-2X/aug-cc-pVDZ & 137 \\
\hline $\mathrm{Cl}^{-}$ & $\mathrm{SiF}_{4}$ & $25.00^{\mathrm{b}}$ & MP2/aug-cc-pVDZ & 46 \\
\hline $\mathrm{Cl}^{-}$ & $\mathrm{SiF}_{4}$ & $25.00^{\mathrm{b}}$ & MP2/aug-cc-pVTZ & 45 \\
\hline $\mathrm{Cl}^{-}$ & $\mathrm{ImSnF}_{3}$ & 23.47 & M06-2X/aug-cc-pVDZ & 143 \\
\hline $\mathrm{Cl}^{-}$ & $\mathrm{ImPbF}_{3}$ & 20.62 & M06-2X/aug-cc-pVDZ & 143 \\
\hline $\mathrm{Cl}^{-}$ & Sn-receptor & 13.79 & M06-2X/aug-cc-pVDZ & 138 \\
\hline $\mathrm{Cl}^{-}$ & $\mathrm{CClH}_{3}$ & 11 & MP2/aug'-cc-pVTZ & 10 \\
\hline $\mathrm{Cl}^{-}$ & Ge-receptor & 9.32 & M06-2X/aug-cc-pVDZ & 138 \\
\hline $\mathrm{Cl}^{-}$ & $\mathrm{ImGeF}_{3}$ & 8.81 & M06-2X/aug-cc-pVDZ & 143 \\
\hline $\mathrm{Cl}^{-}$ & $\mathrm{PbMe}_{3} \mathrm{CH}_{3}$ & 7.7 & PBE0-D3/def2-TZVPD & 50 \\
\hline $\mathrm{Cl}^{-}$ & $\mathrm{CF}_{3} \mathrm{CN}$ & $5.51^{\mathrm{b}}$ & MP2/aug-cc-pVTZ & 45 \\
\hline $\mathrm{Cl}^{-}$ & $\mathrm{CClF}_{3}$ & 4 & MP2/aug'-cc-pVTZ & 10 \\
\hline $\mathrm{Cl}^{-}$ & $\mathrm{ImSnH}_{3}$ & 3.57 & M06-2X/aug-cc-pVDZ & 143 \\
\hline $\mathrm{Cl}^{-}$ & $\mathrm{CF}_{4}$ & $3.20^{\mathrm{b}}$ & MP2/aug-cc-pVTZ & 45 \\
\hline $\mathrm{Cl}^{-}$ & $\mathrm{ImPbH}_{3}$ & 2.78 & M06-2X/aug-cc-pVDZ & 143 \\
\hline $\mathrm{Cl}^{-}$ & $\mathrm{ImSiF}_{3}$ & 2.73 & M06-2X/aug-cc-pVDZ & 143 \\
\hline $\mathrm{Cl}^{-}$ & $\mathrm{ImGeH}_{3}$ & 1.87 & M06-2X/aug-cc-pVDZ & 143 \\
\hline $\mathrm{Cl}^{-}$ & $\mathrm{ImSiH}_{3}$ & 1.79 & M06-2X/aug-cc-pVDZ & 143 \\
\hline $\mathrm{Br}^{-}$ & FADXIR $^{\mathrm{a}}$ & 81.09 & M06-2X/aug-cc-pVDZ & 48 \\
\hline $\mathrm{Br}^{-}$ & POSTUM02 ${ }^{\mathrm{a}}$ & 79.82 & M06-2X/aug-cc-pVDZ & 48 \\
\hline $\mathrm{Br}^{-}$ & $\mathrm{LILLOH}^{\mathrm{a}}$ & 78.67 & M06-2X/aug-cc-pVDZ & 48 \\
\hline $\mathrm{Br}^{-}$ & $\mathrm{SiO}_{2}$ & 78.06 & CCSD/aug-cc-pVTZ & 47 \\
\hline $\mathrm{Br}^{-}$ & ZZZGVM01 $^{\mathrm{a}}$ & 77.97 & M06-2X/aug-cc-pVDZ & 48 \\
\hline $\mathrm{Br}^{-}$ & ZZZUQO03 $^{\mathrm{a}}$ & 76.63 & M06-2X/aug-cc-pVDZ & 48 \\
\hline $\mathrm{Br}^{-}$ & $\mathrm{GeO}_{2}$ & 65.37 & CCSD/aug-cc-pVTZ & 47 \\
\hline $\mathrm{Br}^{-}$ & calix[4]pyrrol & 64.9 & BP86-D3/def2-TZVP & 144 \\
\hline $\mathrm{Br}^{-}$ & octamethyl calix[4]pyrrol derivative & 60.2 & BP86-D3/def2-TZVP & 144 \\
\hline $\mathrm{Br}^{-}$ & tetramethyl calix[4]pyrrol derivative & 58.2 & BP86-D3/def2-TZVP & 144 \\
\hline $\mathrm{Br}^{-}$ & $\mathrm{SnF}_{3} \mathrm{CN}$ & $56.59^{\mathrm{b}}$ & MP2/aug-cc-pVDZ & 46 \\
\hline $\mathrm{Br}^{-}$ & $\mathrm{SnF}_{4}$ & $54.44^{\mathrm{b}}$ & MP2/aug-cc-pVDZ & 46 \\
\hline $\mathrm{Br}^{-}$ & $\mathrm{GeF}_{3} \mathrm{CN}$ & $37.73^{\mathrm{b}}$ & MP2/aug-cc-pVDZ & 46 \\
\hline $\mathrm{Br}^{-}$ & $\mathrm{GeF}_{4}$ & $32.99^{\mathrm{b}}$ & MP2/aug-cc-pVDZ & 46 \\
\hline $\mathrm{Br}^{-}$ & Ge-receptor & 29.95 & M06-2X/aug-cc-pVDZ & 135 \\
\hline $\mathrm{Br}^{-}$ & $\mathrm{PbMe}_{3} \mathrm{CN}$ & $28.0^{\mathrm{b}}$ & PBE0-D3/def2-TZVPD & 50 \\
\hline $\mathrm{Br}^{-}$ & $\mathrm{SiF}_{3} \mathrm{CN}$ & $27.60^{\mathrm{b}}$ & MP2/aug-cc-pVDZ & 46 \\
\hline $\mathrm{Br}^{-}$ & $\mathrm{SiF}_{3} \mathrm{CN}$ & $27.60^{\mathrm{b}}$ & MP2/aug-cc-pVTZ & 45 \\
\hline $\mathrm{Br}^{-}$ & $\mathrm{PbMe}_{3} \mathrm{~F}$ & $23.9^{\mathrm{b}}$ & PBE0-D3/def2-TZVPD & 50 \\
\hline $\mathrm{Br}^{-}$ & $\mathrm{PbMe}_{3} \mathrm{CF}_{3}$ & $21.6^{\mathrm{b}}$ & PBE0-D3/def2-TZVPD & 50 \\
\hline
\end{tabular}




\begin{tabular}{|c|c|c|c|c|}
\hline $\mathrm{Br}^{-}$ & $\mathrm{SnMe}_{3} \mathrm{~F}$ & $21.3^{\mathrm{b}}$ & PBE0-D3/def2-TZVPD & 50 \\
\hline $\mathrm{Br}^{-}$ & $\mathrm{SiF}_{4}$ & $16.35^{\mathrm{b}}$ & MP2/aug-cc-pVDZ & 46 \\
\hline $\mathrm{Br}^{-}$ & $\mathrm{SiF}_{4}$ & $16.35^{\mathrm{b}}$ & MP2/aug-cc-pVTZ & 45 \\
\hline $\mathrm{Br}^{-}$ & Sn-receptor & 11.87 & M06-2X/aug-cc-pVDZ & 138 \\
\hline $\mathrm{Br}^{-}$ & Ge-receptor & 8.55 & M06-2X/aug-cc-pVDZ & 138 \\
\hline $\mathrm{Br}^{-}$ & $\mathrm{CO}_{2}$ & 5.60 & CCSD/aug-cc-pVTZ & 47 \\
\hline $\mathrm{Br}^{-}$ & $\mathrm{CF}_{3} \mathrm{CN}$ & $4.83^{\mathrm{b}}$ & MP2/aug-cc-pVTZ & 45 \\
\hline $\mathrm{Br}^{-}$ & $\mathrm{PbMe}_{3} \mathrm{CH}_{3}$ & $3.4^{\mathrm{b}}$ & PBE0-D3/def2-TZVPD & 50 \\
\hline $\mathrm{Br}^{-}$ & $\mathrm{CF}_{4}$ & $2.67^{\mathrm{b}}$ & MP2/aug-cc-pVTZ & 45 \\
\hline $\mathrm{I}^{-}$ & calix[4]pyrrol & 56.5 & BP86-D3/def2-TZVP & 144 \\
\hline $\mathrm{I}^{-}$ & octamethyl calix[4]pyrrol derivative & 52.2 & BP86-D3/def2-TZVP & 144 \\
\hline $\mathrm{I}^{-}$ & tetramethyl calix[4]pyrrol derivative & 51.3 & BP86-D3/def2-TZVP & 144 \\
\hline $\mathrm{I}^{-}$ & $\mathrm{PbMe}_{3} \mathrm{CN}$ & $24.6^{\mathrm{b}}$ & PBE0-D3/def2-TZVPD & 50 \\
\hline $\mathrm{I}^{-}$ & Ge-receptor & 24.46 & M06-2X/aug-cc-pVDZ & 135 \\
\hline $\mathrm{I}^{-}$ & $\mathrm{PbMe}_{3} \mathrm{~F}$ & $19.7^{\mathrm{b}}$ & PBE0-D3/def2-TZVPD & 50 \\
\hline $\mathrm{I}^{-}$ & $\mathrm{PbMe}_{3} \mathrm{CF}_{3}$ & $17.6^{\mathrm{b}}$ & PBE0-D3/def2-TZVPD & 50 \\
\hline $\mathrm{I}^{-}$ & $\mathrm{SnMe}_{3} \mathrm{~F}$ & $15.9^{\mathrm{b}}$ & PBE0-D3/def2-TZVPD & 50 \\
\hline $\mathrm{I}^{-}$ & $\mathrm{PbMe}_{3} \mathrm{CH}_{3}$ & $2.7^{\mathrm{b}}$ & PBE0-D3/def2-TZVPD & 50 \\
\hline
\end{tabular}

a ligands with $\mathrm{CH}_{3} \mathrm{Y}(\mathrm{Y}=\mathrm{N}, \mathrm{O})$ motifs taken form CSD

${ }^{b}$ interaction energy 
Table 3 Calculated binding energies between polyatomic anion and a single ligand in tetrel bonded clusters.

\begin{tabular}{|c|c|c|c|c|}
\hline anion & ligand & $\begin{array}{c}-\mathrm{E}_{\mathrm{b}} \\
\mathrm{kcal} / \mathrm{mol}\end{array}$ & level of theory & reference \\
\hline $\mathrm{NCS}^{-}$ & $\mathrm{SiF}_{3} \mathrm{CN}$ & $37.38^{b}$ & MP2/aug-cc-pVTZ & 45 \\
\hline $\mathrm{NCS}^{-}$ & $\mathrm{SiF}_{4}$ & $26.59^{b}$ & MP2/aug-cc-pVTZ & 45 \\
\hline $\mathrm{SCN}^{-}$ & $\mathrm{SiF}_{3} \mathrm{CN}$ & $22.10^{\mathrm{b}}$ & MP2/aug-cc-pVTZ & 45 \\
\hline $\mathrm{SCN}^{-}$ & $\mathrm{SiF}_{4}$ & $12.53^{\mathrm{b}}$ & MP2/aug-cc-pVTZ & 45 \\
\hline $\mathrm{NCS}^{-}$ & $\mathrm{CF}_{3} \mathrm{CN}$ & $4.93^{\mathrm{b}}$ & MP2/aug-cc-pVTZ & 45 \\
\hline $\mathrm{SCN}^{-}$ & $\mathrm{CF}_{3} \mathrm{CN}$ & $3.48^{\mathrm{b}}$ & MP2/aug-cc-pVTZ & 45 \\
\hline $\mathrm{NCS}^{-}$ & $\mathrm{CF}_{4}$ & $3.08^{\mathrm{b}}$ & MP2/aug-cc-pVTZ & 45 \\
\hline $\mathrm{SCN}^{-}$ & $\mathrm{CF}_{4}$ & $1.74^{\mathrm{b}}$ & MP2/aug-cc-pVTZ & 45 \\
\hline $\mathrm{CN}^{-}$ & $\mathrm{SnF}_{3} \mathrm{CN}$ & $72.26^{\mathrm{b}}$ & MP2/aug-cc-pVDZ & 46 \\
\hline $\mathrm{CN}^{-}$ & $\mathrm{SnF}_{4}$ & $70.26^{\mathrm{b}}$ & MP2/aug-cc-pVDZ & 46 \\
\hline $\mathrm{NC}^{-}$ & $\mathrm{SnF}_{3} \mathrm{CN}$ & $64.21^{\mathrm{b}}$ & MP2/aug-cc-pVDZ & 46 \\
\hline $\mathrm{NC}^{-}$ & $\mathrm{SnF}_{4}$ & $62.50^{\mathrm{b}}$ & MP2/aug-cc-pVDZ & 46 \\
\hline $\mathrm{CN}^{-}$ & $\mathrm{GeF}_{3} \mathrm{CN}$ & $58.35^{\mathrm{b}}$ & MP2/aug-cc-pVDZ & 46 \\
\hline $\mathrm{CN}^{-}$ & $\mathrm{GeF}_{4}$ & $53.57^{\mathrm{b}}$ & MP2/aug-cc-pVDZ & 46 \\
\hline $\mathrm{NC}^{-}$ & $\mathrm{GeF}_{3} \mathrm{CN}$ & $50.96^{\mathrm{b}}$ & MP2/aug-cc-pVDZ & 46 \\
\hline $\mathrm{CN}^{-}$ & $\mathrm{SiF}_{3} \mathrm{CN}$ & $50.72^{\mathrm{b}}$ & MP2/aug-cc-pVDZ & 46 \\
\hline $\mathrm{CN}^{-}$ & $\mathrm{SiF}_{3} \mathrm{CN}$ & $50.72^{\mathrm{b}}$ & MP2/aug-cc-pVTZ & 45 \\
\hline $\mathrm{NC}^{-}$ & $\mathrm{GeF}_{4}$ & $46.62^{b}$ & MP2/aug-cc-pVDZ & 46 \\
\hline $\mathrm{NC}^{-}$ & $\mathrm{SiF}_{3} \mathrm{CN}$ & $46.59^{b}$ & MP2/aug-cc-pVDZ & 46 \\
\hline $\mathrm{NC}^{-}$ & $\mathrm{SiF}_{3} \mathrm{CN}$ & $46.59^{\mathrm{b}}$ & MP2/aug-cc-pVTZ & 45 \\
\hline $\mathrm{CN}^{-}$ & $\mathrm{SiF}_{4}$ & $38.86^{\mathrm{b}}$ & MP2/aug-cc-pVDZ & 46 \\
\hline $\mathrm{CN}^{-}$ & $\mathrm{SiF}_{4}$ & $38.86^{\mathrm{b}}$ & MP2/aug-cc-pVTZ & 45 \\
\hline $\mathrm{NC}^{-}$ & $\mathrm{SiF}_{4}$ & $35.03^{\mathrm{b}}$ & MP2/aug-cc-pVDZ & 46 \\
\hline $\mathrm{NC}^{-}$ & $\mathrm{SiF}_{4}$ & $35.03^{\mathrm{b}}$ & MP2/aug-cc-pVTZ & 45 \\
\hline $\mathrm{NC}^{-}$ & $\mathrm{CO}_{2}$ & 8.34 & CCSD/aug-cc-pVTZ & 47 \\
\hline $\mathrm{CN}^{-}$ & $\mathrm{CO}_{2}$ & 8.25 & CCSD/aug-cc-pVTZ & 47 \\
\hline $\mathrm{NC}^{-}$ & $\mathrm{CF}_{3} \mathrm{CN}$ & $5.68^{\mathrm{b}}$ & MP2/aug-cc-pVTZ & 45 \\
\hline $\mathrm{CN}^{-}$ & $\mathrm{CF}_{3} \mathrm{CN}$ & $5.00^{\mathrm{b}}$ & MP2/aug-cc-pVTZ & 45 \\
\hline $\mathrm{NC}^{-}$ & $\mathrm{CF}_{4}$ & $3.54^{\mathrm{b}}$ & MP2/aug-cc-pVTZ & 45 \\
\hline $\mathrm{CN}^{-}$ & $\mathrm{CF}_{4}$ & $2.93^{\mathrm{b}}$ & MP2/aug-cc-pVTZ & 45 \\
\hline $\mathrm{N}_{3}^{-}$ & calix[4]pyrrol & 69.5 & BP86-D3/def2-TZVP & 144 \\
\hline $\mathrm{N}_{3}^{-}$ & $\begin{array}{c}\text { octamethyl } \\
\text { calix[4]pyrrol } \\
\text { derivative }\end{array}$ & 63.0 & BP86-D3/def2-TZVP & 144 \\
\hline $\mathrm{N}_{3}^{-}$ & $\mathrm{SnF}_{3} \mathrm{CN}$ & $62.09^{b}$ & MP2/aug-cc-pVDZ & 46 \\
\hline $\mathrm{N}_{3}^{-}$ & $\mathrm{SnF}_{4}$ & $60.07^{\mathrm{b}}$ & MP2/aug-cc-pVDZ & 46 \\
\hline
\end{tabular}




\begin{tabular}{|c|c|c|c|c|}
\hline $\mathrm{N}_{3}^{-}$ & $\begin{array}{c}\text { tetramethyl } \\
\text { calix[4]pyrrol } \\
\text { derivative }\end{array}$ & 59.9 & BP86-D3/def2-TZVP & 144 \\
\hline $\mathrm{N}_{3}^{-}$ & $\mathrm{GeF}_{3} \mathrm{CN}$ & $47.94^{\mathrm{b}}$ & MP2/aug-cc-pVDZ & 46 \\
\hline $\mathrm{N}_{3}^{-}$ & $\mathrm{GeF}_{4}$ & $43.30^{\mathrm{b}}$ & MP2/aug-cc-pVDZ & 46 \\
\hline $\mathrm{N}_{3}^{-}$ & $\mathrm{SiF}_{3} \mathrm{CN}$ & $42.68^{\mathrm{b}}$ & MP2/aug-cc-pVTZ & 45 \\
\hline $\mathrm{N}_{3}^{-}$ & $S-\mathrm{SnH}_{3} \mathrm{~F}$ & $42.49^{\mathrm{b}}$ & MP2/aug-cc-pVTZ & 43 \\
\hline $\mathrm{N}_{3}^{-}$ & $\mathrm{SiF}_{3} \mathrm{CN}$ & $41.87^{\mathrm{b}}$ & MP2/aug-cc-pVDZ & 46 \\
\hline $\mathrm{N}_{3}^{-}$ & $\mathrm{SiH}_{3} \mathrm{~F}$ & 40.91 & CCSD/aug-cc-pVTZ & 47 \\
\hline $\mathrm{N}_{3}^{-}$ & $S-\mathrm{SiH}_{3} \mathrm{~F}$ & $37.17^{\mathrm{b}}$ & MP2/aug-cc-pVTZ & 43 \\
\hline $\mathrm{N}_{3}^{-}$ & $\mathrm{GeH}_{3} \mathrm{~F}$ & 36.72 & CCSD/aug-cc-pVTZ & 47 \\
\hline $\mathrm{N}_{3}^{-}$ & $S-\mathrm{GeH}_{3} \mathrm{~F}$ & $34.41^{\mathrm{b}}$ & MP2/aug-cc-pVTZ & 43 \\
\hline $\mathrm{N}_{3}^{-}$ & $\mathrm{SiF}_{4}$ & $30.89^{b}$ & MP2/aug-cc-pVTZ & 45 \\
\hline $\mathrm{N}_{3}^{-}$ & $\mathrm{SiF}_{4}$ & $30.08^{b}$ & MP2/aug-cc-pVDZ & 46 \\
\hline $\mathrm{N}_{3}^{-}$ & $\mathrm{CH}_{3} \mathrm{~F}$ & 9.21 & CCSD/aug-cc-pVTZ & 47 \\
\hline $\mathrm{N}_{3}^{-}$ & $L-\mathrm{CH}_{3} \mathrm{~F}$ & $8.98^{\mathrm{b}}$ & MP2/aug-cc-pVTZ & 43 \\
\hline $\mathrm{N}_{3}^{-}$ & $\mathrm{CO}_{2}$ & 6.79 & CCSD/aug-cc-pVTZ & 47 \\
\hline $\mathrm{N}_{3}^{-}$ & $\mathrm{CF}_{3} \mathrm{CN}$ & $6.32^{\mathrm{b}}$ & MP2/aug-cc-pVTZ & 45 \\
\hline $\mathrm{N}_{3}^{-}$ & $\mathrm{CF}_{4}$ & $4.25^{\mathrm{b}}$ & MP2/aug-cc-pVTZ & 45 \\
\hline $\mathrm{HCO}_{2}^{-}$ & ortho $\mathrm{C} \equiv \mathrm{C}^{\mathrm{c}}$ & 66.38 & M06-2X/aug-cc-pVDZ & 142 \\
\hline $\mathrm{HCO}_{2}^{-}$ & ortho di $\mathrm{C} \equiv \mathrm{C}^{\mathrm{c}}$ & 65.74 & M06-2X/aug-cc-pVDZ & 142 \\
\hline $\mathrm{HCO}_{2}^{-}$ & ortho $^{c}$ & 59.00 & M06-2X/aug-cc-pVDZ & 142 \\
\hline $\mathrm{HCO}_{2}^{-}$ & 1,3 -cyclohex ${ }^{c}$ & 57.23 & M06-2X/aug-cc-pVDZ & 142 \\
\hline $\mathrm{HCO}_{2}^{-}$ & $1,4-$ cyclohex $^{\mathrm{c}}$ & 56.32 & M06-2X/aug-cc-pVDZ & 142 \\
\hline $\mathrm{HCO}_{2}^{-}$ & octocycle $^{\mathrm{c}}$ & 54.91 & M06-2X/aug-cc-pVDZ & 142 \\
\hline $\mathrm{HCO}_{2}^{-}$ & meta $^{\mathrm{c}}$ & 51.18 & M06-2X/aug-cc-pVDZ & 142 \\
\hline $\mathrm{HCO}_{2}^{-}$ & para $^{\mathrm{c}}$ & 48.74 & M06-2X/aug-cc-pVDZ & 142 \\
\hline $\mathrm{HCO}_{2}^{-}$ & meta $\mathrm{C} \equiv \mathrm{C}^{\mathrm{c}}$ & 45.76 & M06-2X/aug-cc-pVDZ & 142 \\
\hline $\mathrm{HCO}_{2}^{-}$ & meta-Me $\mathrm{c}^{\mathrm{c}}$ & 45.19 & M06-2X/aug-cc-pVDZ & 142 \\
\hline $\mathrm{HCO}_{2}^{-}$ & mono $^{\mathrm{c}}$ & 43.24 & M06-2X/aug-cc-pVDZ & 142 \\
\hline $\mathrm{HSO}_{4}^{-}$ & ortho di $\mathrm{C} \equiv \mathrm{C}^{\mathrm{c}}$ & 51.58 & M06-2X/aug-cc-pVDZ & 142 \\
\hline $\mathrm{HSO}_{4}^{-}$ & ortho $\mathrm{C} \equiv \mathrm{C}^{\mathrm{c}}$ & 45.37 & M06-2X/aug-cc-pVDZ & 142 \\
\hline $\mathrm{HSO}_{4}^{-}$ & 1,4-cyclohex ${ }^{\mathrm{c}}$ & 41.32 & M06-2X/aug-cc-pVDZ & 142 \\
\hline $\mathrm{HSO}_{4}^{-}$ & meta $^{\mathrm{c}}$ & 39.37 & M06-2X/aug-cc-pVDZ & 142 \\
\hline $\mathrm{HSO}_{4}^{-}$ & ortho $^{c}$ & 39.12 & M06-2X/aug-cc-pVDZ & 142 \\
\hline $\mathrm{HSO}_{4}^{-}$ & 1,3 -cyclohex ${ }^{\mathrm{c}}$ & 38.98 & M06-2X/aug-cc-pVDZ & 142 \\
\hline $\mathrm{HSO}_{4}^{-}$ & octocycle $^{c}$ & 37.58 & M06-2X/aug-cc-pVDZ & 142 \\
\hline $\mathrm{HSO}_{4}^{-}$ & meta-Me $\mathrm{c}^{\mathrm{c}}$ & 34.17 & M06-2X/aug-cc-pVDZ & 142 \\
\hline $\mathrm{HSO}_{4}^{-}$ & para $^{\mathrm{c}}$ & 33.49 & M06-2X/aug-cc-pVDZ & 142 \\
\hline $\mathrm{HSO}_{4}^{-}$ & meta $\mathrm{C} \equiv \mathrm{C}^{\mathrm{c}}$ & 31.99 & M06-2X/aug-cc-pVDZ & 142 \\
\hline $\mathrm{HSO}_{4}^{-}$ & Mono $^{\mathrm{c}}$ & 29.12 & M06-2X/aug-cc-pVDZ & 142 \\
\hline
\end{tabular}




\begin{tabular}{|c|c|c|c|c|}
\hline $\mathrm{H}_{2} \mathrm{PO}_{4}^{-}$ & ortho $\mathrm{C} \equiv \mathrm{C}^{\mathrm{c}}$ & 64.01 & M06-2X/aug-cc-pVDZ & 142 \\
\hline $\mathrm{H}_{2} \mathrm{PO}_{4}^{-}$ & ortho di $\mathrm{C} \equiv \mathrm{C}^{\mathrm{c}}$ & 58.65 & M06-2X/aug-cc-pVDZ & 142 \\
\hline $\mathrm{H}_{2} \mathrm{PO}_{4}^{-}$ & ortho $^{c}$ & 53.18 & M06-2X/aug-cc-pVDZ & 142 \\
\hline $\mathrm{H}_{2} \mathrm{PO}_{4}^{-}$ & $1,4-$ cyclohex $^{\mathrm{c}}$ & 52.76 & M06-2X/aug-cc-pVDZ & 142 \\
\hline $\mathrm{H}_{2} \mathrm{PO}_{4}^{-}$ & meta $^{\mathrm{c}}$ & 50.87 & M06-2X/aug-cc-pVDZ & 142 \\
\hline $\mathrm{H}_{2} \mathrm{PO}_{4}^{-}$ & $1,3-$ cyclohex $^{\mathrm{c}}$ & 50.83 & M06-2X/aug-cc-pVDZ & 142 \\
\hline $\mathrm{H}_{2} \mathrm{PO}_{4}^{-}$ & meta-Me $^{\mathrm{c}}$ & 48.19 & M06-2X/aug-cc-pVDZ & 142 \\
\hline $\mathrm{H}_{2} \mathrm{PO}_{4}^{-}$ & octocycle $^{\mathrm{c}}$ & 46.93 & M06-2X/aug-cc-pVDZ & 142 \\
\hline $\mathrm{H}_{2} \mathrm{PO}_{4}^{-}$ & meta $\mathrm{C} \equiv \mathrm{C}^{\mathrm{c}}$ & 42.48 & M06-2X/aug-cc-pVDZ & 142 \\
\hline $\mathrm{H}_{2} \mathrm{PO}_{4}^{-}$ & para $^{\mathrm{c}}$ & 39.26 & M06-2X/aug-cc-pVDZ & 142 \\
\hline $\mathrm{H}_{2} \mathrm{PO}_{4}^{-}$ & mono $^{\mathrm{c}}$ & 35.43 & M06-2X/aug-cc-pVDZ & 142 \\
\hline $\mathrm{NCO}^{-}$ & calix[4]pyrrol & 57.6 & BP86-D3/def2-TZVP & 144 \\
\hline $\mathrm{NCO}^{-}$ & $\begin{array}{c}\text { octamethyl } \\
\text { calix[4]pyrrol } \\
\text { derivative }\end{array}$ & 56.2 & BP86-D3/def2-TZVP & 144 \\
\hline $\mathrm{NCO}^{-}$ & $\begin{array}{c}\text { tetramethyl } \\
\text { calix[4]pyrrol } \\
\text { derivative }\end{array}$ & 53.1 & BP86-D3/def2-TZVP & 144 \\
\hline $\mathrm{NCO}^{-}$ & $\mathrm{CH}_{3} \mathrm{~F}$ & 9.89 & CCSD/aug-cc-pVTZ & 47 \\
\hline $\mathrm{OCN}^{-}$ & $\mathrm{CH}_{3} \mathrm{~F}$ & 8.37 & CCSD/aug-cc-pVTZ & 47 \\
\hline $\mathrm{PhO}^{-}$ & perfluorotoluene & $76.3^{\mathrm{b}}$ & MP2/def2-TZVP & 44 \\
\hline $\mathrm{PhO}^{-}$ & perfluorotoluene & $8.9^{\mathrm{b}}$ & MP2/def2-TZVP & 44 \\
\hline $\mathrm{HCOO}^{-}$ & perfluorotoluene & $11.6^{\mathrm{b}}$ & MP2/def2-TZVP & 44 \\
\hline $\mathrm{HCOO}^{-}$ & perfluorotoluene & $91.2^{\mathrm{b}}$ & MP2/def2-TZVP & 44 \\
\hline $\mathrm{SH}^{-}$ & $\mathrm{CO}_{2}$ & 3.99 & CCSD/aug-cc-pVTZ & 47 \\
\hline
\end{tabular}
a ligands with $\mathrm{CH}_{3} \mathrm{Y}(\mathrm{Y}=\mathrm{N}, \mathrm{O})$ motifs taken from CSD
$\mathrm{b}$ interaction energy
${ }^{c}$ the names concern the position of $\mathrm{SnFH}_{2}$ substitution position on phenyl ring 
Table 4 Calculated binding energies between anion and a single ligand in pnicogen bonded clusters.

\begin{tabular}{|c|c|c|c|c|}
\hline anion & ligand & $\begin{array}{c}-\mathrm{E}_{\mathrm{b}}, \\
\mathrm{kcal} / \mathrm{mol}\end{array}$ & level of theory & reference \\
\hline \multicolumn{5}{|c|}{ monoatomic anion } \\
\hline $\mathrm{F}^{-}$ & $\mathrm{FH}_{2} \mathrm{As}$ & 46.08 & MP2/aug-cc-pVTZ & 67 \\
\hline $\mathrm{F}^{-}$ & $\mathrm{FH}_{2} \mathrm{P}$ & 41.94 & MP2/aug-cc-pVTZ & 67 \\
\hline $\mathrm{F}^{-}$ & $\mathrm{CF}_{3} \mathrm{NO}_{2}$ & $27.1^{\mathrm{a}}$ & BP86-D3/def2-TZVP & 53 \\
\hline $\mathrm{F}^{-}$ & $\mathrm{CH}_{3} \mathrm{NO}_{2}$ & $11.5^{\mathrm{a}}$ & BP86-D3/def2-TZVP & 53 \\
\hline $\mathrm{Cl}^{-}$ & spiro-[2.2]pentane cation with As (A) & 183.3 & MP2/6-311++G(d,p) & 145 \\
\hline $\mathrm{Cl}^{-}$ & spiro-[2.2]pentane cation with $\mathrm{P}(\mathrm{A})$ & 165.7 & MP2/6-311++G(d,p) & 145 \\
\hline $\mathrm{Cl}^{-}$ & spiro-[2.2]pentane cation with $\mathrm{N}(\mathrm{A})$ & 144.2 & MP2/6-311++G(d,p) & 145 \\
\hline $\mathrm{Cl}^{-}$ & spiro-[2.2]pentane cation with As (B) & 119.4 & MP2/6-311++G(d,p) & 145 \\
\hline $\mathrm{Cl}^{-}$ & spiro-[2.2]pentane cation with $\mathrm{P}(\mathrm{B})$ & 116.2 & MP2/6-311++G(d,p) & 145 \\
\hline $\mathrm{Cl}^{-}$ & spiro-[2.2]pentane cation with As (C) & 112.8 & MP2/6-311++G(d,p) & 145 \\
\hline $\mathrm{Cl}^{-}$ & spiro-[2.2]pentane cation with $\mathrm{P}(\mathrm{C})$ & 111.5 & MP2/6-311++G(d,p) & 145 \\
\hline $\mathrm{Cl}^{-}$ & spiro-[2.2]pentane cation with $\mathrm{N}(\mathrm{B})$ & 99.8 & MP2/6-311++G(d,p) & 145 \\
\hline $\mathrm{Cl}^{-}$ & spiro-[2.2]pentane cation with $\mathrm{N}(\mathrm{C})$ & 96.3 & MP2/6-311++G(d,p) & 145 \\
\hline $\mathrm{Cl}^{-}$ & spiro-[2.2]pentane cation with As (D) & 91.7 & MP2/6-311++G(d,p) & 145 \\
\hline $\mathrm{Cl}^{-}$ & spiro-[2.2]pentane cation with $\mathrm{N}$ (D) & 85.9 & MP2/6-311++G(d,p) & 145 \\
\hline $\mathrm{Cl}^{-}$ & spiro-[2.2]pentane cation with $\mathrm{P}(\mathrm{D})$ & 85.6 & MP2/6-311++G(d,p) & 145 \\
\hline $\mathrm{Cl}^{-}$ & $\mathrm{As}_{3} \mathrm{Cl}$ & $53.5^{\mathrm{a}}$ & CCSD(T)/aug-cc-pVTZ & 26 \\
\hline $\mathrm{Cl}^{-}$ & $\mathrm{PO}_{2}^{\cdot-} \pi$-hole & $47.3^{\mathrm{a}}$ & RI-MP2/aug-ccpVQZ & 42 \\
\hline $\mathrm{Cl}^{-}$ & $\mathrm{PO}_{2}^{\cdot-} \sigma$-hole & $35.3^{\mathrm{a}}$ & RI-MP2/aug-ccpVQZ & 42 \\
\hline $\mathrm{Cl}^{-}$ & $\mathrm{FH}_{2} \mathrm{As}$ & 25.01 & MP2/aug-cc-pVTZ & 67 \\
\hline $\mathrm{Cl}^{-}$ & $\mathrm{FH}_{2} \mathrm{P}$ & 19.80 & MP2/aug-cc-pVTZ & 67 \\
\hline $\mathrm{Cl}^{-}$ & 4-nitrobenzonitrile & $15.0^{\mathrm{a}}$ & RI-MP2/def2-TZVPD & 54 \\
\hline $\mathrm{Cl}^{-}$ & $\mathrm{CF}_{3} \mathrm{NO}_{2}$ & $12.2^{\mathrm{a}}$ & BP86-D3/def2-TZVP & 53 \\
\hline $\mathrm{Cl}^{-}$ & 4-nitropyridine & $11.5^{\mathrm{a}}$ & RI-MP2/def2-TZVPD & 54 \\
\hline $\mathrm{Cl}^{-}$ & $\mathrm{CH}_{3} \mathrm{NO}_{2}$ & $6.7^{\mathrm{a}}$ & BP86-D3/def2-TZVP & 53 \\
\hline $\mathrm{Br}^{-}$ & $\mathrm{PO}_{2}{ }^{--} \pi$-hole & $41.1^{\mathrm{a}}$ & RI-MP2/aug-ccpVQZ & 42 \\
\hline $\mathrm{Br}^{-}$ & $\mathrm{PO}_{2}^{\cdot-} \sigma$-hole & $33.4^{\mathrm{a}}$ & RI-MP2/aug-ccpVQZ & 42 \\
\hline $\mathrm{Br}^{-}$ & $\mathrm{As}_{3} \mathrm{Cl}$ & $33.3^{\mathrm{a}}$ & CCSD(T)/aug-cc-pVTZ & 26 \\
\hline $\mathrm{Br}^{-}$ & $\mathrm{FH}_{2} \mathrm{As}$ & 21.59 & MP2/aug-cc-pVTZ & 67 \\
\hline $\mathrm{Br}^{-}$ & $\mathrm{FH}_{2} \mathrm{P}$ & 16.79 & MP2/aug-cc-pVTZ & 67 \\
\hline $\mathrm{Br}^{-}$ & 4-nitrobenzonitrile & $13.5^{\mathrm{a}}$ & RI-MP2/def2-TZVPD & 54 \\
\hline $\mathrm{Br}^{-}$ & $\mathrm{CF}_{3} \mathrm{NO}_{2}$ & $10.3^{\mathrm{a}}$ & BP86-D3/def2-TZVP & 53 \\
\hline $\mathrm{Br}^{-}$ & 4-nitropyridine & $10.2^{\mathrm{a}}$ & RI-MP2/def2-TZVPD & 54 \\
\hline $\mathrm{Br}^{-}$ & $\mathrm{CH}_{3} \mathrm{NO}_{2}$ & $5.9^{\mathrm{a}}$ & BP86-D3/def2-TZVP & 53 \\
\hline $\mathrm{I}^{-}$ & $\mathrm{FH}_{2} \mathrm{As}$ & 18.17 & MP2/aug-cc-pVTZ & 67 \\
\hline
\end{tabular}




\begin{tabular}{|c|c|c|c|c|}
\hline $\mathrm{I}^{-}$ & $\mathrm{FH}_{2} \mathrm{P}$ & 13.85 & MP2/aug-cc-pVTZ & 67 \\
\hline $\mathrm{I}^{-}$ & 4-nitrobenzonitrile & $12.7^{\mathrm{a}}$ & RI-MP2/def2-TZVPD & 54 \\
\hline $\mathrm{I}^{-}$ & 4-nitropyridine & $9.1^{\mathrm{a}}$ & RI-MP2/def2-TZVPD & 54 \\
\hline \multicolumn{5}{|c|}{ polyatomic anion } \\
\hline $\mathrm{NO}_{3}^{-}$ & $\mathrm{FH}_{2} \mathrm{As}$ & 22.60 & MP2/aug-cc-pVTZ & 67 \\
\hline $\mathrm{NO}_{3}^{-}$ & $\mathrm{FH}_{2} \mathrm{P}$ & 18.49 & MP2/aug-cc-pVTZ & 67 \\
\hline $\mathrm{NO}_{3}{ }^{-}$ & 4-nitrobenzonitrile & $15.4^{\mathrm{a}}$ & RI-MP2/def2-TZVPD & 54 \\
\hline $\mathrm{NO}_{3}^{-}$ & 4-nitropyridine & $11.8^{\mathrm{a}}$ & RI-MP2/def2-TZVPD & 54 \\
\hline $\mathrm{SO}_{4}^{2-}$ & $\mathrm{FH}_{2} \mathrm{As}$ & 49.61 & MP2/aug-cc-pVTZ & 67 \\
\hline $\mathrm{SO}_{4}^{2-}$ & $\mathrm{FH}_{2} \mathrm{P}$ & 43.20 & MP2/aug-cc-pVTZ & 67 \\
\hline $\mathrm{SCN}^{-}$ & $\mathrm{PO}_{2} \bullet-\pi$-hole & $38.0^{\mathrm{a}}$ & RI-MP2/aug-ccpVQZ & 42 \\
\hline $\mathrm{SCN}^{-}$ & $\mathrm{PO}_{2} \bullet-\sigma$-hole & $33.7^{\mathrm{a}}$ & RI-MP2/aug-ccpVQZ & 42 \\
\hline$\left(\mathrm{PH}_{2} \mathrm{~F}\right)_{2}{ }^{2-}$ & dimer & 28.69 & CCSD(T)/aug-cc-pVTZ & 146 \\
\hline$\left(\mathrm{PH}_{2} \mathrm{~F}\right)_{2}{ }^{-}$ & dimer & -30.39 & CCSD(T)/aug-cc-pVTZ & 146 \\
\hline
\end{tabular}

a interaction energy 
Table 5 Calculated binding energies between anion and a single ligand in chalcogen bonded clusters.

\begin{tabular}{|c|c|c|c|c|}
\hline anion & ligand & $\begin{array}{c}-\mathrm{E}_{\mathrm{b}} \\
\mathrm{kcal} / \mathrm{mol}\end{array}$ & level of theory & reference \\
\hline \multicolumn{5}{|c|}{ monoatomic anion } \\
\hline $\mathrm{F}^{-}$ & 3,4-dicyano-1,2,5-telluradiazole & 86.2 & B97-D3/def2-TZVP & 37 \\
\hline $\mathrm{F}^{-}$ & 3,4-dicyano-1,2,5-selenadiazole & 72.1 & B97-D3/def2-TZVP & 37 \\
\hline $\mathrm{F}^{-}$ & 3,4-dicyano-1,2,5-sulfuradiazole & 61.2 & B97-D3/def2-TZVP & 37 \\
\hline $\mathrm{F}^{-}$ & $\mathrm{Se}(\mathrm{CN})_{2}$ & 54.7 & MP2/aug-cc-pVTZ & 36 \\
\hline $\mathrm{F}^{-}$ & $\mathrm{S}(\mathrm{CN})_{2}$ & 46.8 & MP2/aug-cc-pVTZ & 36 \\
\hline $\mathrm{F}^{-}$ & $\mathrm{C}_{6} \mathrm{~F}_{4} \mathrm{O}_{2}$ & 32.6 & MP2/6-311++G(d,p) & 140 \\
\hline $\mathrm{F}^{-}$ & $\mathrm{SeCl}_{2}$ & 32.6 & MP2/aug-cc-pVTZ & 36 \\
\hline $\mathrm{F}^{-}$ & $\mathrm{C}_{6} \mathrm{~F}_{4}(\mathrm{CN})_{2}$ & 28.3 & MP2/6-311++G(d,p) & 140 \\
\hline $\mathrm{F}^{-}$ & $\mathrm{C}_{6} \mathrm{H}_{4} \mathrm{O}_{2}$ & 15.8 & $\mathrm{MP} 2 / 6-311++\mathrm{G}(\mathrm{d}, \mathrm{p})$ & 140 \\
\hline $\mathrm{F}^{-}$ & $\mathrm{C}_{6} \mathrm{H}_{4}(\mathrm{CN})_{2}$ & 14.3 & $\mathrm{MP} 2 / 6-311++\mathrm{G}(\mathrm{d}, \mathrm{p})$ & 140 \\
\hline $\mathrm{Cl}^{-}$ & Unsubstituted pyrylium cation, $\mathrm{X}=\mathrm{Se}$ & $108.2^{\mathrm{a}}$ & CCSD(T)/CBS & 38 \\
\hline $\mathrm{Cl}^{-}$ & Unsubstituted pyrylium cation, $\mathrm{X}=\mathrm{S}$ & $104.6^{\mathrm{a}}$ & CCSD(T)/CBS & 38 \\
\hline $\mathrm{Cl}^{-}$ & Unsubstituted pyrylium cation, $\mathrm{X}=\mathrm{O}$ & $98.5^{\mathrm{a}}$ & CCSD(T)/CBS & 38 \\
\hline $\mathrm{Cl}^{-}$ & 3,4-dicyano-1,2,5-telluradiazole & 54.2 & B97-D3/def2-TZVP & 37 \\
\hline $\mathrm{Cl}^{-}$ & 3,4-dicyano-1,2,5-selenadiazole & 42.3 & B97-D3/def2-TZVP & 37 \\
\hline $\mathrm{Cl}^{-}$ & $\mathrm{Se}(\mathrm{CN})_{2}$ & 33.5 & MP2/aug-cc-pVTZ & 36 \\
\hline $\mathrm{Cl}^{-}$ & 3,4-dicyano-1,2,5-sulfuradiazole & 33.0 & B97-D3/def2-TZVP & 37 \\
\hline $\mathrm{Cl}^{-}$ & $\mathrm{S}(\mathrm{CN})_{2}$ & 27.7 & MP2/aug-cc-pVTZ & 36 \\
\hline $\mathrm{Cl}^{-}$ & $\mathrm{SFCl}$ & 24.4 & MP2/aug-cc-pVTZ & 36 \\
\hline $\mathrm{Cl}^{-}$ & $\operatorname{DTT}\left(\mathrm{SO}_{2}\right)$ & $22.3^{\mathrm{a}}$ & MP2/6-311++G(d,p) & 136 \\
\hline $\mathrm{Cl}^{-}$ & $\mathrm{C}_{6} \mathrm{~F}_{4}(\mathrm{CN})_{2}$ & 20.8 & MP2/6-311++G(d,p) & 140 \\
\hline $\mathrm{Cl}^{-}$ & $\mathrm{C}_{6} \mathrm{~F}_{4} \mathrm{O}_{2}$ & 20.2 & MP2/6-311++G(d,p) & 140 \\
\hline $\mathrm{Cl}^{-}$ & DTT(O) & $14.5^{\mathrm{a}}$ & MP2/6-311++G(d,p) & 136 \\
\hline $\mathrm{Cl}^{-}$ & DTT(S) & $12.9^{\mathrm{a}}$ & MP2/6-311++G(d,p) & 136 \\
\hline $\mathrm{Cl}^{-}$ & $\mathrm{DTT}\left(\mathrm{PCH}_{3}\right)$ & $12.1^{\mathrm{a}}$ & MP2/6-311++G(d,p) & 136 \\
\hline $\mathrm{Cl}^{-}$ & $\operatorname{DTT}\left(\mathrm{CH}_{2}\right)$ & $10.9^{\mathrm{a}}$ & MP2/6-311++G(d,p) & 136 \\
\hline $\mathrm{Cl}^{-}$ & $\mathrm{C}_{6} \mathrm{H}_{4}(\mathrm{CN})_{2}$ & 10.7 & MP2/6-311++G(d,p) & 140 \\
\hline $\mathrm{Cl}^{-}$ & $\operatorname{DTT}\left(\mathrm{NCH}_{3}\right)$ & $9.9^{\mathrm{a}}$ & MP2/6-311++G(d,p) & 136 \\
\hline $\mathrm{Cl}^{-}$ & $\mathrm{C}_{6} \mathrm{H}_{4} \mathrm{O}_{2}$ & 9.3 & MP2/6-311++G(d,p) & 140 \\
\hline $\mathrm{Br}^{-}$ & 3,4-dicyano-1,2,5-telluradiazole & 46.3 & B97-D3/def2-TZVP & 37 \\
\hline $\mathrm{Br}^{-}$ & 3,4-dicyano-1,2,5-selenadiazole & 35.4 & B97-D3/def2-TZVP & 37 \\
\hline $\mathrm{Br}^{-}$ & 3,4-dicyano-1,2,5-sulfuradiazole & 29.1 & B97-D3/def2-TZVP & 37 \\
\hline $\mathrm{I}^{-}$ & 3,4-dicyano-1,2,5-telluradiazole & 39.8 & B97-D3/def2-TZVP & 37 \\
\hline $\mathrm{I}^{-}$ & 3,4-dicyano-1,2,5-selenadiazole & 29.8 & B97-D3/def2-TZVP & 37 \\
\hline$\overline{\mathrm{I}^{-}}$ & 3,4-dicyano-1,2,5-sulfuradiazole & 25.0 & B97-D3/def2-TZVP & 37 \\
\hline
\end{tabular}




\begin{tabular}{|c|c|c|c|c|}
\hline \multicolumn{5}{|c|}{ polyatomic anion } \\
\hline $\begin{array}{l}\left(\mathrm{o}-\mathrm{CH}_{3^{-}}\right. \\
\mathrm{PhSe})_{2}^{--}\end{array}$ & dimer & 94.9 & MP2/6-311++G(d,p) & 40 \\
\hline$(\mathrm{PhSe})_{2}^{\cdot-}$ & dimer & 94.2 & MP2/6-311++G(d,p) & 40 \\
\hline$(\mathrm{PhS})_{2}{ }^{-}$ & dimer & 69.6 & MP2/6-311++G(d,p) & 40 \\
\hline$\left(\mathrm{PhCH}_{2} \mathrm{~S}\right)_{2}{ }^{\cdot-}$ & dimer & 68.8 & MP2/6-311++G(d,p) & 40 \\
\hline$\left(\mathrm{PhCH}_{2} \mathrm{Se}\right)_{2}{ }^{-}$ & dimer & 62.8 & MP2/6-311++G(d,p) & 40 \\
\hline $\begin{array}{l}\left(\mathrm{o}-\mathrm{NO}_{2-}^{-}\right. \\
\mathrm{PhSe})_{2}^{-}\end{array}$ & dimer & 60.7 & MP2/6-311++G(d,p) & 40 \\
\hline $\mathrm{CN}^{-}$ & 3,4-di-cyano-1,2,5-telluradiazoles & 52.3 & B97-D3/def2-TZVP & 39 \\
\hline $\mathrm{NC}^{-}$ & 3,4-di-cyano-1,2,5-telluradiazoles & 48.0 & B97-D3/def2-TZVP & 39 \\
\hline $\mathrm{NC}^{-}$ & 3,4-di-cyano-1,2,5-telluradiazoles & 47.1 & B97-D3/def2-TZVP & 39 \\
\hline $\mathrm{SPh}^{-}$ & 3,4-dicyano-1,2,5-telluradiazole & 50.1 & B97-D3/def2-TZVP & 37 \\
\hline $\mathrm{SPh}^{-}$ & 3,4-dicyano-1,2,5-selenadiazole & 39.1 & B97-D3/def2-TZVP & 37 \\
\hline $\mathrm{SPh}^{-}$ & 3,4-dicyano-1,2,5-sulfuradiazole & 31.7 & B97-D3/def2-TZVP & 37 \\
\hline $\mathrm{SCN}^{-}$ & 3,4-di-cyano-1,2,5-telluradiazoles & 40.6 & B97-D3/def2-TZVP & 39 \\
\hline $\mathrm{NCS}^{-}$ & 3,4-di-cyano-1,2,5-telluradiazoles & 40.1 & B97-D3/def2-TZVP & 39 \\
\hline $\mathrm{SeCN}^{-}$ & 3,4-di-cyano-1,2,5-telluradiazoles & 39.8 & B97-D3/def2-TZVP & 39 \\
\hline $\mathrm{NCSe}^{-}$ & 3,4-di-cyano-1,2,5-telluradiazoles & 37.1 & B97-D3/def2-TZVP & 39 \\
\hline $\mathrm{OCN}^{-}$ & 3,4-di-cyano-1,2,5-telluradiazoles & 38.7 & B97-D3/def2-TZVP & 39 \\
\hline $\mathrm{TeCN}^{-}$ & 3,4-di-cyano-1,2,5-telluradiazoles & 37.0 & B97-D3/def2-TZVP & 39 \\
\hline
\end{tabular}

a interaction energy 
Table 6 Calculated binding energies between anion and a single ligand in halogen bonded clusters.

\begin{tabular}{|c|c|c|c|c|}
\hline anion & ligand & $-\mathrm{E}_{\mathrm{b}}, \mathrm{kcal} / \mathrm{mol}$ & level of theory & ref. \\
\hline \multicolumn{5}{|c|}{ monoatomic anion } \\
\hline $\mathrm{F}^{-}$ & $\mathrm{CH}_{3} \mathrm{OCFCl}^{+}$ & 119.17 & M05-2X/6-311++G(d,p) & 52 \\
\hline $\mathrm{F}^{-}$ & $\mathrm{CH}_{3} \mathrm{OCHCl}^{+}$ & 115.50 & M05-2X/6-311++G(d,p) & 52 \\
\hline $\mathrm{F}^{-}$ & $\mathrm{CH}_{3} \mathrm{OClCl}^{+}$ & 113.18 & M05-2X/6-311++G(d,p) & 52 \\
\hline $\mathrm{F}^{-}$ & CN-Quin_II-Br & $101.77^{\mathrm{a}}$ & $\omega B 97 X D /$ aug-cc-pVTZ & 61 \\
\hline $\mathrm{F}^{-}$ & H-Quin_II-Br & $93.42^{\mathrm{a}}$ & $\omega B 97 X D /$ aug-cc-pVTZ & 61 \\
\hline $\mathrm{F}^{-}$ & CN-Quin_I-Br & $87.09^{\mathrm{a}}$ & $\omega B 97 X D /$ aug-cc-pVTZ & 61 \\
\hline $\mathrm{F}^{-}$ & CN-Quin_II-Cl & $86.83^{\mathrm{a}}$ & $\omega \mathrm{B} 97 X \mathrm{X} /$ aug-cc-pVTZ & 61 \\
\hline $\mathrm{F}^{-}$ & H-Quin_I-Br & $79.98^{\mathrm{a}}$ & $\omega B 97 X D /$ aug-cc-pVTZ & 61 \\
\hline $\mathrm{F}^{-}$ & H-Quin_II-Cl & $79.05^{\mathrm{a}}$ & $\omega B 97 X D /$ aug-cc-pVTZ & 61 \\
\hline $\mathrm{F}^{-}$ & CN-Quin_I-Cl & $73.86^{\mathrm{a}}$ & $\omega B 97 X D /$ aug-cc-pVTZ & 61 \\
\hline $\mathrm{F}^{-}$ & H-Quin_I-Cl & $67.44^{\mathrm{a}}$ & $\omega B 97 X D /$ aug-cc-pVTZ & 61 \\
\hline $\mathrm{F}^{-}$ & $\mathrm{C}_{3} \mathrm{H}_{2} \mathrm{~N}_{3} \mathrm{I}$ & 32.27 & MP2/CBS & 151 \\
\hline $\mathrm{F}^{-}$ & $\mathrm{C}_{3} \mathrm{H}_{2} \mathrm{~N}_{3} \mathrm{Br}$ & 20.41 & $\mathrm{MP} 2 / \mathrm{CBS}$ & 151 \\
\hline $\mathrm{F}^{-}$ & $\mathrm{C}_{3} \mathrm{H}_{2} \mathrm{~N}_{3} \mathrm{Cl}$ & 13.09 & MP2/CBS & 151 \\
\hline $\mathrm{Cl}^{-}$ & $\mathrm{CH}_{3} \mathrm{OCFCl}^{+}$ & 95.66 & M05-2X/6-311++G(d,p) & 52 \\
\hline $\mathrm{Cl}^{-}$ & $\mathrm{CH}_{3} \mathrm{OCHCl}^{+}$ & 94.44 & M05-2X/6-311++G(d,p) & 52 \\
\hline $\mathrm{Cl}^{-}$ & $\mathrm{CH}_{3} \mathrm{OClCl}^{+}$ & 92.89 & M05-2X/6-311++G(d,p) & 52 \\
\hline $\mathrm{Cl}^{-}$ & $\begin{array}{l}\text { 2-halo-1H-imidazol } \\
\text {-3-ium } \mathrm{Br} \text { derivative }\end{array}$ & $87.00^{\mathrm{a}}$ & CCSD(T)/aug-cc-pVDZ & 147 \\
\hline $\mathrm{Cl}^{-}$ & CN-Quin_II-Br & $78.36^{\mathrm{a}}$ & $\omega B 97 X D /$ aug-cc-pVTZ & 61 \\
\hline $\mathrm{Cl}^{-}$ & H-Quin_II-Br & $71.08^{\mathrm{a}}$ & $\omega B 97 X D /$ aug-cc-pVTZ & 61 \\
\hline $\mathrm{Cl}^{-}$ & CN-Quin_II-Cl & $67.47^{\mathrm{a}}$ & $\omega B 97 X D /$ aug-cc-pVTZ & 61 \\
\hline $\mathrm{Cl}^{-}$ & CN-Quin_I-Br & $66.49^{\mathrm{a}}$ & $\omega B 97 X D /$ aug-cc-pVTZ & 61 \\
\hline $\mathrm{Cl}^{-}$ & H-Quin_II-Cl & $61.48^{\mathrm{a}}$ & $\omega B 97 X D /$ aug-cc-pVTZ & 61 \\
\hline $\mathrm{Cl}^{-}$ & H-Quin_I-Br & $60.69^{\mathrm{a}}$ & $\omega B 97 X D /$ aug-cc-pVTZ & 61 \\
\hline $\mathrm{Cl}^{-}$ & CN-Quin_I-Cl & $58.32^{\mathrm{a}}$ & $\omega B 97 X D /$ aug-cc-pVTZ & 61 \\
\hline $\mathrm{Cl}^{-}$ & H-Quin_I-Cl & $53.40^{\mathrm{a}}$ & $\omega B 97 X D /$ aug-cc-pVTZ & 61 \\
\hline $\mathrm{Cl}^{-}$ & $\mathrm{BrF}$ & $53.1^{\mathrm{a}}$ & CCSD(T)/aug-cc-pVTZ & 26 \\
\hline $\mathrm{Cl}^{-}$ & $\mathrm{C}_{3} \mathrm{H}_{2} \mathrm{~N}_{3} \mathrm{I}$ & 17.75 & $\mathrm{MP} 2 / \mathrm{CBS}$ & 151 \\
\hline $\mathrm{Cl}^{-}$ & $\mathrm{I}_{2}$ & $34^{\mathrm{a}}$ & M06-2X/aug-cc-pVTZ & 150 \\
\hline $\mathrm{Cl}^{-}$ & $\mathrm{C}_{6} \mathrm{~F}_{5} \mathrm{I}$ & $23.80^{\mathrm{a}}$ & MP2/aug-cc-pVDZ & 51 \\
\hline $\mathrm{Cl}^{-}$ & $\mathrm{C}_{2} \mathrm{~F}_{3} \mathrm{I}$ & $23.19^{\mathrm{a}}$ & MP2/aug-cc-pVDZ & 51 \\
\hline $\mathrm{Cl}^{-}$ & iodoimidazolium & 10.6 & B3LYP/SVP & 148 \\
\hline $\mathrm{Cl}^{-}$ & $\mathrm{C}_{3} \mathrm{H}_{2} \mathrm{~N}_{3} \mathrm{Br}$ & 10.52 & $\mathrm{MP} 2 / \mathrm{CBS}$ & 151 \\
\hline $\mathrm{Cl}^{-}$ & imidazolium & 7.4 & B3LYP/SVP & 148 \\
\hline $\mathrm{Cl}^{-}$ & tetracyanopyrazine & $6.71^{\mathrm{a}}$ & M062X/def2tzvpp & 59 \\
\hline
\end{tabular}




\begin{tabular}{|c|c|c|c|c|}
\hline $\mathrm{Cl}^{-}$ & $\mathrm{C}_{3} \mathrm{H}_{2} \mathrm{~N}_{3} \mathrm{Cl}$ & 6.44 & MP2/CBS & 151 \\
\hline $\mathrm{Br}^{-}$ & $\mathrm{CH}_{3} \mathrm{OCFCl}^{+}$ & 93.89 & M05-2X/6-311++G(d,p) & 52 \\
\hline $\mathrm{Br}^{-}$ & $\mathrm{CH}_{3} \mathrm{OCHCl}^{+}$ & 92.27 & M05-2X/6-311++G(d,p) & 52 \\
\hline $\mathrm{Br}^{-}$ & $\mathrm{CH}_{3} \mathrm{OClCl}^{+}$ & 90.96 & M05-2X/6-311++G(d,p) & 52 \\
\hline $\mathrm{Br}^{-}$ & CN-Quin_II-Br & $74.53^{\mathrm{a}}$ & $\omega \mathrm{B} 97 \mathrm{XD} /$ aug-cc-pVTZ & 61 \\
\hline $\mathrm{Br}^{-}$ & $\mathrm{I}_{2}$ & $69^{a}$ & M06-2X/aug-cc-pVTZ & 150 \\
\hline $\mathrm{Br}^{-}$ & H-Quin_II-Br & $67.35^{\mathrm{a}}$ & $\omega \mathrm{B} 97 \mathrm{XD} /$ aug-cc-pVTZ & 61 \\
\hline $\mathrm{Br}^{-}$ & CN-Quin_II-Cl & $64.20^{\mathrm{a}}$ & $\omega B 97 X D /$ aug-cc-pVTZ & 61 \\
\hline $\mathrm{Br}^{-}$ & CN-Quin_I-Br & $63.05^{\mathrm{a}}$ & $\omega B 97 X D /$ aug-cc-pVTZ & 61 \\
\hline $\mathrm{Br}^{-}$ & H-Quin_II-Cl & $58.50^{\mathrm{a}}$ & $\omega B 97 X D /$ aug-cc-pVTZ & 61 \\
\hline $\mathrm{Br}^{-}$ & H-Quin_I-Br & $57.48^{\mathrm{a}}$ & $\omega$ B97XD/aug-cc-pVTZ & 61 \\
\hline $\mathrm{Br}^{-}$ & CN-Quin_I-Cl & $55.71^{\mathrm{a}}$ & $\omega B 97 X D /$ aug-cc-pVTZ & 61 \\
\hline $\mathrm{Br}^{-}$ & H-Quin_I-Cl & $51.05^{\mathrm{a}}$ & $\omega \mathrm{B} 97 \mathrm{XD} /$ aug-cc-pVTZ & 61 \\
\hline $\mathrm{Br}^{-}$ & $\mathrm{HF}$ & $23.0^{\mathrm{a}}$ & CCSD(T)/aug-cc-pVTZ & 26 \\
\hline $\mathrm{Br}^{-}$ & $\mathrm{C}_{6} \mathrm{~F}_{5} \mathrm{I}$ & $21.00^{\mathrm{a}}$ & MP2/aug-cc-pVDZ & 51 \\
\hline $\mathrm{Br}^{-}$ & $\mathrm{C}_{2} \mathrm{~F}_{3} \mathrm{I}$ & $20.40^{\mathrm{a}}$ & MP2/aug-cc-pVDZ & 51 \\
\hline $\mathrm{Br}^{-}$ & $\mathrm{CF}_{3} \mathrm{Br}$ & $16.83^{\mathrm{a}}$ & CCSD(T)/lanl2DZ* & 62 \\
\hline $\mathrm{Br}^{-}$ & $\mathrm{C}_{3} \mathrm{H}_{2} \mathrm{~N}_{3} \mathrm{I}$ & 15.36 & $\mathrm{MP} 2 / \mathrm{CBS}$ & 151 \\
\hline $\mathrm{Br}^{-}$ & $\mathrm{F}_{3} \mathrm{C}-\mathrm{Br}$ & $11.95^{\mathrm{a}}$ & MP2/aug-cc-pVDZ & 32 \\
\hline $\mathrm{Br}^{-}$ & $\mathrm{HC} \equiv \mathrm{C}-\mathrm{Br}$ & $10.47^{\mathrm{a}}$ & MP2/aug-cc-pVDZ & 32 \\
\hline $\mathrm{Br}^{-}$ & $\mathrm{C}_{3} \mathrm{H}_{2} \mathrm{~N}_{3} \mathrm{Br}$ & 8.91 & $\mathrm{MP} 2 / \mathrm{CBS}$ & 151 \\
\hline $\mathrm{Br}^{-}$ & 4-pyridyl-Br & $8.11^{\mathrm{a}}$ & MP2/aug-cc-pVDZ & 32 \\
\hline $\mathrm{Br}^{-}$ & 3-pyridyl-Br & $7.30^{\mathrm{a}}$ & MP2/aug-cc-pVDZ & 32 \\
\hline $\mathrm{Br}^{-}$ & $\mathrm{F}_{2} \mathrm{CH}-\mathrm{Br}$ & $6.87^{\mathrm{a}}$ & MP2/aug-cc-pVDZ & 32 \\
\hline $\mathrm{Br}^{-}$ & tetracyanopyrazine & $6.42^{\mathrm{a}}$ & M062X/def2tzvpp & 59 \\
\hline $\mathrm{Br}^{-}$ & 4-F-phenyl-Br & $6.35^{\mathrm{a}}$ & MP2/aug-cc-pVDZ & 32 \\
\hline $\mathrm{Br}^{-}$ & $\mathrm{C}_{3} \mathrm{H}_{2} \mathrm{~N}_{3} \mathrm{Cl}$ & 5.37 & $\mathrm{MP} 2 / \mathrm{CBS}$ & 151 \\
\hline $\mathrm{Br}^{-}$ & Phenyl-Br & $4.52^{\mathrm{a}}$ & MP2/aug-cc-pVDZ & 32 \\
\hline $\mathrm{Br}^{-}$ & $\mathrm{FCH}_{2}-\mathrm{Br}$ & $4.45^{\mathrm{a}}$ & MP2/aug-cc-pVDZ & 32 \\
\hline $\mathrm{Br}^{-}$ & 2-pyridyl-Br & $3.66^{\mathrm{a}}$ & MP2/aug-cc-pVDZ & 32 \\
\hline $\mathrm{Br}^{-}$ & $\mathrm{H}_{2} \mathrm{C}=\mathrm{CH}-\mathrm{Br}$ & $3.51^{\mathrm{a}}$ & MP2/aug-cc-pVDZ & 32 \\
\hline $\mathrm{Br}^{-}$ & 4- $\mathrm{NH}_{2}$-phenyl-Br & $3.13^{\mathrm{a}}$ & MP2/aug-cc-pVDZ & 32 \\
\hline $\mathrm{Br}^{-}$ & $\mathrm{CH}_{3} \mathrm{Br}$ & $2.39^{\mathrm{a}}$ & CCSD(T)/lanl2DZ* & 62 \\
\hline $\mathrm{Br}^{-}$ & $\mathrm{H}_{3} \mathrm{C}-\mathrm{Br}$ & $0.89^{\mathrm{a}}$ & MP2/aug-cc-pVDZ & 32 \\
\hline $\mathrm{I}^{-}$ & $\mathrm{I}_{2}$ & $38^{\mathrm{a}}$ & M06-2X/aug-cc-pVTZ & 150 \\
\hline $\mathrm{I}^{-}$ & $\mathrm{CF}_{3} \mathrm{I}$ & $19.08^{\mathrm{a}}$ & CCSD(T)/lanl2DZ* & 62 \\
\hline $\mathrm{I}^{-}$ & $\mathrm{C}_{6} \mathrm{~F}_{5} \mathrm{I}$ & $17.66^{\mathrm{a}}$ & MP2/aug-cc-pVDZ & 51 \\
\hline $\mathrm{I}^{-}$ & $\mathrm{C}_{2} \mathrm{~F}_{3} \mathrm{I}$ & $17.11^{\mathrm{a}}$ & MP2/aug-cc-pVDZ & 51 \\
\hline $\mathrm{I}^{-}$ & $\mathrm{C}_{3} \mathrm{H}_{2} \mathrm{~N}_{3} \mathrm{I}$ & 12.91 & $\mathrm{MP} 2 / \mathrm{CBS}$ & 151 \\
\hline $\mathrm{I}^{-}$ & $\mathrm{C}_{3} \mathrm{H}_{2} \mathrm{~N}_{3} \mathrm{Br}$ & 7.21 & $\mathrm{MP} 2 / \mathrm{CBS}$ & 151 \\
\hline
\end{tabular}




\begin{tabular}{|c|c|c|c|c|}
\hline $\mathrm{I}^{-}$ & tetracyanopyrazine & $6.06^{\mathrm{a}}$ & M062X/def2tzvpp & 59 \\
\hline $\mathrm{I}^{-}$ & $\mathrm{CH}_{3} \mathrm{I}$ & $4.86^{\mathrm{a}}$ & CCSD(T)/lanl2DZ* & 62 \\
\hline $\mathrm{I}^{-}$ & $\mathrm{C}_{3} \mathrm{H}_{2} \mathrm{~N}_{3} \mathrm{Cl}$ & 4.23 & MP2/CBS & 151 \\
\hline \multicolumn{5}{|c|}{ polyatomic anion } \\
\hline $\mathrm{NC}^{-}$ & CN-Quin_II-Br & $73.76^{\mathrm{a}}$ & $\omega B 97 X D /$ aug-cc-pVTZ & 61 \\
\hline $\mathrm{NC}^{-}$ & H-Quin_II-Br & $67.25^{\mathrm{a}}$ & $\omega B 97 X D /$ aug-cc-pVTZ & 61 \\
\hline $\mathrm{NC}^{-}$ & CN-Quin_II-Cl & $63.72^{\mathrm{a}}$ & $\omega B 97 X D /$ aug-cc-pVTZ & 61 \\
\hline $\mathrm{NC}^{-}$ & CN-Quin_I-Br & $63.01^{\mathrm{a}}$ & $\omega B 97 X D /$ aug-cc-pVTZ & 61 \\
\hline $\mathrm{NC}^{-}$ & H-Quin_II-Cl & $58.47^{\mathrm{a}}$ & $\omega B 97 X D /$ aug-cc-pVTZ & 61 \\
\hline $\mathrm{NC}^{-}$ & H-Quin_I-Br & $57.78^{\mathrm{a}}$ & $\omega B 97 X D /$ aug-cc-pVTZ & 61 \\
\hline $\mathrm{NC}^{-}$ & CN-Quin_I-Cl & $55.92^{\mathrm{a}}$ & $\omega B 97 X D /$ aug-cc-pVTZ & 61 \\
\hline $\mathrm{NC}^{-}$ & H-Quin_I-Cl & $51.51^{\mathrm{a}}$ & $\omega B 97 X D /$ aug-cc-pVTZ & 61 \\
\hline $\mathrm{CN}^{-}$ & $\mathrm{F}_{3} \mathrm{C}-\mathrm{Br}$ & $13.68^{\mathrm{a}}$ & MP2/aug-cc-pVDZ & 32 \\
\hline $\mathrm{CN}^{-}$ & $\mathrm{HC} \equiv \mathrm{C}-\mathrm{Br}$ & $12.36^{\mathrm{a}}$ & MP2/aug-cc-pVDZ & 32 \\
\hline $\mathrm{CN}^{-}$ & 4-pyridyl-Br & $9.40^{\mathrm{a}}$ & MP2/aug-cc-pVDZ & 32 \\
\hline $\mathrm{CN}^{-}$ & $\mathrm{F}_{2} \mathrm{CH}-\mathrm{Br}$ & $9.37^{\mathrm{a}}$ & MP2/aug-cc-pVDZ & 32 \\
\hline $\mathrm{CN}^{-}$ & 3-pyridyl-Br & $8.60^{\mathrm{a}}$ & MP2/aug-cc-pVDZ & 32 \\
\hline $\mathrm{CN}^{-}$ & 4-F-phenyl-Br & $7.61^{\mathrm{a}}$ & MP2/aug-cc-pVDZ & 32 \\
\hline $\mathrm{CN}^{-}$ & Phenyl-Br & $5.78^{\mathrm{a}}$ & MP2/aug-cc-pVDZ & 32 \\
\hline $\mathrm{CN}^{-}$ & $\mathrm{FCH}_{2}-\mathrm{Br}$ & $5.77^{\mathrm{a}}$ & MP2/aug-cc-pVDZ & 32 \\
\hline $\mathrm{CN}^{-}$ & 2-pyridyl-Br & $4.95^{\mathrm{a}}$ & MP2/aug-cc-pVDZ & 32 \\
\hline $\mathrm{CN}^{-}$ & $\mathrm{H}_{2} \mathrm{C}=\mathrm{CH}-\mathrm{Br}$ & $4.81^{\mathrm{a}}$ & MP2/aug-cc-pVDZ & 32 \\
\hline $\mathrm{CN}^{-}$ & 4-NH -phenyl-Br & $4.40^{\mathrm{a}}$ & MP2/aug-cc-pVDZ & 32 \\
\hline $\mathrm{CN}^{-}$ & $\mathrm{H}_{3} \mathrm{C}-\mathrm{Br}$ & $1.05^{\mathrm{a}}$ & MP2/aug-cc-pVDZ & 32 \\
\hline $\mathrm{NCS}^{-}$ & $\mathrm{CBr}_{4}$ & $12.2^{\mathrm{a}}$ & $\mathrm{M} 062 \mathrm{X} / 6-311+\mathrm{G}(\mathrm{d}, \mathrm{p})$ & 66 \\
\hline $\mathrm{BF}_{4}^{-}$ & $\mathrm{NCN}$ & $41.7^{\mathrm{a}}$ & BP86-D3/def2-TZVP & 149 \\
\hline $\mathrm{BF}_{4}^{-}$ & NPy & $32.6^{\mathrm{a}}$ & BP86-D3/def2-TZVP & 149 \\
\hline $\mathrm{NO}_{3}{ }^{-}$ & $\mathrm{I}_{2}$ & $34^{\mathrm{a}}$ & M06-2X/aug-cc-pVTZ & 150 \\
\hline $\mathrm{Ac}^{-}$ & $\mathrm{I}_{2}$ & $34^{\mathrm{a}}$ & M06-2X/aug-cc-pVTZ & 150 \\
\hline $\mathrm{ClO}_{4}^{-}$ & $\mathrm{I}_{2}$ & $24^{\mathrm{a}}$ & M06-2X/aug-cc-pVTZ & 150 \\
\hline $\mathrm{PF}_{6}$ & $\mathrm{I}_{2}$ & $24^{\mathrm{a}}$ & M06-2X/aug-cc-pVTZ & 150 \\
\hline $\mathrm{TfO}^{-}$ & $\mathrm{I}_{2}$ & $20^{\mathrm{a}}$ & M06-2X/aug-cc-pVTZ & 150 \\
\hline $\mathrm{NCS}^{-}$ & sym- $-\mathrm{C}_{6} \mathrm{~F}_{3} \mathrm{I}_{3}$ & $16.97^{\mathrm{a}}$ & B3LYP/6-311++G(d,p) & 64 \\
\hline$\left[\mathrm{Zn}(\mathrm{NCS})_{4}\right]^{2-}$ & $\mathrm{CBr}_{4}$ & $12.1^{\mathrm{a}}$ & $\mathrm{M} 062 \mathrm{X} / 6-311+\mathrm{G}(\mathrm{d}, \mathrm{p})$ & 66 \\
\hline
\end{tabular}

a interaction energy 
Table 7 Binding energies $(\mathrm{kcal} / \mathrm{mol})$ for complexes of neutral, singly and doubly charged BTP with different halide anions.

\begin{tabular}{|l|l|l|l|l|}
\hline anion $\mathrm{Y}^{-}$ & $2 \mathrm{H}$ & $2 \mathrm{Cl}$ & $2 \mathrm{Br}$ & $2 \mathrm{I}$ \\
\hline \multicolumn{5}{|c|}{ neutral BTP } \\
\hline $\mathrm{F}^{-}$ & 9.70 & 4.20 & 10.18 & 16.02 \\
\hline $\mathrm{Cl}^{-}$ & 5.44 & 3.26 & 6.77 & 10.33 \\
\hline $\mathrm{Br}^{-}$ & 4.77 & 3.24 & 6.55 & 9.88 \\
\hline $\mathrm{I}^{-}$ & 4.10 & 3.21 & 6.30 & 9.37 \\
\hline \multicolumn{5}{|c|}{ monocation BTP } \\
\hline $\mathrm{F}^{-}$ & 13.18 & 5.93 & 12.38 & 18.83 \\
\hline $\mathrm{Cl}^{-}$ & 7.35 & 4.34 & 8.22 & 12.16 \\
\hline $\mathrm{Br}^{-}$ & 6.42 & 4.23 & 7.88 & 11.59 \\
\hline $\mathrm{I}^{-}$ & 5.47 & 4.10 & 7.47 & 10.94 \\
\hline \multicolumn{5}{|l|}{ dication BTP } \\
\hline $\mathrm{F}^{-}$ & 11.12 & 9.11 & 16.87 & 24.13 \\
\hline $\mathrm{Cl}^{-}$ & 8.57 & 6.11 & 10.81 & 15.49 \\
\hline $\mathrm{Br}^{-}$ & 7.77 & 5.82 & 10.28 & 14.61 \\
\hline $\mathrm{I}^{-}$ & 6.74 & 5.50 & 9.60 & 13.66 \\
\hline
\end{tabular}


Table 8 Preference of halide anion for halogenated vs H-bonding agent expressed as equilibrium ratio

\begin{tabular}{|l|r|r|r|}
\hline & \multicolumn{2}{|l|}{$2 \mathrm{Cl}$} & $2 \mathrm{Br}$ \\
\hline & \multicolumn{1}{|l|}{ neutral BTP } \\
\hline $\mathrm{F}^{-}$ & $7.92 \mathrm{E}-05$ & $2.70 \mathrm{E}+00$ & $5.62 \mathrm{E}+03$ \\
\hline $\mathrm{Cl}^{-}$ & $1.04 \mathrm{E}-01$ & $3.88 \mathrm{E}+01$ & $6.60 \mathrm{E}+02$ \\
\hline $\mathrm{Br}^{-}$ & $9.51 \mathrm{E}-01$ & $1.68 \mathrm{E}+02$ & $1.76 \mathrm{E}+03$ \\
\hline $\mathrm{I}^{-}$ & $8.51 \mathrm{E}+00$ & $1.88 \mathrm{E}+03$ & $3.30 \mathrm{E}+04$ \\
\hline \multicolumn{4}{|c|}{ monocation BTP } \\
\hline $\mathrm{F}^{-}$ & $8.07 \mathrm{E}-07$ & $2.47 \mathrm{E}-01$ & $5.08 \mathrm{E}+03$ \\
\hline $\mathrm{Cl}^{-}$ & $1.57 \mathrm{E}-03$ & $1.52 \mathrm{E}+00$ & $3.91 \mathrm{E}+02$ \\
\hline $\mathrm{Br}^{-}$ & $6.19 \mathrm{E}-02$ & $2.61 \mathrm{E}+02$ & $1.18 \mathrm{E}+04$ \\
\hline $\mathrm{I}^{-}$ & $1.85 \mathrm{E}-01$ & $3.62 \mathrm{E}+03$ & $1.06 \mathrm{E}+05$ \\
\hline \multicolumn{4}{|r|}{ dication BTP } \\
\hline $\mathrm{F}^{-}$ & $1.44 \mathrm{E}-05$ & $7.31 \mathrm{E}+00$ & $1.87 \mathrm{E}+07$ \\
\hline $\mathrm{Cl}^{-}$ & $5.46 \mathrm{E}-03$ & $3.88 \mathrm{E}+01$ & $2.41 \mathrm{E}+05$ \\
\hline $\mathrm{Br}^{-}$ & $2.75 \mathrm{E}-02$ & $9.98 \mathrm{E}+01$ & $4.82 \mathrm{E}+05$ \\
\hline $\mathrm{I}^{-}$ & $3.90 \mathrm{E}-03$ & $1.76 \mathrm{E}+01$ & $3.71 \mathrm{E}+04$ \\
\hline
\end{tabular}

Table 9 Selectivity of binding agent for $\mathrm{F}^{-}$over other halogen anions, expressed as equilibrium ratio

\begin{tabular}{|l|r|r|r|r|}
\hline & \multicolumn{1}{|l|}{$2 \mathrm{H}$} & \multicolumn{2}{l|}{$2 \mathrm{Br}$} & $2 \mathrm{I}$ \\
\hline & \multicolumn{1}{|l|}{ neutral BTP } \\
\hline $\mathrm{Cl}^{-}$ & $5.48 \mathrm{E}+02$ & $4.16 \mathrm{E}-01$ & $3.82 \mathrm{E}+01$ & $4.67 \mathrm{E}+03$ \\
\hline $\mathrm{Br}^{-}$ & $2.26 \mathrm{E}+03$ & $1.88 \mathrm{E}-01$ & $3.63 \mathrm{E}+01$ & $7.24 \mathrm{E}+03$ \\
\hline $\mathrm{I}^{-}$ & $3.59 \mathrm{E}+04$ & $3.34 \mathrm{E}-01$ & $5.17 \mathrm{E}+01$ & $6.11 \mathrm{E}+03$ \\
\hline \multicolumn{4}{|r|}{ monocation BTP } \\
\hline $\mathrm{Cl}^{-}$ & $2.63 \mathrm{E}+03$ & $1.35 \mathrm{E}+00$ & $4.26 \mathrm{E}+02$ & $3.41 \mathrm{E}+04$ \\
\hline $\mathrm{Br}^{-}$ & $1.46 \mathrm{E}+05$ & $1.90 \mathrm{E}+00$ & $1.38 \mathrm{E}+02$ & $6.26 \mathrm{E}+04$ \\
\hline $\mathrm{I}^{-}$ & $3.19 \mathrm{E}+06$ & $1.39 \mathrm{E}+01$ & $2.17 \mathrm{E}+02$ & $1.53 \mathrm{E}+05$ \\
\hline \multicolumn{5}{|r|}{ dication BTP+2 } \\
\hline $\mathrm{Cl}^{-}$ & $1.08 \mathrm{E}+04$ & $2.87 \mathrm{E}+01$ & $2.04 \mathrm{E}+03$ & $8.41 \mathrm{E}+05$ \\
\hline $\mathrm{Br}^{-}$ & $2.74 \mathrm{E}+04$ & $1.44 \mathrm{E}+01$ & $2.01 \mathrm{E}+03$ & $1.06 \mathrm{E}+06$ \\
\hline $\mathrm{I}^{-}$ & $4.08 \mathrm{E}+03$ & $1.51 \mathrm{E}+01$ & $1.70 \mathrm{E}+03$ & $2.05 \mathrm{E}+06$ \\
\hline
\end{tabular}



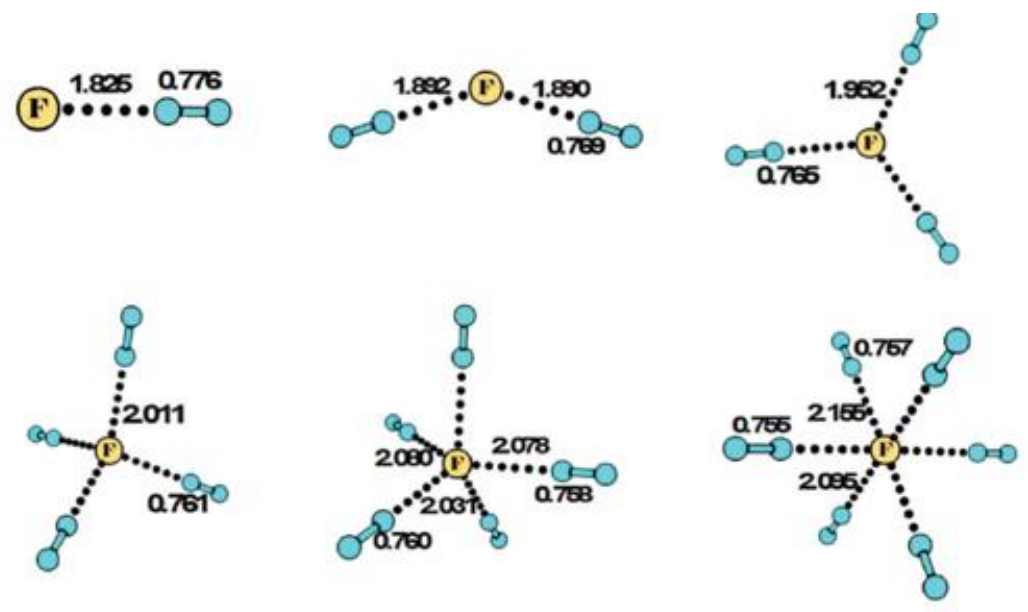

Fig. 1 Structures of $\mathrm{F}^{-\cdots}\left(\mathrm{H}_{2}\right)_{\mathrm{n}}(\mathrm{n}=1-6)$ complexes (from ref [12]). Distances given in $\AA$.
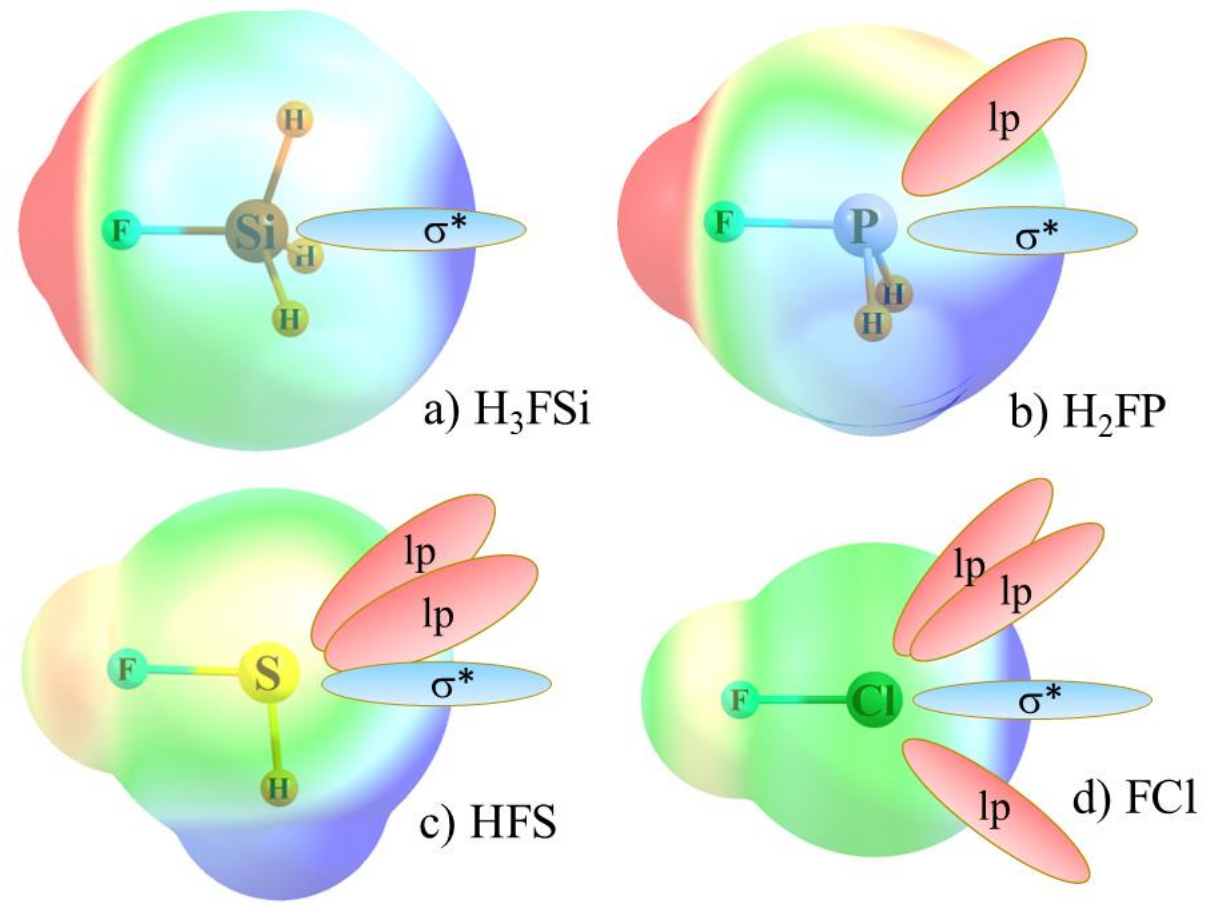

Fig. 2 Molecular electrostatic potential of four molecules, each with a $\sigma$-hole. Positive potential is denoted by blue regions, and negative in red. The light blue oval represents the lobe of each $\sigma^{*}(\mathrm{~F}-\mathrm{A})$ orbital that lies directly opposite the F-A bond. Idealized positions of A lone pairs are indicted as red ovals. 

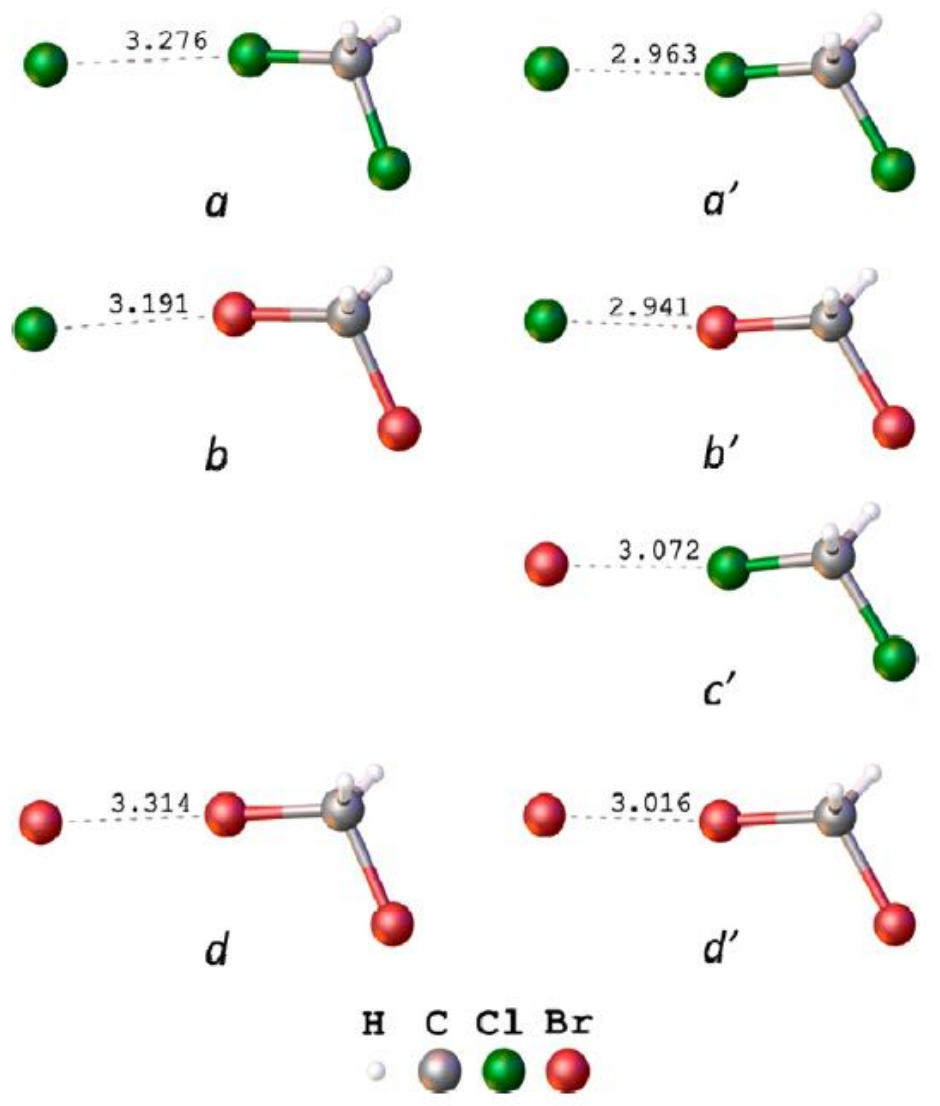

Fig. 3. Geometries derived from experiment (on the left) and DFT calculations on the right for indicated $\mathrm{H}_{2} \mathrm{XC}-\mathrm{X} \cdots \mathrm{Y}^{-}$pairs [34].
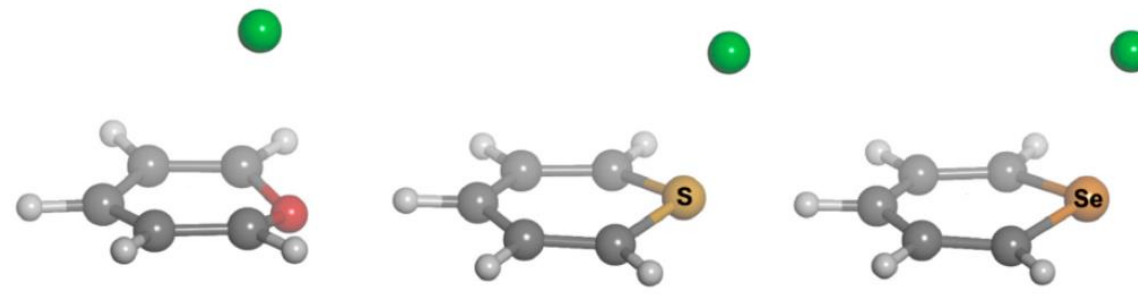

Fig. 4. Sample structures pairing $\mathrm{Cl}^{-}$with substituted pyrylium cations [38]. 

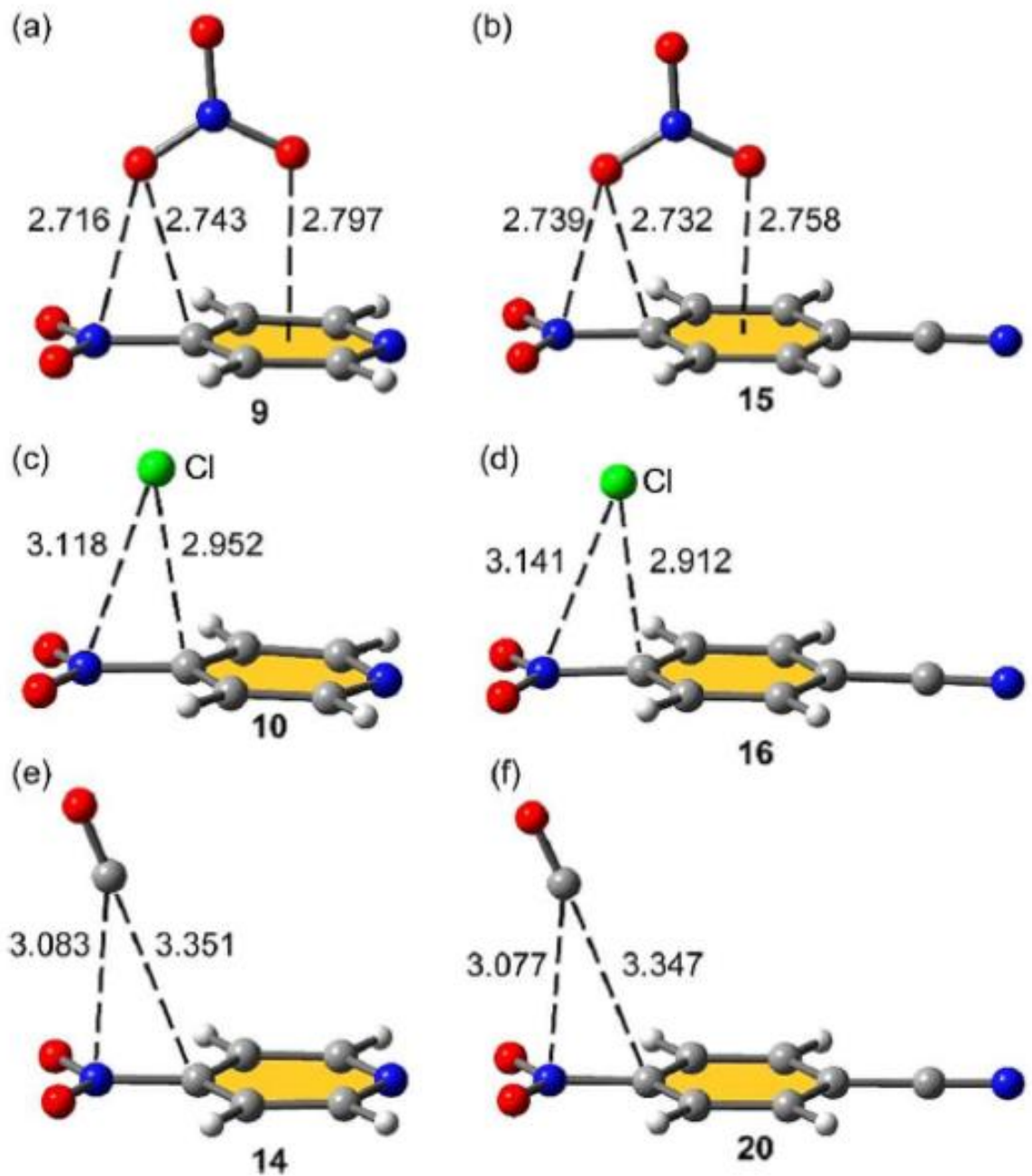

Fig. 5. Geometries of complexes of $\mathrm{NO}_{3}{ }^{-}, \mathrm{Cl}^{-}$or $\mathrm{CO}$ paired with indicated $-\mathrm{NO}_{2}$ bearing molecules [54]. Distances in A. 


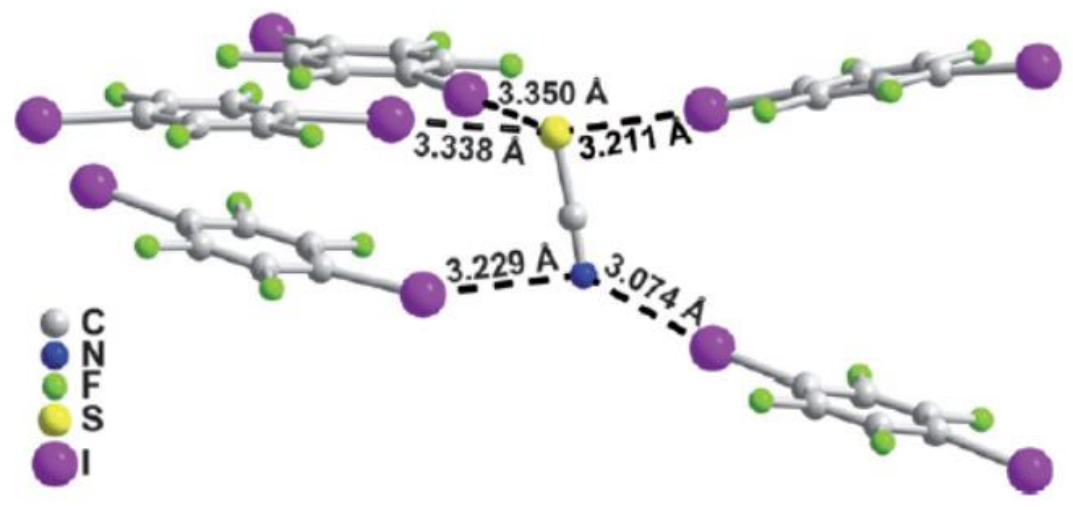

Fig. 6 Halogen bond network surrounding the $\mathrm{SCN}^{-}$anion within the crystal structure [64].

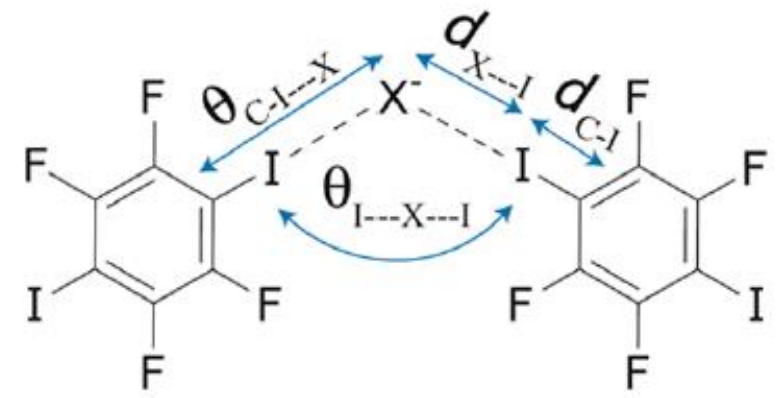

Fig. 7 Geometry of a pair of $\mathrm{C}_{6} \mathrm{~F}_{4} \mathrm{I}_{2}$ ligands surrounding a halide, containing a pair of $\mathrm{CI}^{\cdots} \mathrm{X}^{-}$ $\mathrm{XBs}$ [65] 

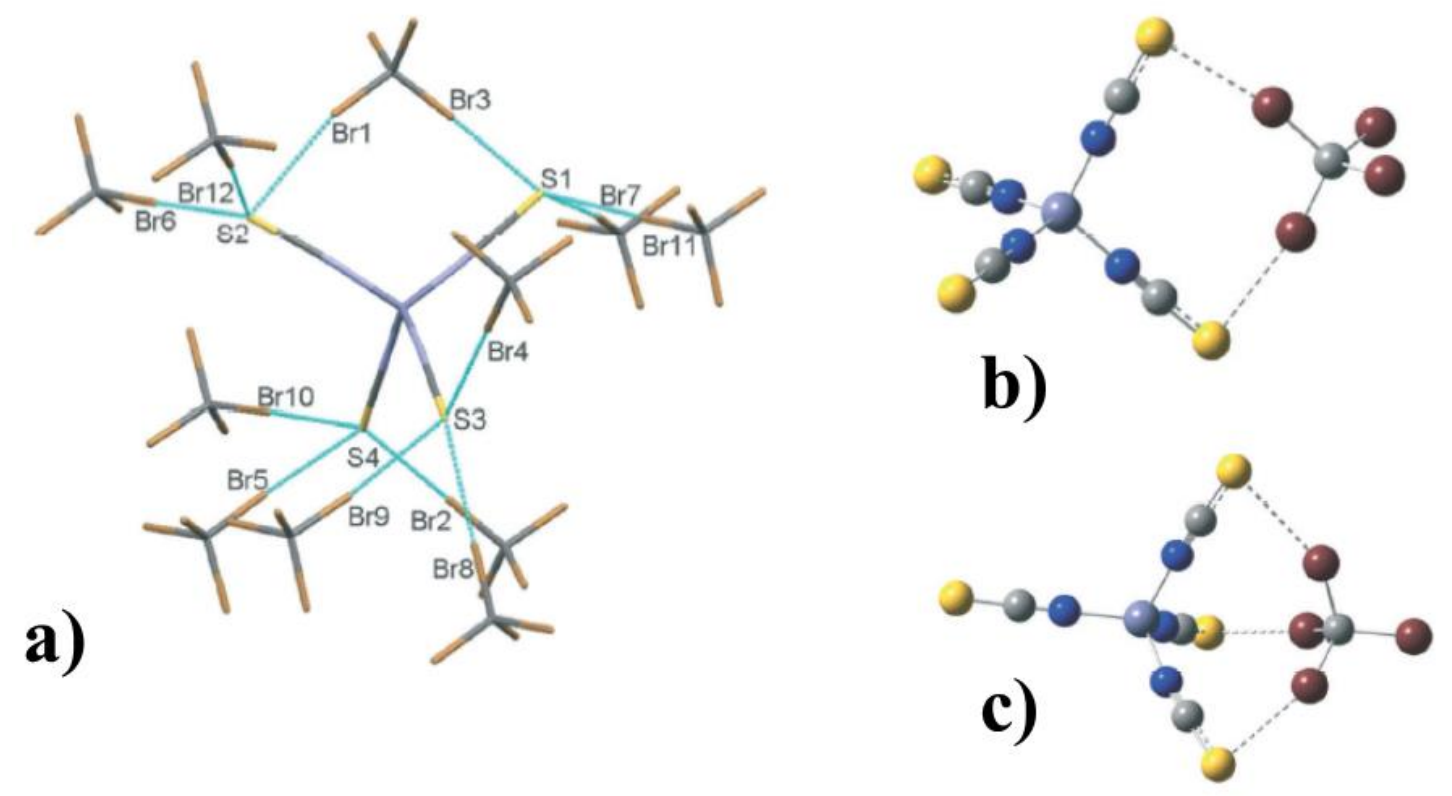

Fig. 8. Structure of a) $\left(\mathrm{Bu}_{4}\right)_{2}\left[\mathrm{Zn}(\mathrm{NCS})_{4}\right] \cdot 3 \mathrm{CBr}_{4}[66]$ showing halogen bonds in light blue. $\mathrm{Zn}$ atom is in center. Two (b) and three (c) point complexes studied by DFT calculations.
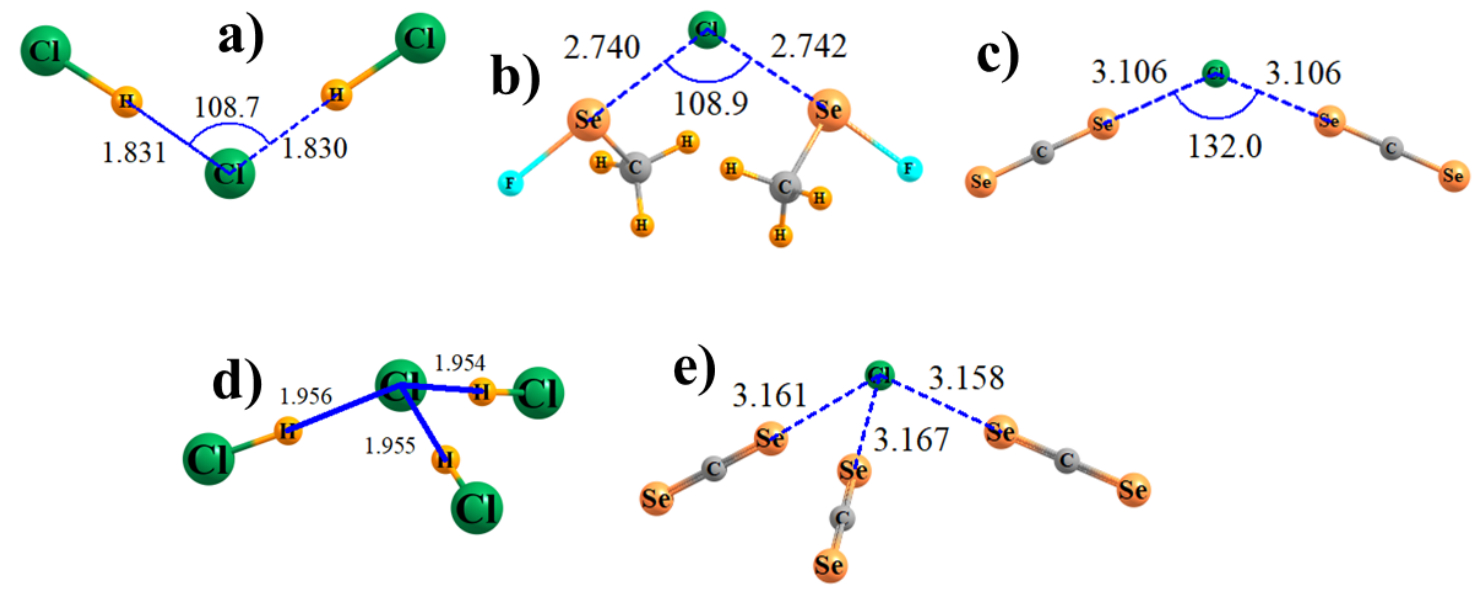

Fig. 9 Optimized geometries of $\mathrm{Cl}^{-}$surrounded by 2 and 3 ligands [27], that can engage in either HBs (a and d) or YBs (b,c,e). Distances in $\AA$. 


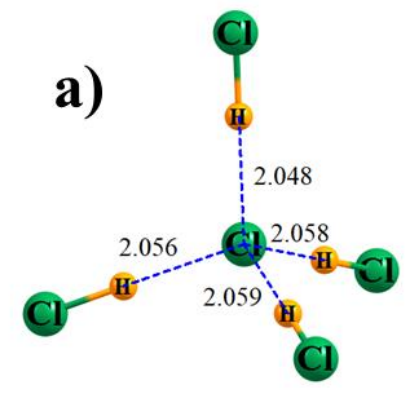

d)

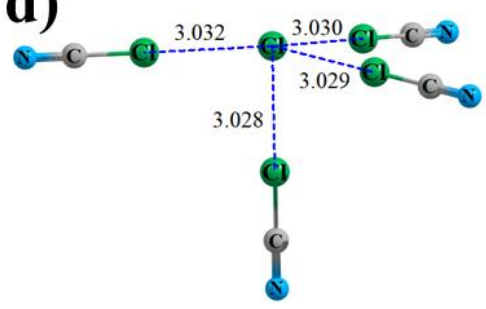

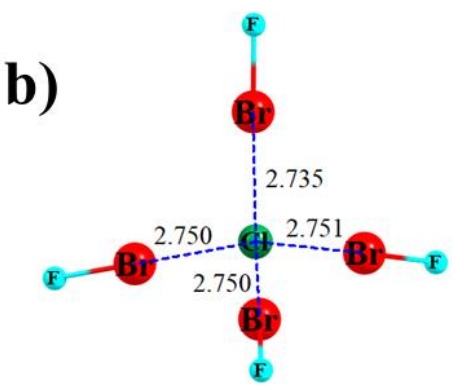

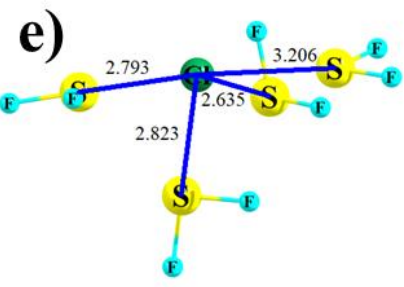

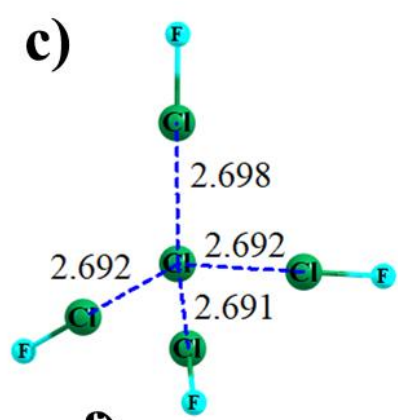

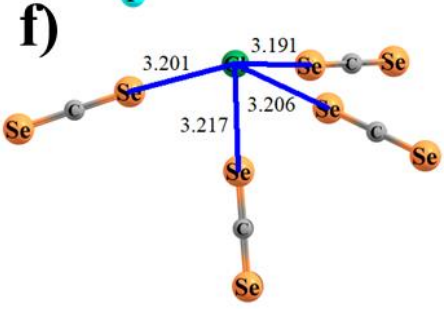

Fig. 10 Optimized geometries of $\mathrm{Cl}^{-}$surrounded by 4 ligands [27], that can engage in $\mathrm{HBs}$ (a), XBs $(b, c, d)$ or YBs $(e, f)$. Distances in $\AA$.

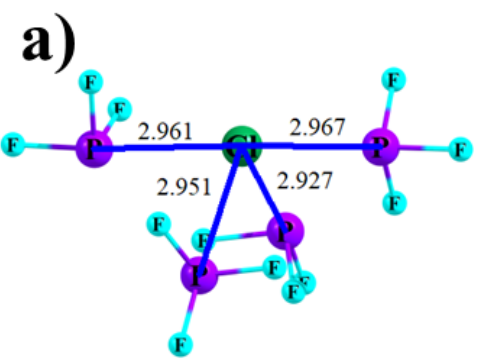

b)

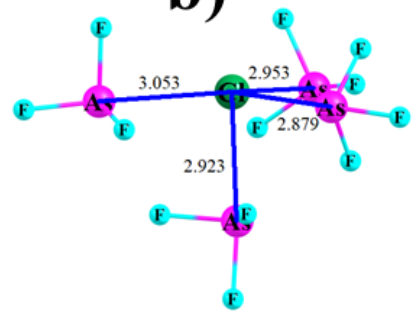

c)

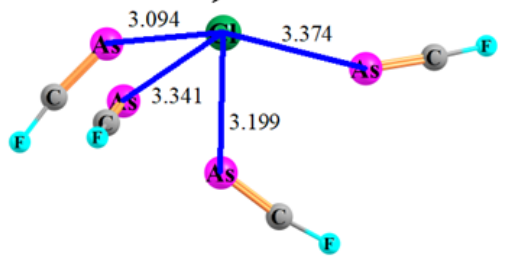

Fig. 11 Optimized geometries of $\mathrm{Cl}^{-}$surrounded by $4 \mathrm{ZB}$ ligands of a) $\mathrm{PF}_{3}$, b) $\mathrm{AsF}_{3}$, and c) As $\equiv$ CF [27]. Distances in $\AA$. 


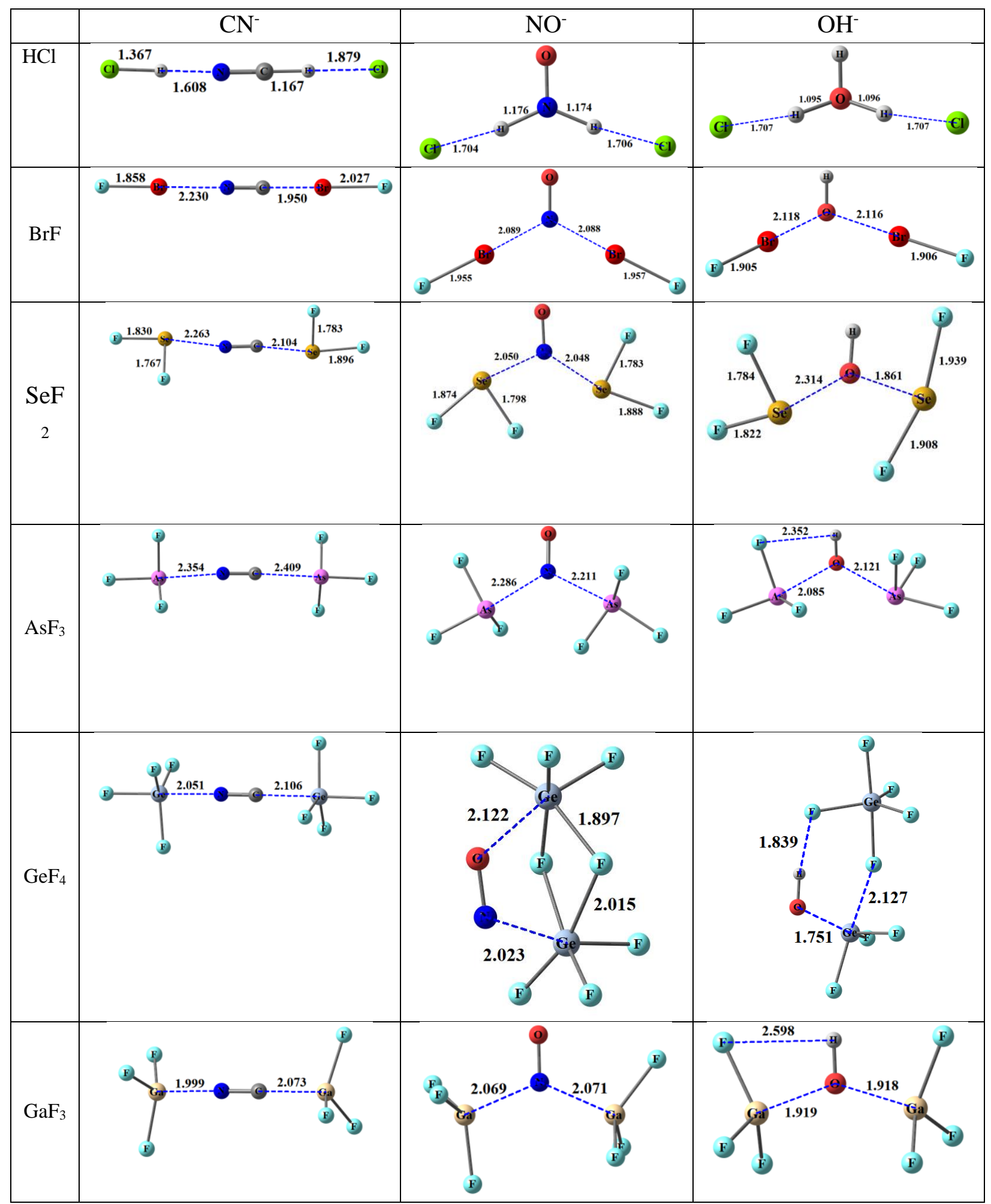

Fig. 12 Optimized geometries of $\mathrm{CN}^{-}, \mathrm{NO}^{-}$, and $\mathrm{OH}^{-}$surrounded by 2 ligands, as indicated in the first column. Distances in $\AA$ [28]. 


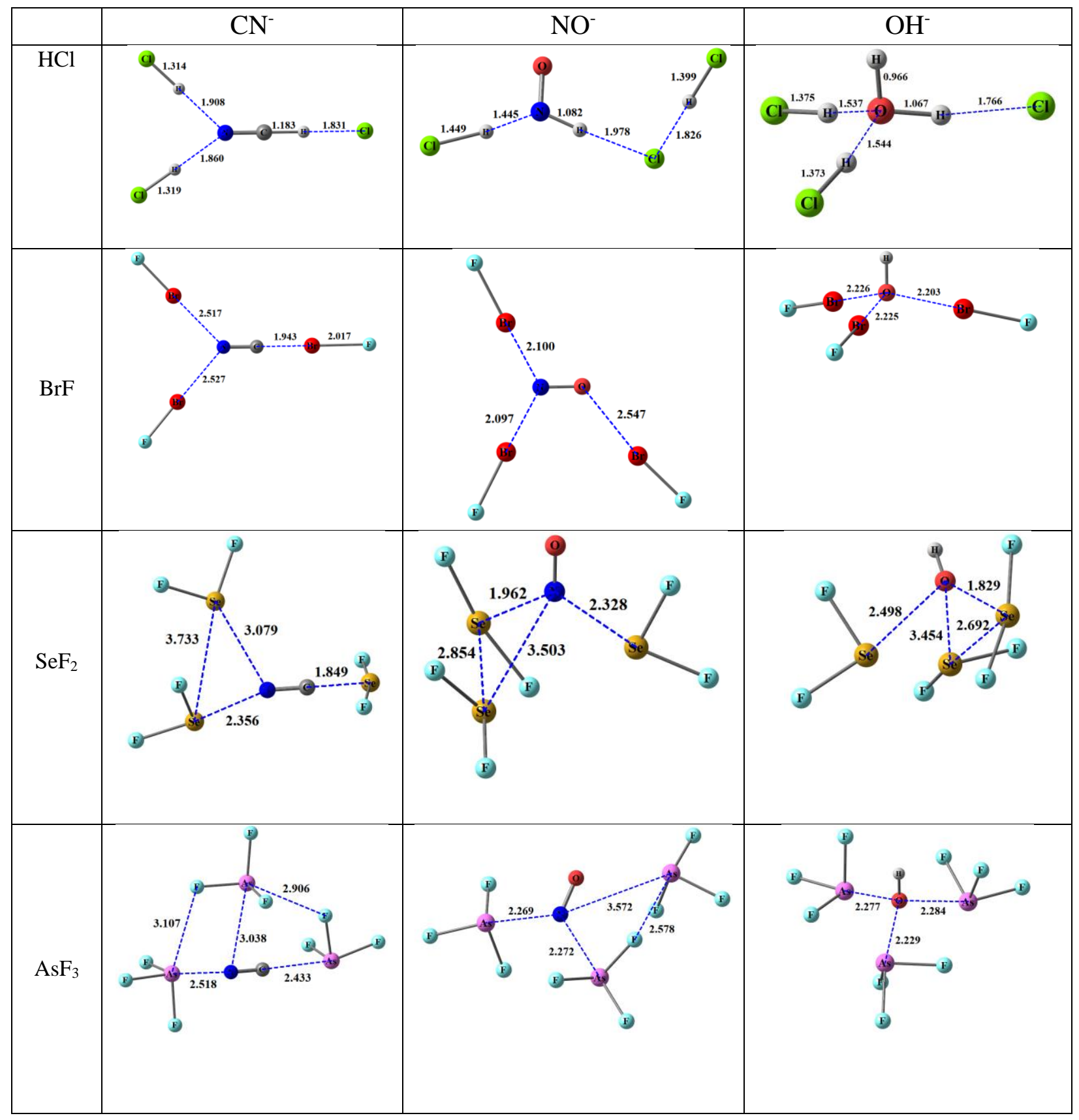




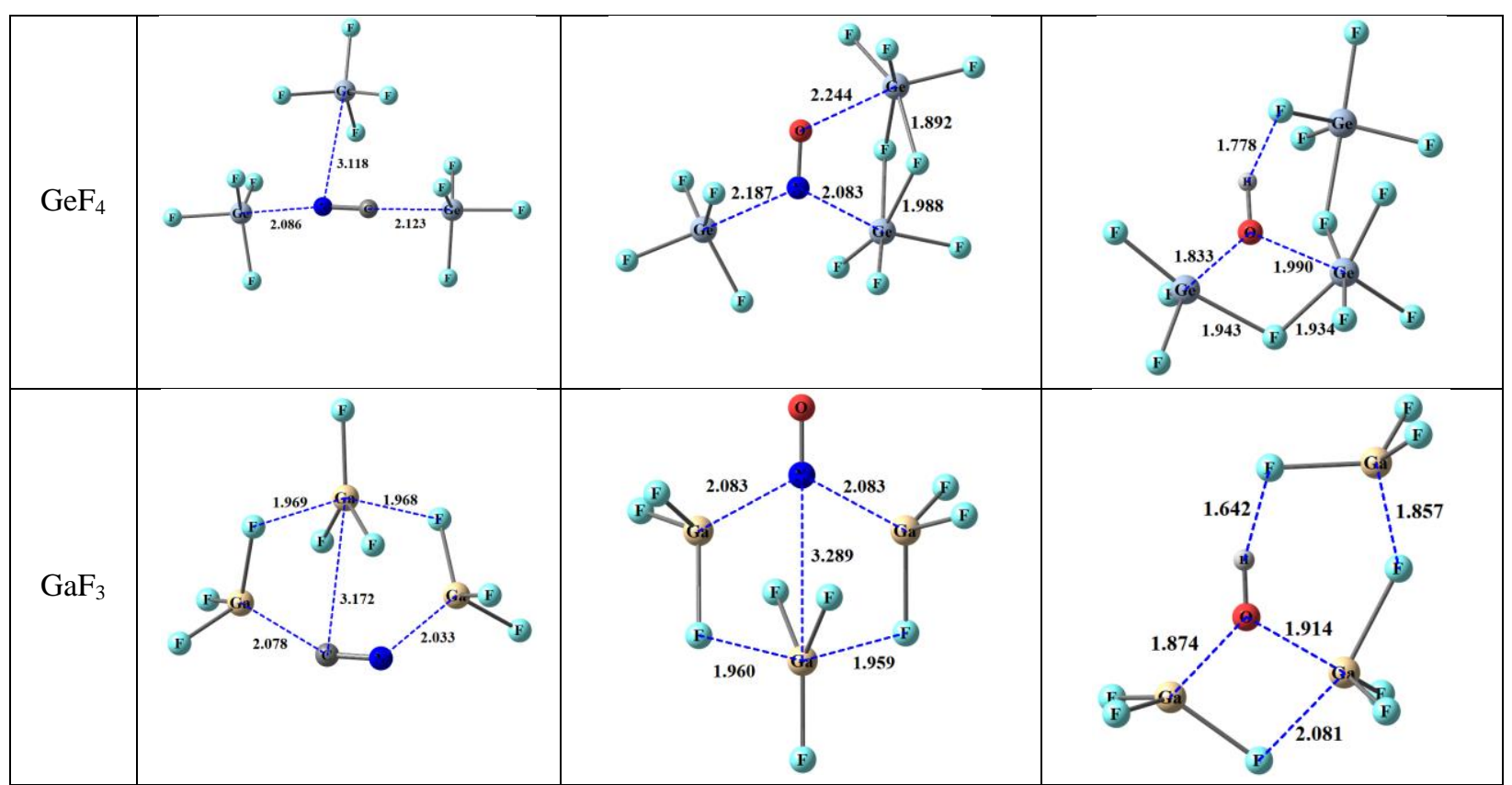

Fig. 13 Optimized geometries of $\mathrm{CN}^{-}, \mathrm{NO}^{-}$, and $\mathrm{OH}^{-}$surrounded by 3 ligands. Distances in $\AA$ [28].

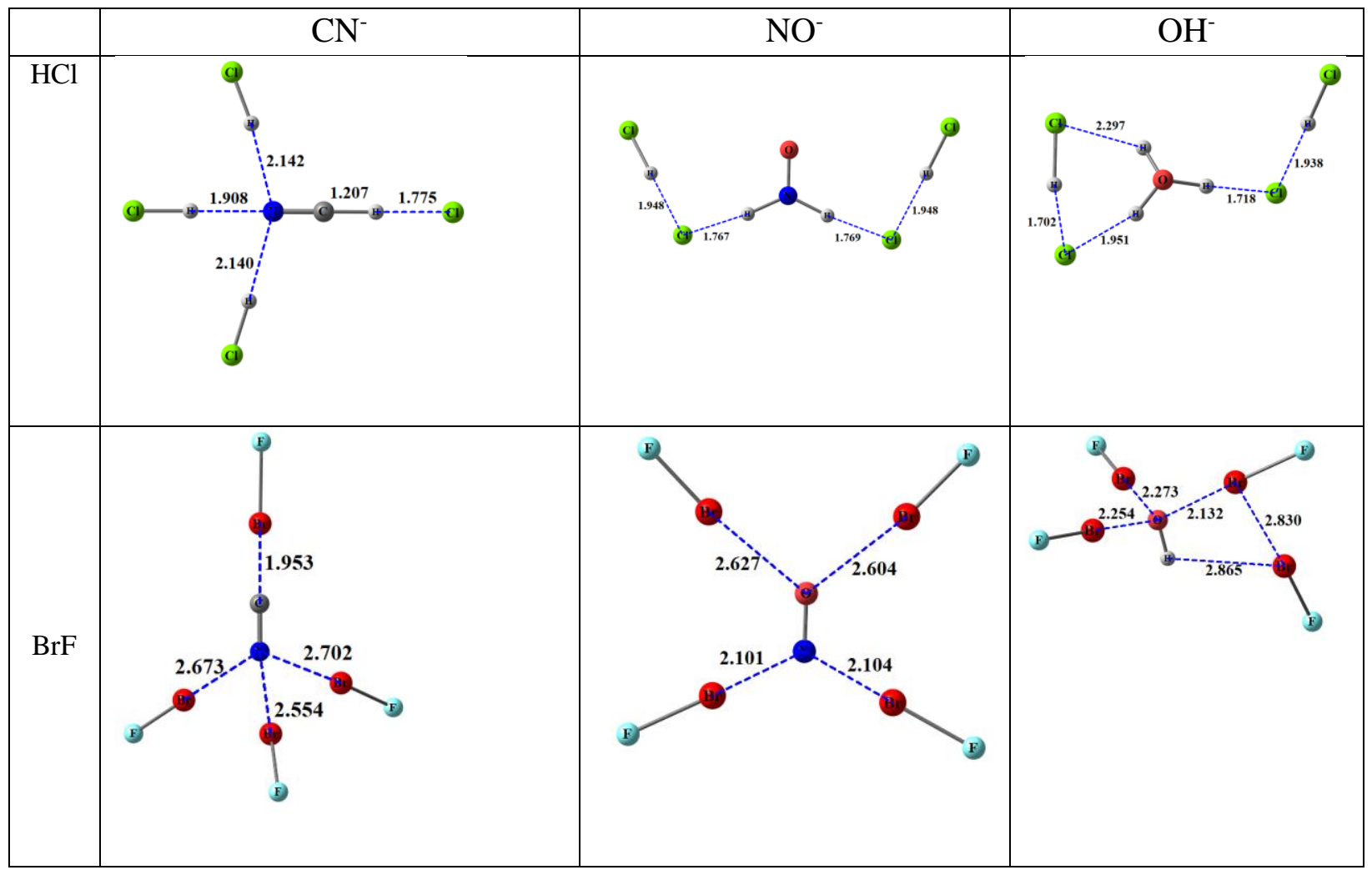




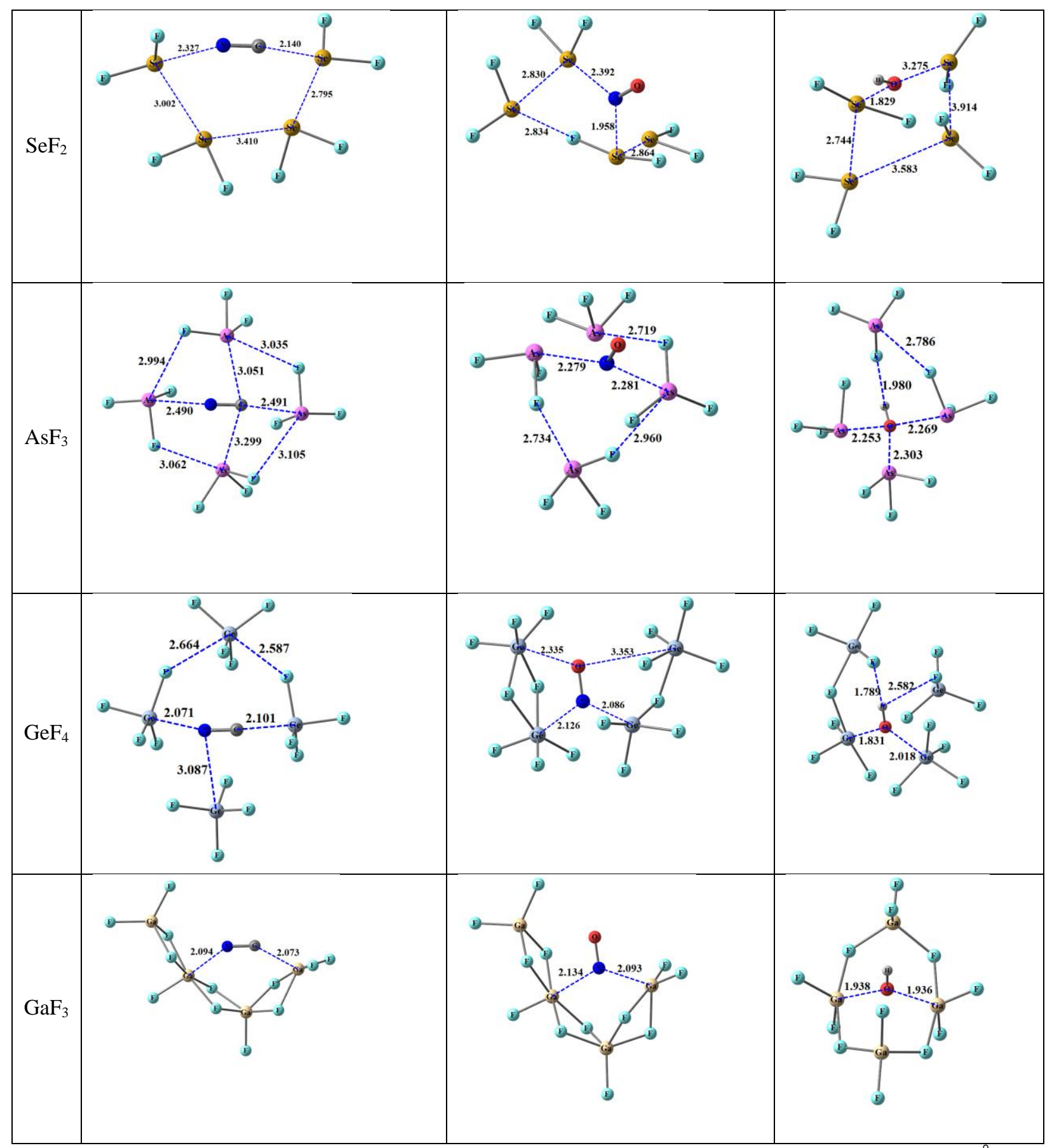

Fig. 14 Optimized geometries of $\mathrm{CN}^{-}, \mathrm{NO}^{-}$, and $\mathrm{OH}^{-}$surrounded by 4 ligands. Distances in $\AA$ [28]. 
a)

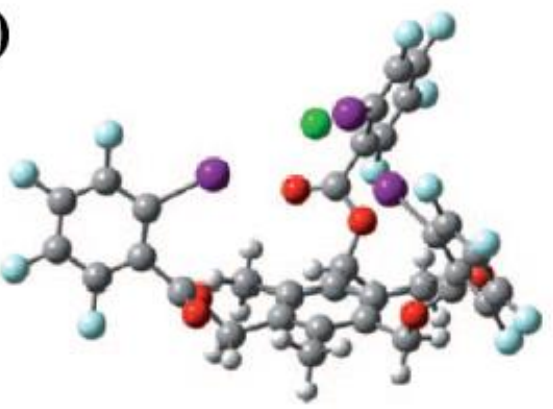

c)

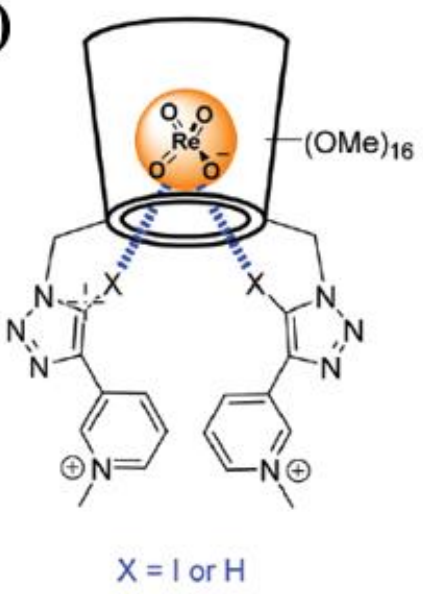

b)

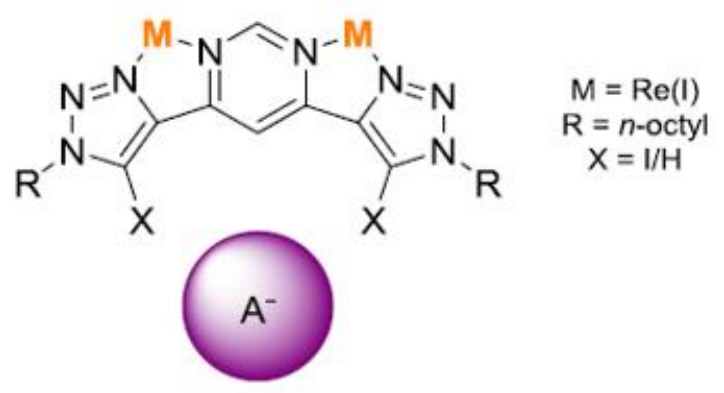

d)

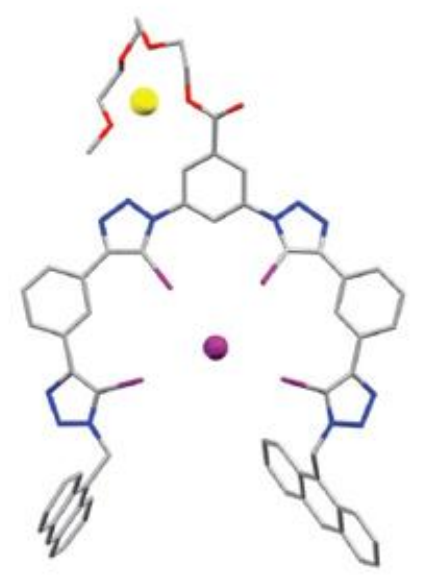

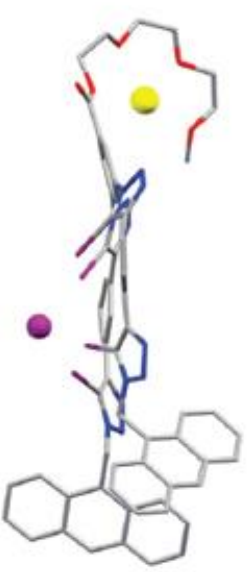

Fig. 15

a) Calculated structure of a) tripodal receptor bound to $\mathrm{Cl}^{-}$by a set of $\mathrm{C}-\mathrm{I} \cdots \mathrm{Cl}^{-} \mathrm{XBs}$ [68]. $\mathrm{Cl}$ is green and I atoms are purple.

b) placement of Re atoms into the bipodal receptor [77]

c) Schematic illustration of perrhenate anion bound by an $\alpha$-cyclodextrin unit via either HBs or XBs [79]

d) two views of tetradentate $\mathrm{XB}$ receptor [81] with $\mathrm{I}^{-}$. 
a)

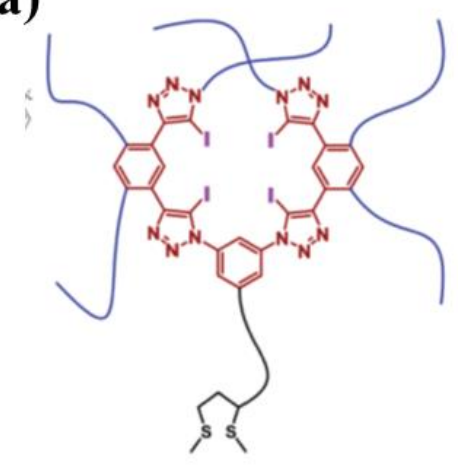

c)

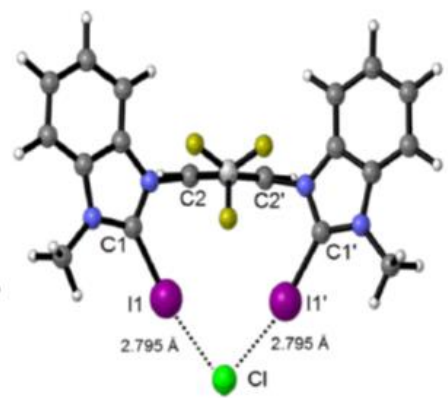

b)

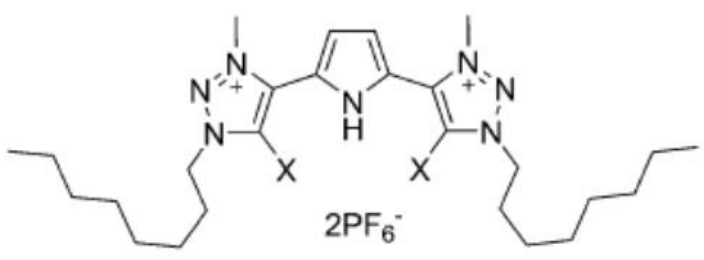

d)

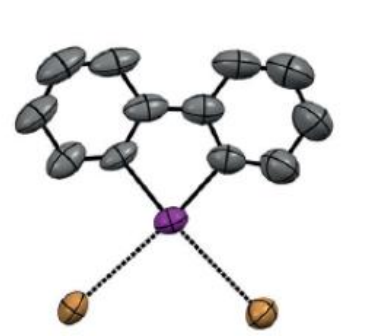

Fig. 16

a) Schematic drawing of a receptor which binds an anion with four XBs and several HBs [82]

b) pyrrole spacer surrounded by a pair of triazole species used to bind oxoanions [86]

c) structure of $\mathrm{Cl}^{-}$bound to a bipodal imidazolium-based I XB receptor [88],

d) binding of $\mathrm{Br}^{-}$(on the left) and $\mathrm{Cl}^{-}$(right) through I atom in the $\mathrm{XB}$ receptor generated by Heinen et al [90]. 

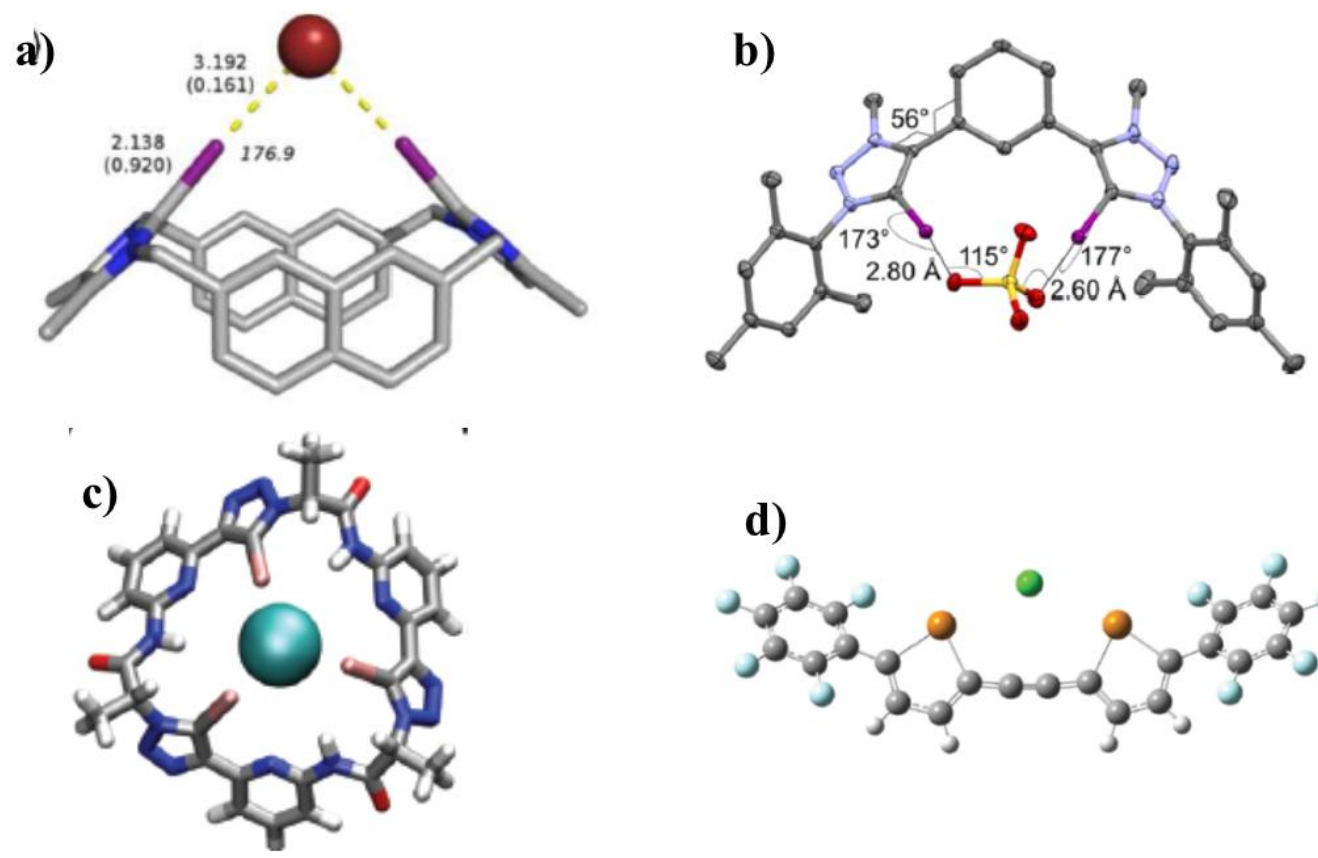

d)

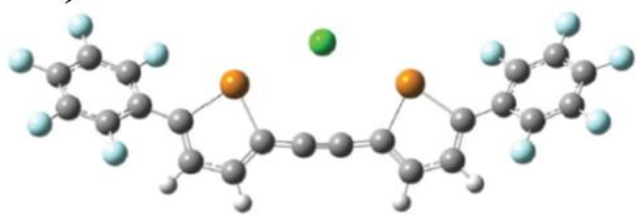

Fig. 17 a) A receptor [92] which binds the halide through I-substituted imidazoliums.

b) the binding of sulfate to a bipodal receptor based on iodotriazolium [94],

c) $\mathrm{Cl}^{-}$anion bound to a pseudocyclopeptide containing three 5-I-triazole units [101]

d) a bipodal pair of Se YBs binds to a $\mathrm{Cl}^{-}[103]$

a)

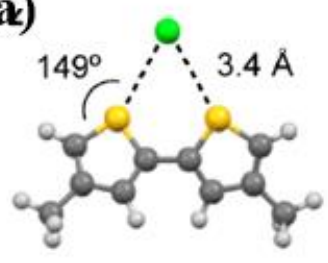

c)
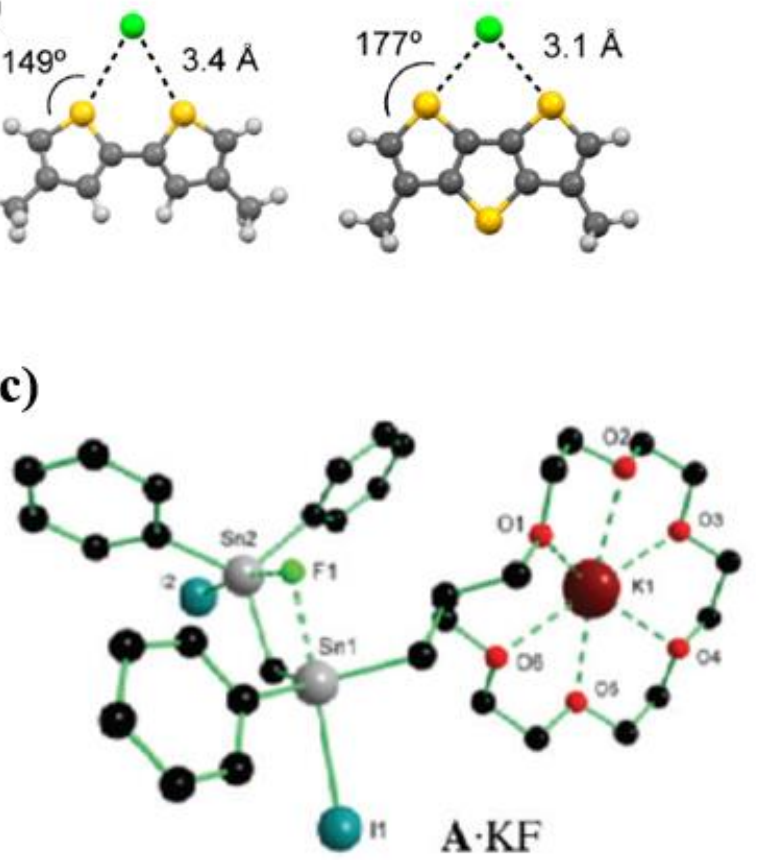
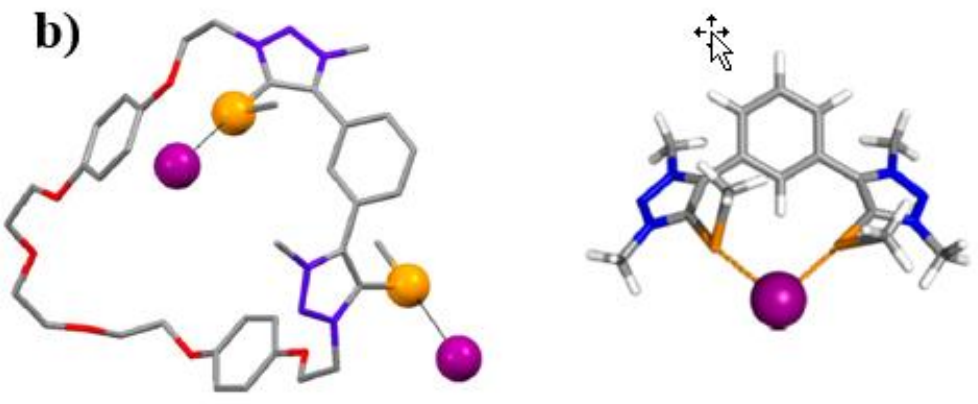

Fig. 18

a) S-containing bipodal halide receptors studied by Benz et al [104].

b) $\mathrm{Se}^{\cdots} \mathrm{I}^{-}$YBs hold the iodide anion [105]. 
c) Manner of binding of $\mathrm{KF}$ to $\mathrm{Ph}_{2} \mathrm{FSnCH}{ }_{2} \mathrm{SnFPh}-\mathrm{CH}_{2}$ connected to 19-crown-6 [109],
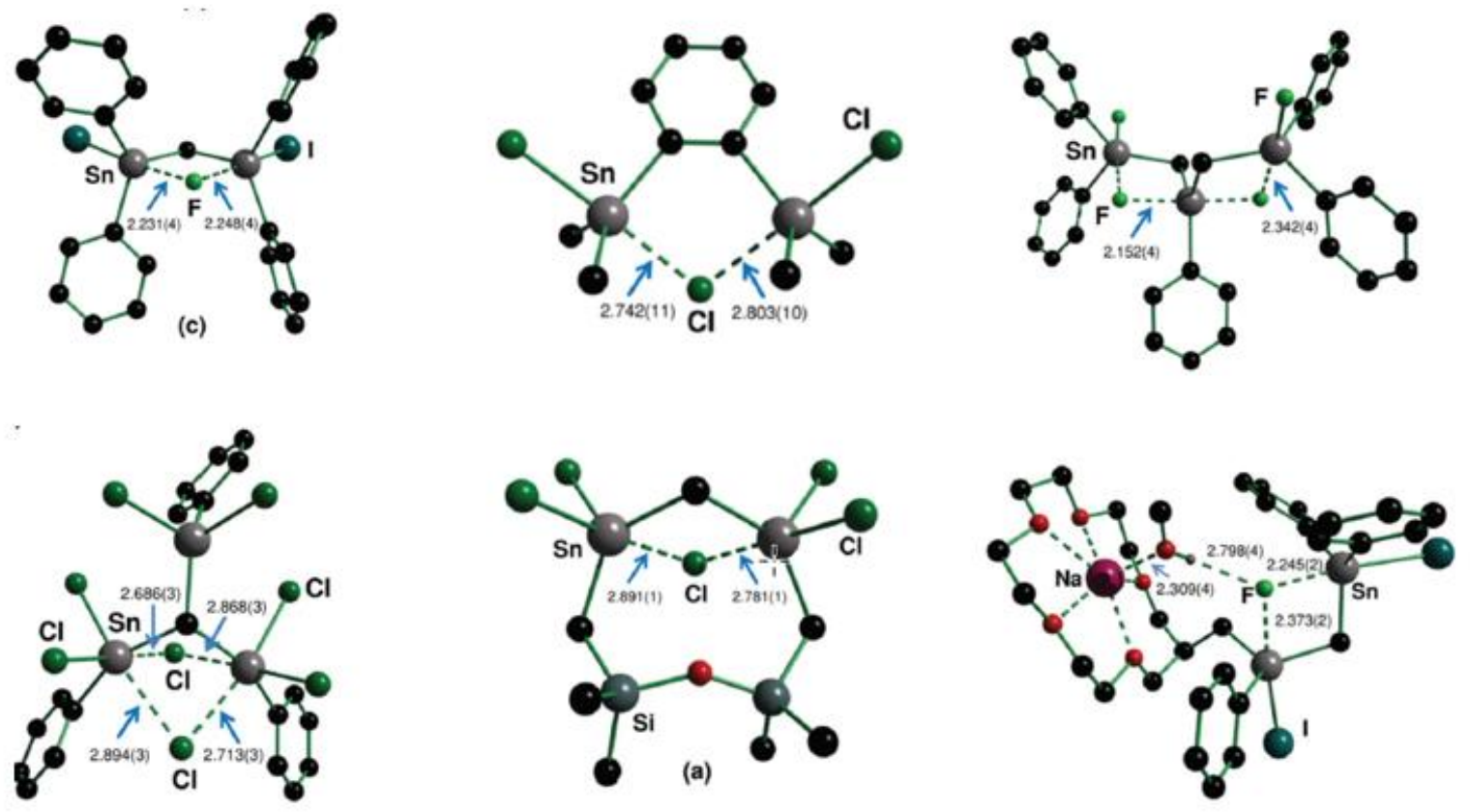

Fig. 19 A variety of anion receptors based on Sn tetrel bonds [110].<smiles>[Y]c1[nH]nnc1-c1cncc(-c2nn[nH]c2[2H])c1[1H]</smiles>

neutral BTP<smiles>[Y]c1[nH]nnc1-c1c[n+](C)cc(-c2nn[nH]c2[1H])c1[2H]</smiles>

cation $\mathrm{BTP}^{+}$<smiles></smiles>

dication $\mathrm{BTP}^{+2}$

Fig. 20 Schematic diagrams of model receptors incorporating Bis-triazole-pyridine (BTP) [117] with various charges. 

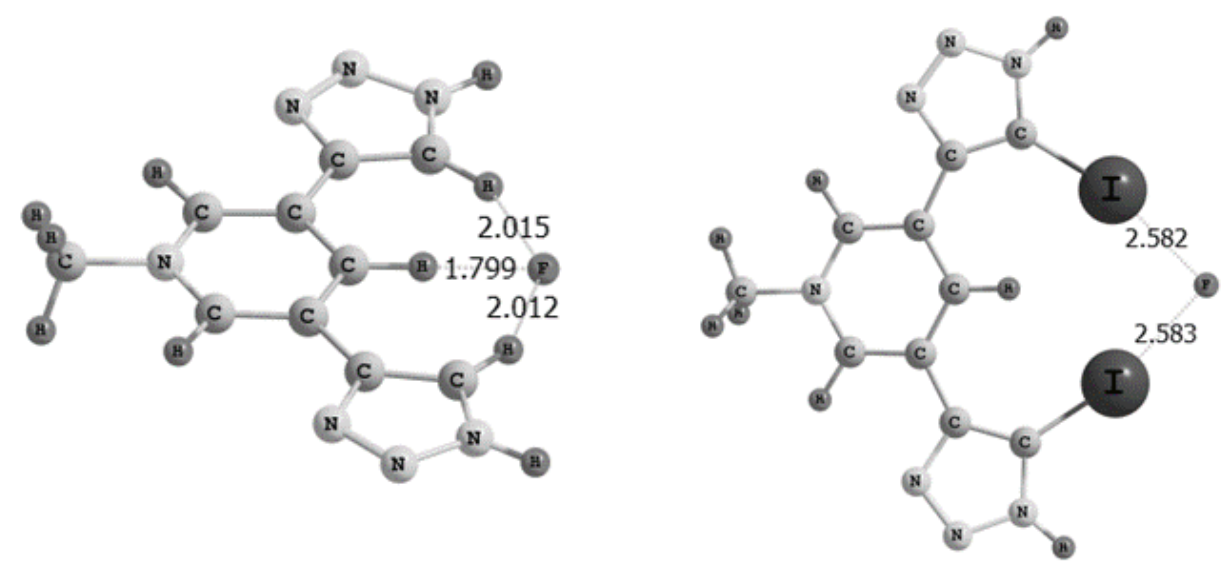

Fig. 21 Structures of two BTP receptors bound to fluoride [117]

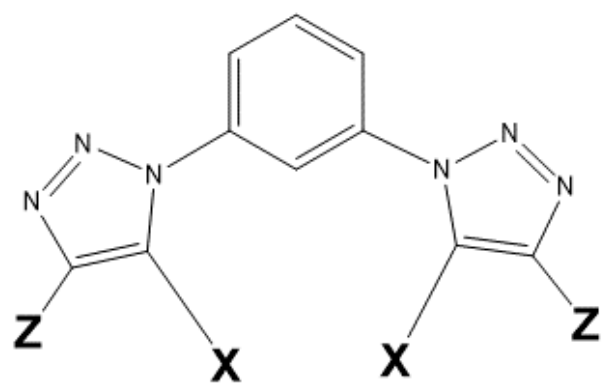

I, neutral

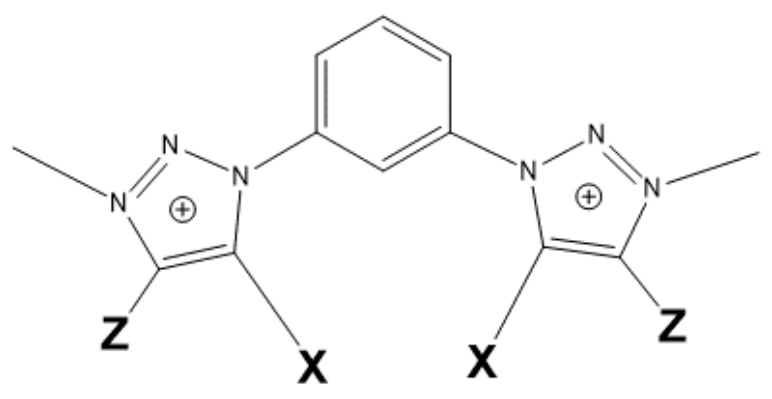

II, dication

$$
\mathbf{X}=\mathbf{H}, \mathbf{I}
$$

$\mathrm{Z}=\mathrm{H}, \mathrm{Me}, \mathrm{OH}, \mathrm{OMe}, \mathrm{NH}_{2}, \mathrm{NO}_{2}, \mathrm{CHO}, \mathrm{COOH}, \mathrm{COMe}, \mathrm{CN}, \mathrm{CF}_{3}$

Fig. 22 Model receptors tested, of charges 0 and +2 [118], with a variety of substituents Z. 


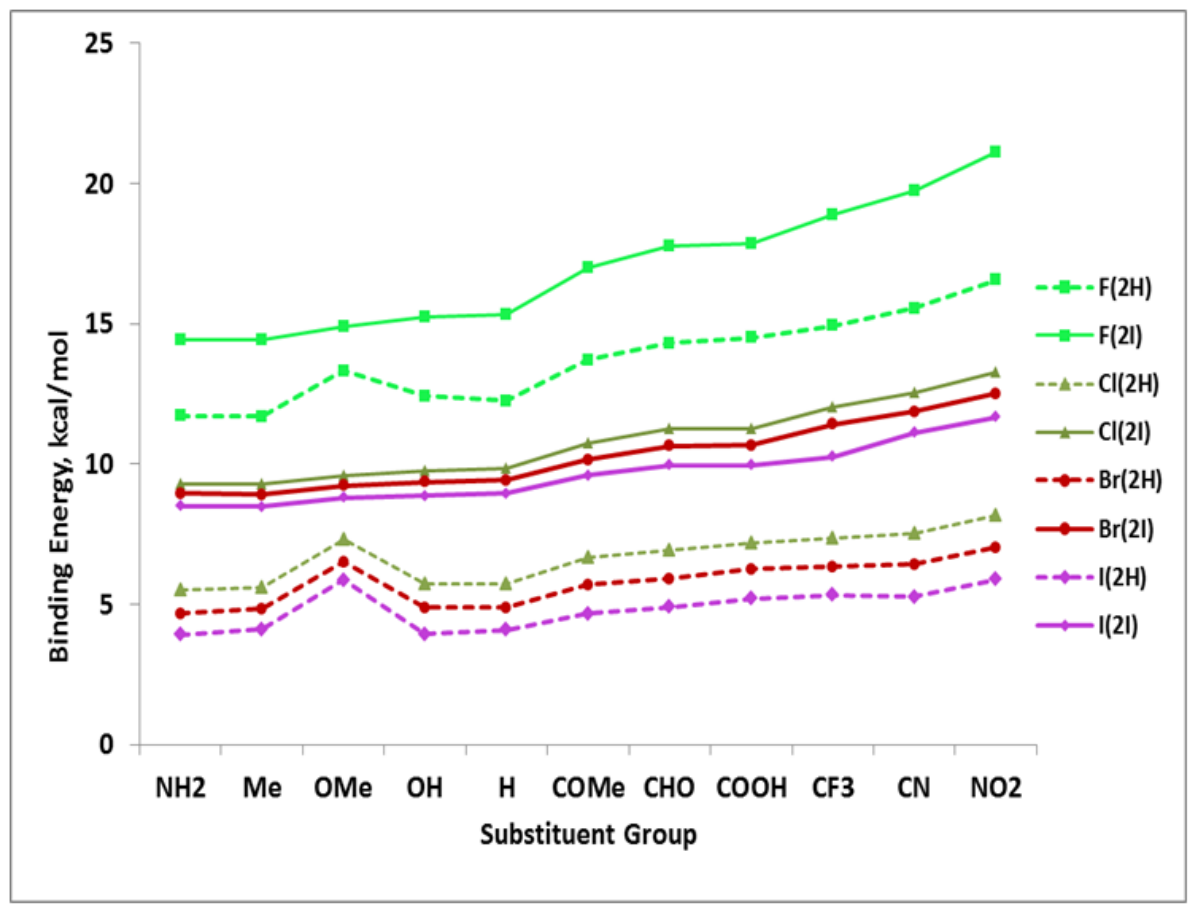

Fig. 23 Binding energy calculated [118] in terms of substituent. Halide being bound shown as $\mathrm{F}^{-}$(green), $\mathrm{Cl}^{-}$(olive), $\mathrm{Br}^{-}$(red), or I' (purple). Broken curves indicate $\mathrm{HB}$ receptor, and solid curves refer to $\mathrm{XB}$. 

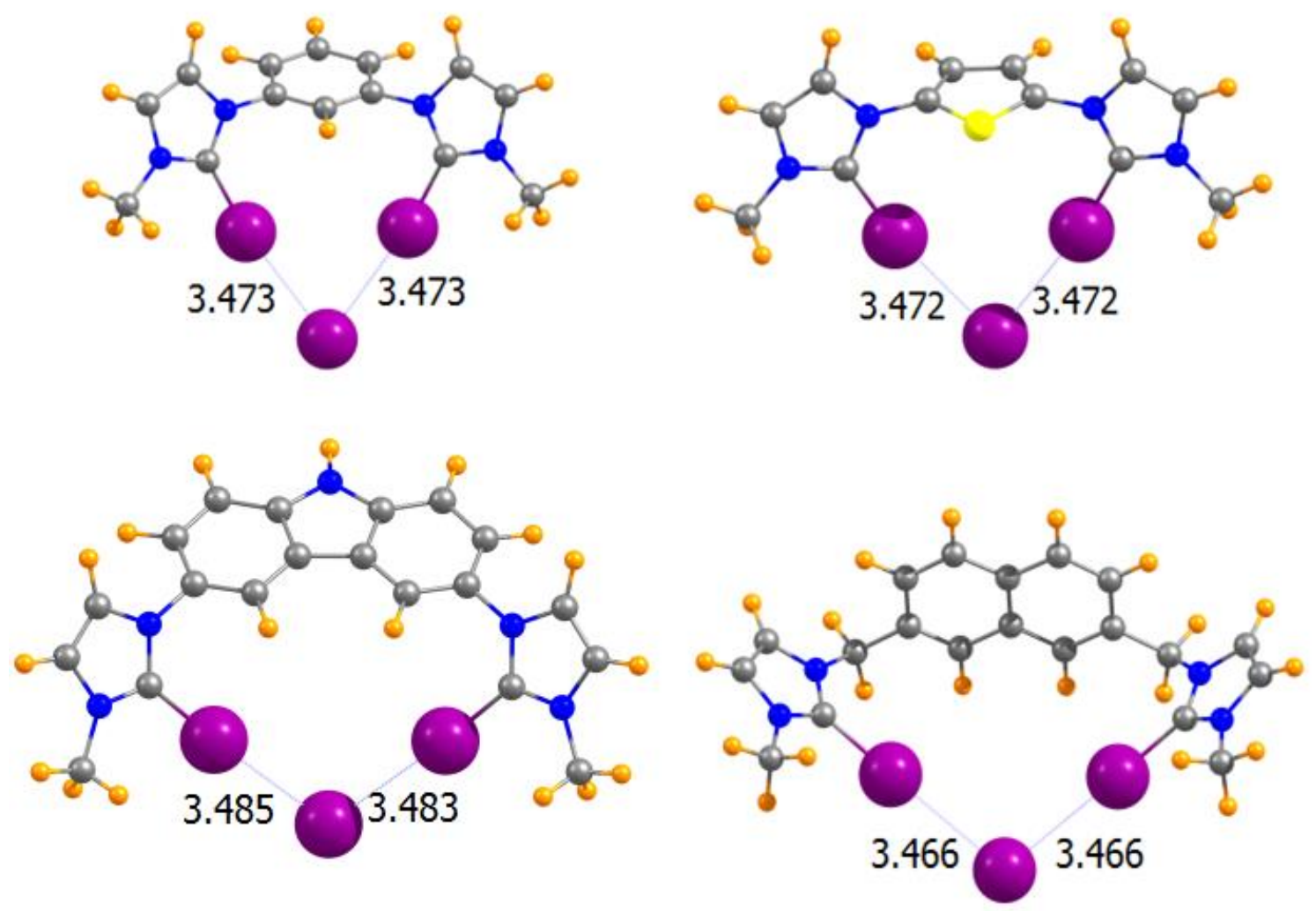

Fig. 24 Receptors that differ in the spacer group connecting the two I-substituted imidazoliums [119]
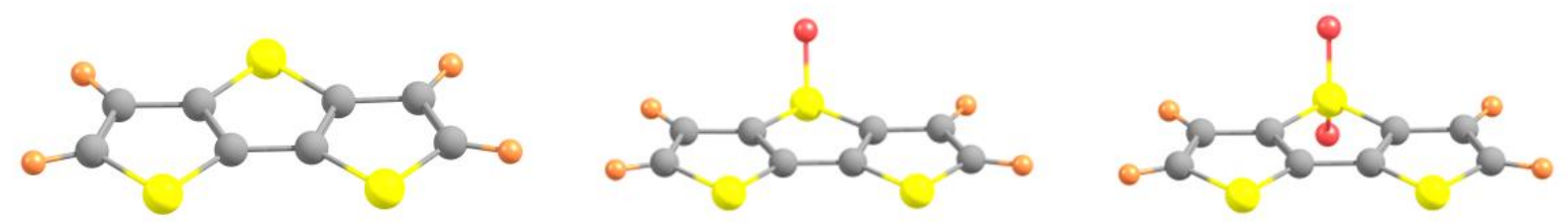

Fig. 25 Chalcogen-bonding receptors based on dithieno thiophene framework with $\mathrm{S}$ atoms engaging in YBs with a halide [120] 


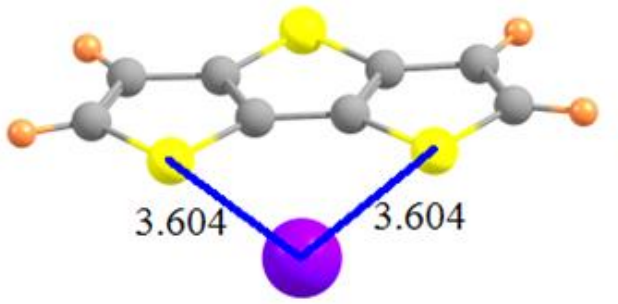

a) $\mathrm{S}-\mathrm{I}^{-}$

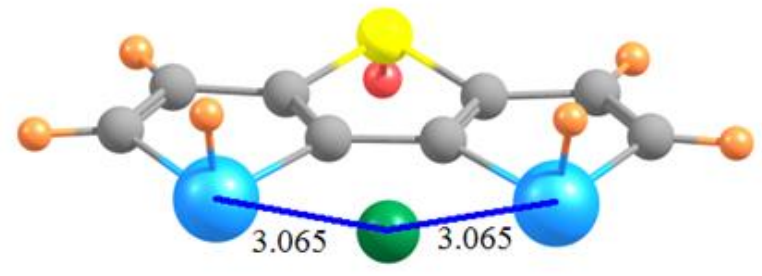

c) $\mathrm{As}--\mathrm{Cl}^{-}$

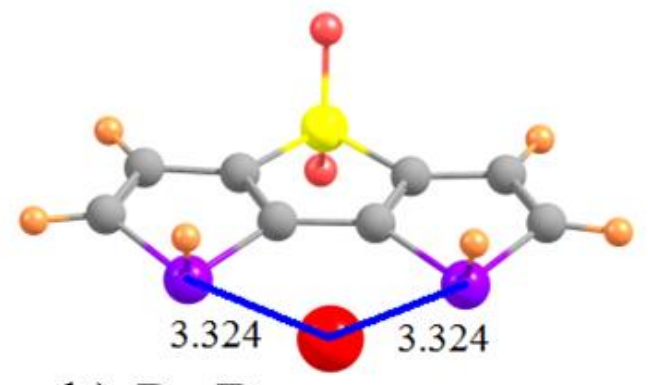

b) $\mathrm{P}--\mathrm{Br}$

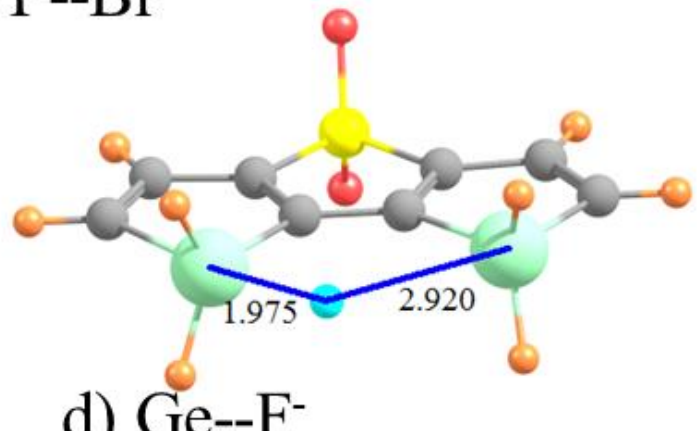

d) $\mathrm{Ge}-\mathrm{F}^{-}$

Fig. 26 Selected geometries binding halides to variant of dithieno thiophene receptor [120].

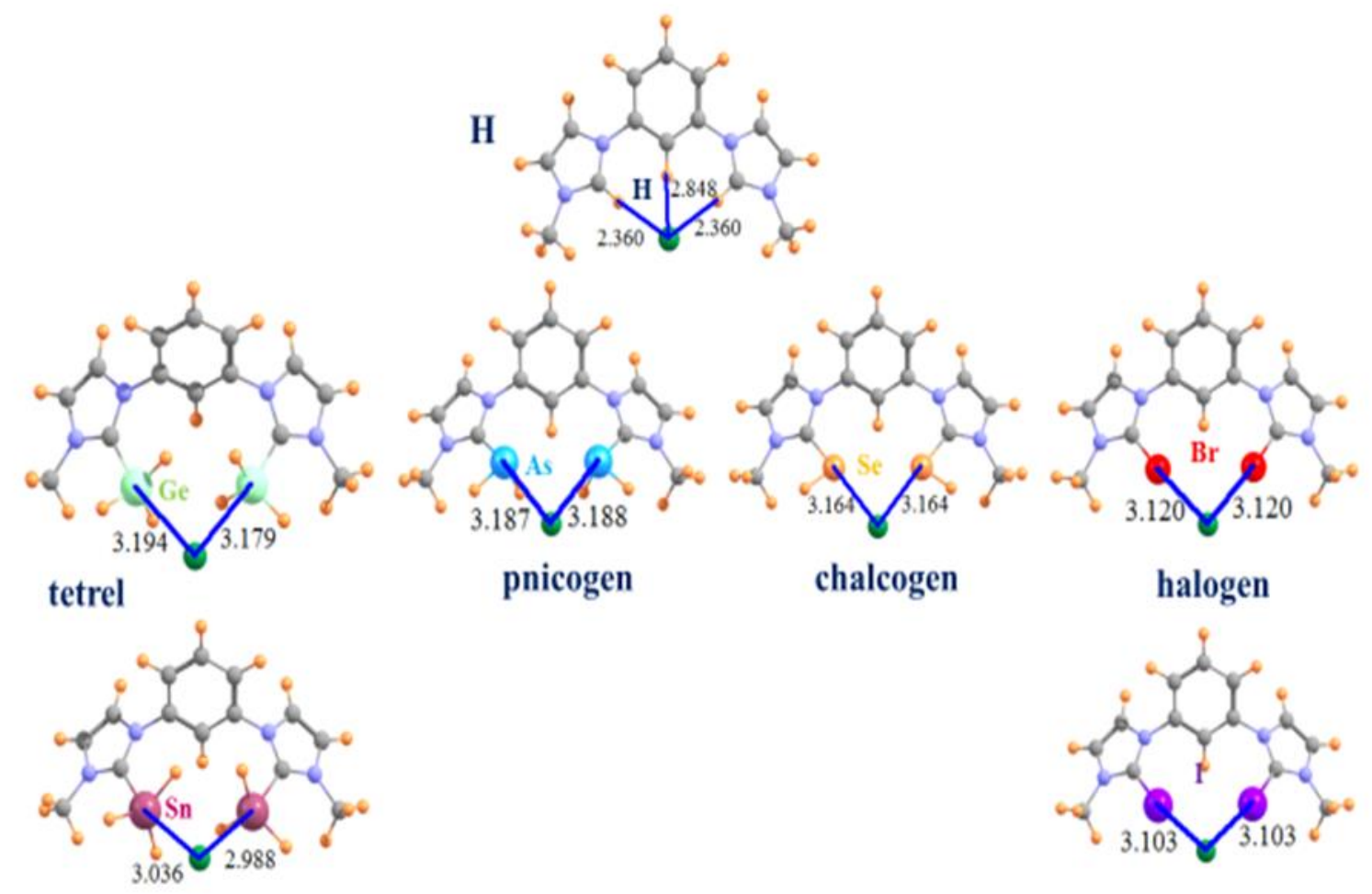

Fig. 27 Receptors based on four types of noncovalent bonding, shown bound to $\mathrm{Cl}^{-}$[123] 

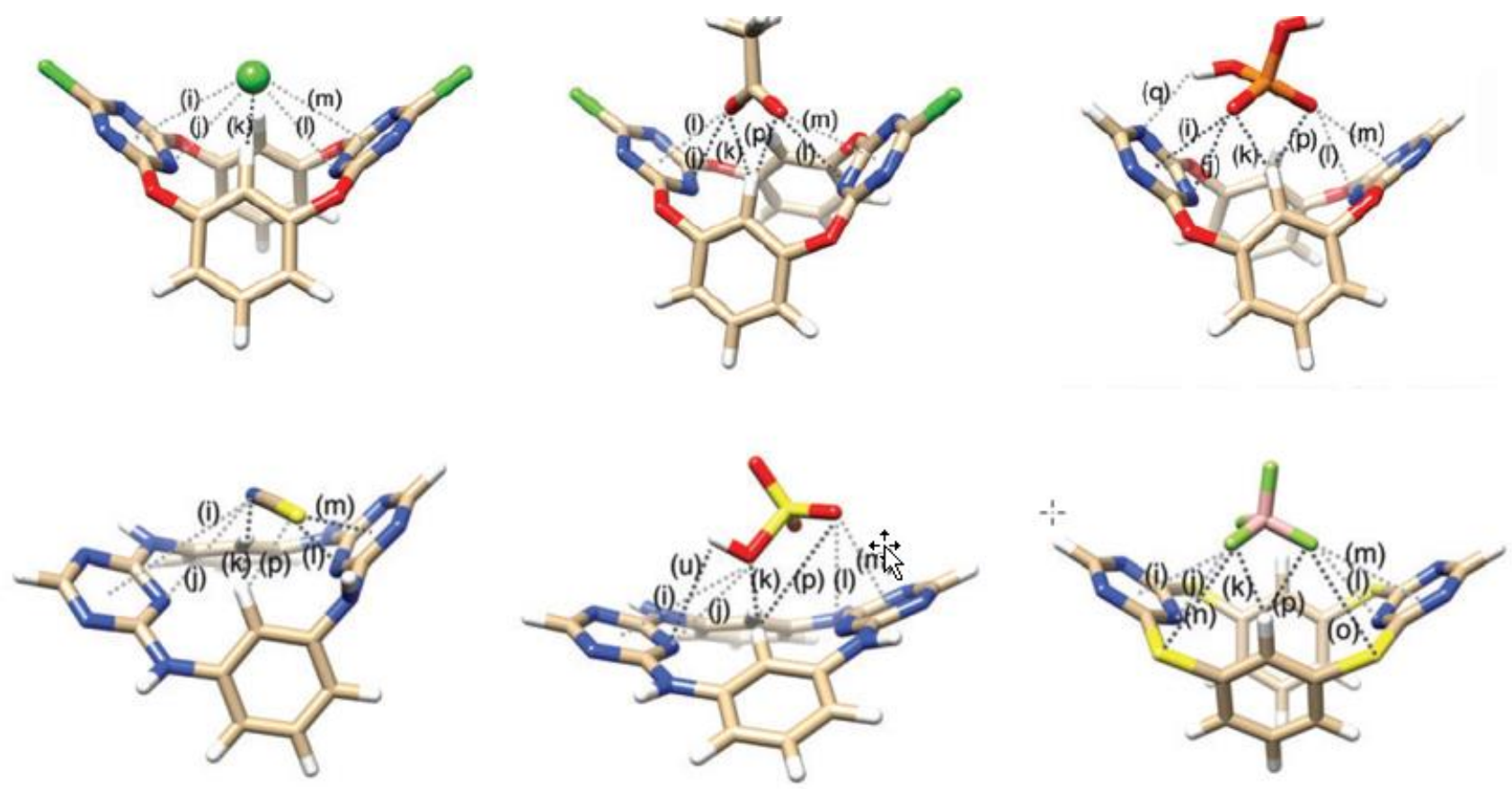

Fig. 28 Structures of calixarenes bound [124] to $\mathrm{Cl}^{-}$, acetate, $\mathrm{H}_{2} \mathrm{PO}_{4}^{-}, \mathrm{NCS}^{-}, \mathrm{HSO}_{4}^{-}$and $\mathrm{BF}_{4}^{-}$. 